Department of Biochemistry

Faculty of Medicine

Universidad Autónoma de Madrid

\title{
ONSET OF CELL DIFFERENTIATION AND \\ FIRST LINEAGE DECISIONS IN THE MOUSE EMBRYO \\ THROUGH THE NOTCH PATHWAY
}

Sergio Menchero Fernández. BSc Biology

Doctoral thesis directed by Dr. Miguel Manzanares Fourcade CNIC, Madrid 2019 

I hereby certify that SERGIO MENCHERO FERNANDEZ has carried out the experimental work leading to his $\mathrm{PhD}$ thesis entitled "Onset of cell differentiation and first lineage decisions in the mouse embryo through the Notch pathway" under my supervision at the Centro Nacional de Investigaciones Cardiovasculares-CNIC in Madrid.

I also declare that the work presented is novel and of great importance in the field, and of sufficient quality to merit to be presented in order to obtain a PhD degree by the Universidad Autónoma de Madrid.

Madrid, 22nd October 2018

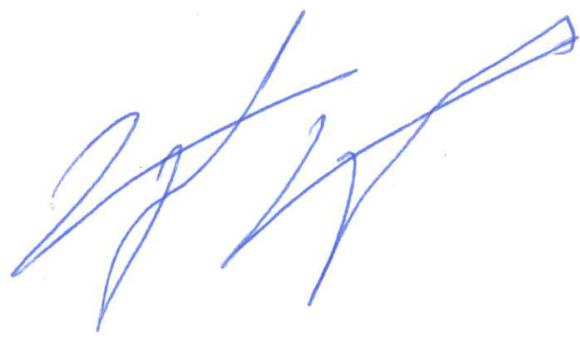

Miguel Manzanares

Centro Nacional de Investigaciones Cardiovasculares-CNIC

Melchor Fernández Almagro, 3

28029 Madrid, Spain

tel: (34) 914531200

fax: (34) 914531304

mmanzanares@cnic.es

http://www.cnic.es/en/desarrollo/genomica 



\section{External report for the PhD thesis of Sergio Menchero Fernandez}

The question of interest pursued in this project relates to one of the most fundamental processes of mammalian development: how the founder lineages for the foetus and placenta are initially segregated. The Introduction provides ample evidence of extensive background reading and a genuine understanding of the current state of knowledge. It is thoughtfully illustrated throughout with figures that are largely original. Reflecting the state of current interest in the research questions being addressed, the candidate has already published a review article summarizing the mechanisms of early mouse development. In preparation for the results section, the objectives are clearly articulated and provide a strong motivation for the work. The nature of the interaction of two embryonic pathways, Notch and Hippo that leads to specification of Cdx2 expression in the trophectoderm is explored in the first experimental chapter. Using embryos carrying various genetic modifications in the relevant pathways a detailed quantitative study of protein distribution was performed. The experimental design is sound and the images and figures are of excellent quality. A series of developmental stages from early cleavage until blastocyst is used in order to pinpoint temporally the requirement for the components of the two signaling pathways for trophectoderm specification. Embryos carrying multiple fluorescent reporters were also employed to track the activity of specific signaling pathways. The analysis of cell properties in the context of position within the embryo required the use of sophisticated tools; these are well explained and clearly presented. Molecular profiling and bioinformatic analysis were also performed comparing various mutant and unmanipulated embryos. This led to the identification of candidate target genes of Notch in the context of preimplantation mouse development. Two in particular (Tbx3 and Tle4) were affected by treatment of embryos with Notch inhibitor ex vivo. Specific regions of these associated with chromatin accessibility were mutated in embryos to test their requirement for Notch signaling. Only the deletion in Tle4 appears to be necessary for functional Notch signaling. In the next set of experiments the role of Notch signaling in the context of exit from naïve pluripotency (differentiation) was explored. Embryonic stem cells as well as early embryos were utilized to address this question. A role for Notch signaling in allowing transition from an unspecified to a committed state was therefore identified in these two contexts.

Overall, this thesis began with a set of important questions in the context of mammalian development and cell differentiation. Diverse experimental techniques and analyses were engaged, as required by the arising questions, indicating a high level of talent and dedication to the project. The results are carefully and engagingly presented and each finding thoughtfully discussed. It has been a pleasure and an education to read. Most importantly, the work presented provides novel and important scientific advances. There is no question that Sergio deserves to be awarded a $\mathrm{PhD}$ and I look forward to following his future progress.

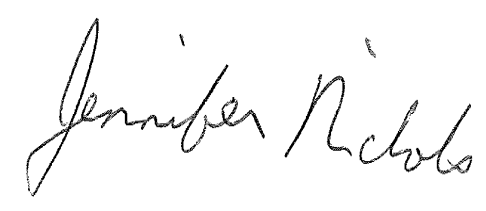

Jennifer Nichols

$24^{\text {th }}$ October 2018 



\title{
Imperial College London
}

\author{
British Heart Foundation Centre for \\ Research Excellence \\ National Heart and Lung Institute \\ Imperial College London \\ Hammersmith Hospital Campus \\ Du Cane Road \\ London, W12 ONN \\ United Kingdom \\ Tel: +44 (0)207594 1915 \\ Email: Tristan.rodriguez@ic.ac.uk
}

24 October 2018

To Whom It May Concern,

\section{RE: Report for the thesis entitled "Onset of cell differentiation and first lineage decisions in the mouse embryo through the Notch pathway" by Sergio Menchero Fernández.}

The first lineage choice in the mammalian embryo takes place before implantation. From an undifferentiated group of cells, the trophectoderm and the inner cell mass arise. This thesis examines the molecular mechanisms governing this important decision in the embryo development.

The introduction provides with a compendium of the previous literature in the field. It contains all the important experiments done previously to this work and covers the different signaling pathways that control the differentiation process. Overall, it offers a clear and comprehensive overview of the subject.

The results describe the experiments performed by the candidate towards the understanding of the regulation of the first lineage decision in the mouse embryo. Sergio has studied the regulation of trophectoderm specification taking $C d x 2$ as a marker of trophectoderm cells. To that end, he has focused in the earliest stages in which $C d x 2$ becomes expressed: the early morula. In that stage, by using genetic loss of function models, he discovered that both Notch and Hippo signaling pathways are important for the expression of $C d x 2$ but they do not act in the same time window. By inhibiting either Notch or Hippo pathway, he determined that at early stages is Notch that regulates the onset of $C d x 2$ expression and determines the position of the cells in the blastocyst, while at later stages is the Hippo pathway that takes over and 
maintains $C d x 2$ expression. In the second part of the results section, by means of RNAseq analysis in morulae lacking the Notch pathway effector, $R b p j$, he unveiled specific targets of the Notch pathway at early stages: Tle 4 and Tbx3, which are important for the exit of pluripotency.

This work has deep ramification in the functional role of Notch prior to the establishment of the first lineages in the embryo, as Sergio has established that Notch expression triggers differentiation in the early morula through the activation of specific targets.

The discussion not only helps understanding the whole project, but also its implications. It proposes a model in which one pathway is not enough to define the first lineage choice in the embryo. Instead, it is needed an interplay of two different pathways, one for the onset and other for the maintenance of the trophectoderm lineage.

This is a unique thesis that carries new ideas into the field of early embryo differentiation and stem cells. The implications of this work in future projects in this and other fields make this an invaluable effort. For all this, Sergio deserves to be awarded a PhD.

We thank you for your consideration.

With best wishes,

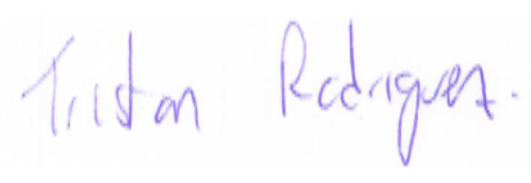

Tristan Rodriguez, PhD 
A mi familia.

A los que hacen que todo sume. 

Siete... Han pasado siete años desde que puse un pie por primera vez en este centro, y nunca pensé que hoy estaría escribiendo esto. Solo buscaba un laboratorio donde hacer prácticas para la universidad, pero me lie. Acabé apuntándome a un máster y dos años después estaba matriculándome en el programa de doctorado. No tengo ninguna duda de que la "culpa" de que hoy esté aquí es haber caído en un equipo con personas increíbles, que han ido llegando, llenándome y llevándome por un camino que solo sumaba.

Miguel, no has sido un jefe, has sido un mentor. Y no quiero darlo por hecho porque me siento afortunado. Gracias por confiar en mí desde el principio, por tener siempre la puerta del despacho abierta, por darme voz (tanto en el laboratorio como en todos los cursos y congresos a los que he podido ir) y por dejarme evolucionar profesionalmente. Gracias por tu generosidad, por dejarnos explorar, equivocarnos, y buscar soluciones. Puede que sea menos práctico, pero nos hace crecer como científicos y no todo el mundo está dispuesto a asumirlo. Me voy orgulloso y feliz de ser parte de tu linaje.

Teresa, la siguiente culpable eres tú. Me contagiaste tu entusiasmo e ilusión por la ciencia. Me llevaste de la mano en los inicios, y estoy muy orgulloso del equipo que formamos. Gracias por hacerlo fácil, por estar ahí, directa como tú eres, por convencerme para quedarme, por tus ánimos y tus críticas, siempre constructivas. Te admiro y me encanta la idea de que volvamos a cruzarnos.

Melisa, tu fuerza y tus ganas siempre reconfortan. Me has transmitido la constancia y perseverancia imprescindibles para estos años. Gracias por sacar siempre una sonrisa, y por todos los momentos entrañables que hemos acumulado.

Y si sumo momentos, experiencias y horas, dentro y fuera del laboratorio, Julio, eres el que apareces en más. Me alegro mucho de que hayamos hecho todo el camino juntos. Has sido uno de los protagonistas en esta historia. No podíamos ser más diferentes y, quizás por eso, has movido y me has removido tantas veces. Nos hemos regalado confianza, y creo que nos ha hecho ganar perspectivas a los dos, personal y científicamente. Gracias por estar siempre dispuesto a discutir, y a exprimir todo. Gracias por tus palabras y tu abrazo. 
Jesús, llegaste para darle un aire fresco al labo en el momento idóneo. Has demostrado que no te asustan los retos, y que el viento en contra no te empequeñece. Gracias por tu energía incansable, por tu creatividad dentro y fuera de la poyata, por enseñarme las dos orillas del Guadalquivir. Gracias por tu sinceridad, sobre todo por la que cuesta soltar. No quiero perderte de vista. Oye, y encuentra otro socio para la comisión de eventos y festejos, no la sueltes.

El grupo no ha dejado de cambiar y crecer, pero creo que hemos conseguido llevar una dinámica de apoyo que nos hace ser un EQUIPO en mayúsculas. Isa, tú llevas la bandera de los Manzanares. Tu valentía, tu disposición y tus ganas de ir a más hacen que me quite el sombrero. Sin saberlo, todos los días haces que recuerde lo importante que es no dejar de aprender, y que eres capaz de ser la más eficaz y conciliar una vida fuera con unas niñas maravillosas. Alba, has demostrado ser toda una jefa. Gracias por tu ayuda con la bioinformática, por tirar del carro sola, por no rendirte. Estoy convencido de que vas a llegar donde quieras porque, aunque todavía no confías, eres un ejemplo de no conformarse. Mariajo, gracias por llegar con todas las ganas de aprender en el equipo blastocisto, por querer implementar cosas nuevas y por saber negociar. Te dejo la capitanía. No quieres hacerte mayor, pero estás en el top de veteranos. Raquel, a ti te dejo la chapa de senior. Mucho ánimo para la recta final, que toca echar el resto. Claudio, gracias por compartir tu experiencia y por ser el primero en querer ayudar y dar estructura al laboratorio. Gonzalo, has sido intermitente, pero me ha encantado compartir los huecos que te dejaba tu horario de locura. También estoy encantado con la nueva tanda de manos y cabezas que van a seguir tirando del espíritu Manzanares. Antonio, gracias por dar el callo en momentos difíciles y por abrirte con tu locura (pero vigílala). Sigue brindándonos grandes momentos y envidias gastronómicas. Marta, tengo debilidad por ti. Con tus ganas, tu empeño y tus ideas, estoy seguro de que una vez te asientes vas a ser imparable. Me quedo con todos nuestros ratos de crear proyectos locos, y me voy convencido de que el futuro del blastocisto queda en buenas manos. ¡Quiero verte en Woods Hole! Javi, gracias por estar siempre dispuesto a echar una mano y a aprender lo que te pongan. María, en menos de un año te has convertido en un talismán. Me da mucha pena que no vayamos a compartir más tiempo. Gracias por enfangarte hasta el fondo en todo lo que te ha caído, aunque a veces sea poco 
agradecido, y no perder la energía. También quiero acordarme de todos los que han sido parte del grupo, por más o menos tiempo, en estos años. Gracias a Eva Alonso, Luis y Elena por darme la bienvenida; a Inma por enseñarme la clave de una buena organización; a Eva Fernández-Cáceres por acercarnos a la bioinformática y por todos los buenos ratos; a Aurora, por compartir tu última etapa CNIC con nosotros y por dejarnos boquiabiertos con las otras auroras. A todos los estudiantes de grado, máster y cicerones que han pasado: María Pérez, Lorena (mi primera y super eficiente cicerone, me alegro de que vayamos a volver a coincidir), Claire (je vais toujours me rappeler de ta voix et les moments qu'on a passé ensemble), Sara, Marcos (no hace falta que mencione tus momentazos, eres muy grande) y por supuesto Antonio López. Nunca pensé que mi paso por el teatro me llevaría a poder darle un toque de ingeniero a este trabajo. Gracias por sumergirte sin miedo en el proyecto (y en Cabo de Palos), por confiar en mí, por hacerlo todo fácil y por darle forma a vTONI (sí, a Jesús le debemos el nombre, como no podía ser de otra forma; y a Miguel que me diese alas para jugar a dirigir). Estoy muy orgulloso de lo que has conseguido, porque es tuyo. $Y$ estoy muy contento de que esto me haya permitido conocerte más. Eres único, y quiero seguir teniéndote cerca.

Fuera del grupo también he estado rodeado de personas que han hecho muy especial esta etapa. Héctor, gracias por ser tú, por tus ideas, tus comentarios y por estar siempre ahí. Macarena, no sé cómo pasó pero, sin darme cuenta, te convertiste en imprescindible. Gracias por dibujar sonrisas, por salvarme y porque, aunque tienes una agenda difícil, sé que estás al otro lado. Gracias a Cris del Carmen y a Briane, la combinación de calma y locura que me han dejado tantos ratos de risas. Gracias a Cambados por los inicios: Rocío (tu resiliencia es envidiable), Susana, Dani y Cris Gutiérrez. Siempre vais a estar en los pilares de esta aventura. Gracias a todas las personas que forman y formaron la familia de la tercera sur: Itziar (me ha hecho mucho ilusión que incluso hayamos trabajado juntos), Ángel, Alejandra, Geo, Jose, Carla, Diana, Elías, Cris, Sara, Sandra, Raquel del Toro, Andrés, Xavi, María Tomé, Laura, Fran...; y de la norte: Guille, Gaetano, Bea, Juli, Dimitris, Lao, Marcos, Paula, Rebeca, Piñeiro (me ha encantado compartir la última etapa), Vane, Cova, José Antonio, Ghislaine, Sandra, Noelia, Isaac, Susana, Samu, Luis, Tania, Vero, Wen, María Galardi, Andrés Sanz, Marina y un largo etcétera. Gracias a mucha gente de otras plantas que también se han cruzado en el lío. Javi, me alegro de que hayamos vuelto a 
coincidir después de la carrera porque esta vez ha sido más de verdad, y ha dado para mucho. Jose (gracias por tu humor), Ana (tienes un corazón enorme), Eli (por las ganas que le pones a todo), Paula, Laura, Carles... Me quedo con muchas tardes de Montoya.

Gracias a todas las unidades que han hecho más fácil el trabajo. Sobre todo a Laura y Dani, por toda su ayuda con el tracking de los embriones; a Vero, Elvira, Hélio y Antonio por hacer las horas de microscopía mucho más llevaderas; a Manuel José por escuchar mis dudas y ayudar con la bioinformática; a Alberto y Sergio por su disposición con la genómica; a Giovanna, Nines, Paco y Elisa por sus consejos con las células; a Elena y Mariano por hacer más fácil mi aproximación al sorter. Gracias, Sonia, por hacer la burocracia menos dolorosa y animar los saraos de la planta junto con Nieves. Gracias, Teresa, por tu energía y ahorrarnos tanto trámite de compras. Gracias, Marta, por toda la gestión de papeleos que nos abruma. Y gracias a Ana López Dorado y a Luis, a toda la gente de recepción, cafetería, almacén, informática, compras, formación, instrumentación, bioseguridad, cultivos, cocina, seguridad... Mil gracias a Frank y Merche, y todos los de allí abajo, por cuidar de nuestros ratones y estar siempre atentos para ayudar y hacernos la vida más cómoda.

I also want to acknowledge all the people in Kat's lab for making me feel I was at home during the months I was in New York. Thank you, Kat, for being always ready to talk and help, thank you for your advises. Thank you, Min, for all your help with the in vivo imaging. I want to thank Néstor, Sophie Balmer, Sophie Morgani, Nadine, Vidur, Laina and Sonja for the great memories I have from those days. Moreover, I want to mention all the people that made the 2017 Embryology Course possible in Woods Hole. It has been, undoubtedly, the most special and intense course I have been to. Thank you for making me remember the magic of science and the beauty of all the organisms we were exposed to. Thanks to the organisers, Rich and Dave, to the faculty for their advises, and especially to all the lab mates for creating such a good atmosphere. It was a one-of-a kind experience.

Quiero dar las gracias a todos los investigadores del CNIC y a todos los que me he ido encontrando en congresos por sus preguntas y comentarios que también nos ayudan a seguir adelante. 
Gracias a mis padres y mi hermana por apoyarme sin necesitar entender todo lo que hago ni lo que supone el mundo científico. Os quiero, y sé que siempre estáis ahí. Gracias a Sandra, Lorena, Alba, Esmeralda, Yoli, Carlos, Gema y Javi, por ser la familia ampliada que acompaña los grandes eventos y los pequeños detalles.

Gracias a mis amigos de la universidad \& co. por entender mis ausencias y seguir caminando juntos: Rober (el link con el CNIC), Azahar, Juanga, Carla, Jorge, Laura, Javi, Adri, Sergio, Ana, Tati, Irene y Dani. Gracias a María, Ángela, Moni, Rubén y Adri por los ratos de ponernos al día. Gracias a Alfonso y Laura por los reencuentros.

Gracias a toda la gente que envuelve la burbuja de teleco y NECN porque me habéis dado mucho más de lo que pensaba cuando me acerqué al mundo del teatro y los musicales. Los ratos de desconectar de la ciencia han sido, en gran parte, para involucrarme en esto. Por los miércoles de cañas: Pecha, Costa, Amorfo, Ana, Mera, Chechi, Joyu y Miriam. Por las tardes y findes de ensayo: Fagot (gracias por confiar), Izarne (gracias por darle tu toque profesional al envoltorio de la tesis y por dejarme acompañarte en mi viaje más exótico hasta la fecha), Antonio, Querencias, Jack, Susana, Elena, Irati, Alfonso, Graus, Manu, Mario, Ali, Celia, Sonia, Papi, Alba, Gago, Bea y muchos más.

Gracias a todos los que me habéis acompañado durante estos años de un modo u otro. Han sido muchas horas, mucho esfuerzo, muchas risas, algún rato duro, pero todo ha sido único gracias a las personas que estabais detrás. 
SUMMARY 
A central question in developmental biology is how a single cell, the zygote, divides and differentiates to generate all the specialised cells that will build a whole organism. The zygote has totipotent capacity, which means that it is able to give rise to any necessary cell type (embryonic or extraembryonic) to form an adult individual. This capacity is gradually reduced during embryonic development, as cells make fate decisions that increase their specialisation at the expense of restricting their developmental potential.

The first lineage choice of the mammalian embryo occurs before its implantation in the maternal uterus (so-called preimplantation development) at the blastocyst stage, and leads to the appearance of the first morphologically distinct cell populations: the trophectoderm and the inner cell mass. The trophectoderm is characteristic of mammals and will give rise to extraembryonic tissues such as the placenta, while the inner cell mass will form the embryo proper.

$C d \times 2$ is the key gene required for the specification of the trophectoderm and is regulated by the cooperation of two signalling pathways: Hippo and Notch. The Hippo pathway functions as a readout of intracellular polarity cues starting at the morula stage, but little is known about the role of Notch in preimplantation before the blastocyst stage. By using genetic and pharmacological tools in vivo, together with image analysis of single embryos, we have found an early requirement for Notch, which is active from the 4-cell stage, and precedes that of Hippo in the regulation of $\mathrm{Cd} \times 2$. Moreover, transcriptomic analysis identified novel Notch targets at these stages including early naïve pluripotency markers or transcriptional repressors such as Tle4. Our results unveil a role for Notch in driving the transition towards a more committed state during the gradual loss of potency that takes place in the early mouse embryo prior to the first lineage decisions. 
Una pregunta central en el campo de la biología del desarrollo es cómo una única célula, el zigoto, se divide y se diferencia para generar todas las células especializadas que forman un organismo. El zigoto tiene una capacidad totipotente, es decir, es capaz de dar lugar a cualquier tipo celular (embrionario o extraembrionario) necesario para la formación de un individuo adulto. Esta capacidad se reduce gradualmente durante el desarrollo embrionario dado que las células toman decisiones de linaje que suponen un aumento de su especialización a expensas de un potencial más restringido.

La primera decisión de linaje del embrión de mamíferos ocurre antes de su implantación en el útero materno (a lo que se llama desarrollo preimplantacional) en el estadio de blastocisto, y supone la aparición de las primeras poblaciones celulares morfológicamente distintas: el trofoectodermo y la masa celular interna. El trofoectodermo es característico de los mamíferos y dará lugar a estructuras extraembrionarias como la placenta, mientras que la masa celular interna formará el embrión.

$C d \times 2$ es un gen clave necesario para la especificación del trofoectodermo, y se regula gracias a la cooperación de dos vías de señalización: Hippo y Notch. La vía de Hippo traduce las señales que recibe de polaridad intracelular desde el estadio de mórula, pero el papel de la vía de Notch en estadios preimplantacionales es poco conocido. Mediante el empleo de herramientas genéticas y farmacológicas in vivo, junto con análisis de imagen de embriones individuales, hemos descubierto un requerimiento temprano de la vía de Notch, que está activa desde el estadio de 4 células, precediendo así al de la vía de Hippo en la regulación de $C d \times 2$. Además, análisis transcriptómicos nos han llevado a identificar nuevas dianas de Notch en estos estadios, entre los que se incluyen marcadores de pluripotencia naíf o represores transcripcionales como Tle4. Nuestros resultados revelan, por tanto, que Notch tiene un papel dirigiendo la transición hacia estados más comprometidos celularmente durante la pérdida gradual de potencial que tiene lugar en el embrión temprano de ratón, antes de la primera decisión de linaje. 
SUMMARY

RESUMEN

INDEX

LIST OF FIGURES

LIST OF ACRONYMS

INTRODUCTION

The mammalian embryo: a self-organising system

Emergence of cellular heterogeneity in the mouse preimplantation embryo 36

The first choice: embryonic versus extraembryonic .39

Establishment of trophectoderm fate

Plasticity during fate specification

Capturing the first lineages in culture

Spatio-temporal control in development: gene regulatory elements .49

OBJECTIVES

MATERIALS AND METHODS

Animal experimentation .59

Embryo collection and culture .60

Immunofluorescence of preimplantation embryos .60

Imaging and quantification .61

Fluorescent in situ hybridisation 
RT Quantitative-PCR

RNA-sequencing data analysis

Transient transgenic assay

Mutagenesis

CRISPR/Cas9 genome editing

Cell Culture

Statistics

RESULTS

1. Convergence of Notch and Hippo pathways on $C d x 2$ regulation .69

1.1 Effect of genetic disruption of Rbpjand Tead4 in the morula

1.2 Imaging of CDX2, YAP and NOTCH activity during preimplantation development ...71

2. Do Notch and Hippo have a redundant role on $C d x 2$ expression? . .74

3. Temporal modulation of Notch and YAP inhibition . .75

4. Notch regulates the early phase of $C d x 2$ expression . .77

5. Maternal contribution of $R b p j$ is not necessary for $C d \times 2$ expression .79

6. The Notch pathway is heterogeneously active in the embryo starting at the 4-cell stage

7. Notch activity dynamics in the morula to blastocyst transition

8. Different Notch levels determine cell position in the morula and in the blastocyst

9. Lack of Rbpjdisrupts the triggering of differentiation programs in the morula . .90

10. Notch regulates the transcriptional repressor coding genes Tle4 and Tbx3 in the early embryo

10.1 Notch-mediated regulation of Tle4 in the preimplantation embryo.

10.2 Deciphering the regulation of $T b \times 3$ in the preimplantation embryo

11. Notch coordinates the balance between naïve pluripotency and triggering of differentiation in ES cells .98 
11.1 Naïve pluripotency genes in the preimplantation embryo

11.2 Different Notch levels coordinate the transition from a naïve state to commitment for differentiation in ES cells 100

12. Expression of Notch pathway components in the preimplantation embryo 103

DISCUSSION 107

Different signalling pathways work together to establish cell fate 109

Early activation of Notch signalling 111

Triggering of cell differentiation

Novel targets of Notch: Tle4 and Tbx3

Notch drives transitions in cell potency during mouse preimplantation

development

CONCLUSIONS

CONCLUSIONES

BIBLIOGRAPHY 


\section{LIST OF FIGURES}

Figure 1. Images and schematic representations of unicellular embryos from five different species.

Figure 2. Mouse preimplantation development.

Figure 3. The circuitry defining pluripotency and trophectoderm networks.

Figure 4. Driving the first lineage choice.

Figure 5. Hippo and Notch regulate CDX2.

Figure 6. Regulation model of $C d x 2$.

Figure 7. Distribution of embryos by genotype.

Figure 8. CDX2 depends on Rbpjand Tead4 inputs.

Figure 9. Lack of Rbpj and Tead4 does not affect compaction or polarisation.

Figure 10. The Notch pathway is active in the preimplantation embryo.

Figure 11. CDX2 expression relies on the input from Notch and Hippo signalling pathways.

Figure 12. Overexpression of N1ICD does not fully rescue Tead4 null phenotype.

Figure 13. Notch and Hippo sequentially pattern $C d x 2$.

Figure 14. CDX2 decreases in Rbpj mutant early morulae.

Figure 15. CDX2 decreases in Notch1 mutant early morulae.

Figure 16. Removal of maternal and zygotic Rbpj does not exacerbate CDX2 decrease.

Figure 17. The Notch pathway is active from the 4-cell embryo.

Figure 18. Live imaging of morula to blastocyst transition in CBF1-VENUS embryos.

Figure 19. 3D visualization of embryos after time lapse imaging.

Figure 20. CBF1-VENUS dynamics in the morula to blastocyst transition.

Figure 21. Confronting different Notch activity levels within the embryo.

Figure 22. Differences in Notch activity drive cell fate in the preimplantation embryo.

Figure 23. Transcriptome profiling of Rbpj mutant morulae.

Figure 24. Differentially expressed genes between control and Rbpjmutant morulae. 
Figure 25. Analysis of differentially expressed genes in Rbpj mutants versus control morulae.

Figure 26. Notch signalling inhibition leads to reduction in $T b \times 3$ and Tle4 expression.

Figure 27. An RBPJ consensus binding site is necessary for full activity of the Tle4-up enhancer.

Figure 28. Tle4 is a direct target of RBPJ.

Figure 29. Testing the regulation of $T b \times 3$ in the morula.

Figure 30. Naïve pluripotency markers in the preimplantation embryo.

Figure 31. Notch inhibition increases Prdm14 expression.

Figure 32. Notch levels correlate negatively with naïve pluripotency.

Figure 33. Notch promotes cell differentiation of ES cells.

Figure 34. Expression of Notch pathway components in the preimplantation embryo.

Figure 35. Jag2 and D/I1 expression in the blastocyst.

Figure 36. Divergent patterns of expression between Prdm14 and Notch activity.

Figure 37. Proposed network regulated by Notch signalling during mouse preimplantation development.

Figure 38. Temporal activity of the Notch pathway during preimplantation development. 


\section{LIST OF ACRONYMS}

\begin{tabular}{|c|c|}
\hline $4 \mathrm{OH}-\mathrm{Tx}$ & 4-Hydroxy-Tamoxifen \\
\hline ATAC-seq & Assay for Transposase Accesible Chromatin and sequencing \\
\hline BAC & Bacterial Artificial Chromosome \\
\hline bp & base pairs \\
\hline DAPI & 4',6-diamidino-2-fenilindol, 4',6-diamidinofenyl-indol \\
\hline DEG & Differentially Expressed Genes \\
\hline DMSO & Dimethyl Sulfoxide \\
\hline DN & Dominant Negative \\
\hline dpf & days post fertilisation \\
\hline $\mathrm{E}$ & Embryonic day \\
\hline Epi & Epiblast \\
\hline ES cell & Embryonic Stem cell \\
\hline GOF & Gain Of Function \\
\hline gRNA & guide-RNA \\
\hline HET & Heterozygote \\
\hline ICM & Inner Cell Mass \\
\hline iPSC & Induced Pluripotent Stem Cell \\
\hline IRES & Internal Ribosomal Entry site \\
\hline $\mathrm{Kb}$ & Kilobases \\
\hline KO & Knockout \\
\hline LOF & Loss Of Function \\
\hline $\mathrm{mut}^{\mathrm{RBPJ}}$ & mutated RBPJ motif \\
\hline MZ & maternal-zygotic \\
\hline NICD & Notch Intracellular Domain \\
\hline PrE & Primitive Endoderm \\
\hline RNA-seq & RNA sequencing \\
\hline RO & RO4929097, gamma secretase inhibitor \\
\hline RT & Room Temperature \\
\hline RT-qPCR & Real Time Quantitative PCR \\
\hline s.d & standard deviation \\
\hline s.e.m & standard error of the mean \\
\hline Tbx3-i7 & Intron 7 of the Tbx3 locus \\
\hline TE & Trophectoderm \\
\hline TEE & Trophectoderm Enhancer \\
\hline TF & Transcription Factor \\
\hline Tle4-up & Region upstream of the Tle4 locus \\
\hline TS cell & Trophoblast Stem cell \\
\hline WT & Wildtype \\
\hline
\end{tabular}


INTRODUCTION 
Developmental biology studies how an organism is built starting from a fertilised egg. It is a field of dynamic rather than static pictures, and focuses in fate acquisitions, transitions between cellular states or morphogenetic organizations. Understanding differentiation, shape and growth are the pillars of this discipline. Since the initial studies of embryology (the mother discipline of developmental biology) more than a century ago, important breakthroughs have answered fascinating questions to better understand life through anatomical, experimental and genetic approaches. In the 1800s, Karl Ernst von Baer claimed that development proceeds from homogeneous to heterogeneous and specialized features, finishing off the preformationist ideas (Buettner, 2007). Since then, the view of developmental biology has shifted to include theoretical and methodological contributions from evolution, phylogeny, cell biology, genetics or stem cell biology (Gilbert, 2017).

In the mid-1900s, Conrad Hal Waddington introduced for the first time the idea of development as a series of branching decisions, taken under the control of genes (Slack, 2002). His ideas on decision-making are still at the roots of how we understand development today.

\section{The mammalian embryo: a self-organising system}

Multicellular organisms develop from a single cell, the zygote, no matter if this is a worm, an insect, an amphibian or a human being. The unicellular zygotes from evolutionary distant species may look alike despite generating completely different animals. However, there is a particular feature that we find mostly in mammals: regulative development. In many species like sea urchins ( $P$. lividus), worms (C. elegans) or flies (D. melanogaster), the zygotes present asymmetric distribution of proteins or mRNAs, maternally segregated in the oocyte, that will dictate the fate of descendant cells that inherit those factors (Figure 1) (Davidson, 1989, 1990; Sulston et al., 1983; Wieschaus, 2016). This is known as pre-patterned or mosaic development. In contrast, mammalian zygotes do not show any clear asymmetry and even during three rounds of division in mice, cells are equal in terms of geometry and developmental potential (Figure 1, Figure 2). Cell fate 
is acquired through a self-organising model by the combined influence of factors intrinsic to each cell, such as gene expression, and factors resulting of cell-cell interactions, such as mechanical inputs (Wennekamp et al., 2013). The terms of mosaic and regulative development have been used for decades to classify the way the organisms develop. Nevertheless, it has been shown that these processes are not mutually exclusive and we cannot talk about totally pre-patterned or regulative development. All embryos depend on cell-cell interactions to some extent, reinforcing or not the signals provided by localized determinants (Condic, 2016; Lawrence and Levine, 2006). What is unquestionable is the inherent plasticity that the first cells to be generated in mammalian embryos possess.

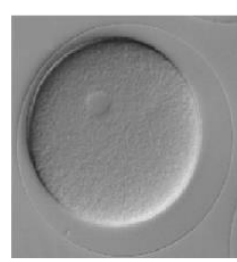

P. lividus

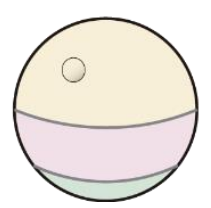

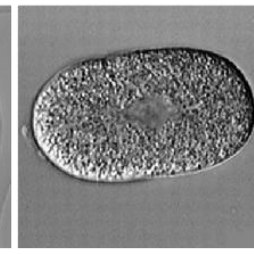

C. elegans

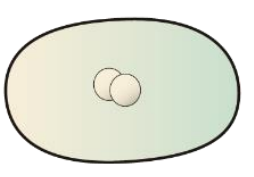

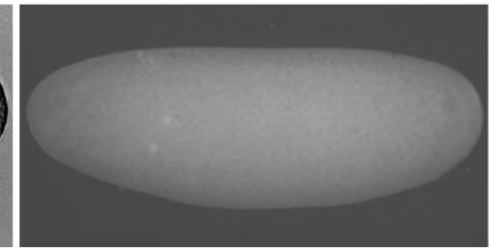

D. melanogaster

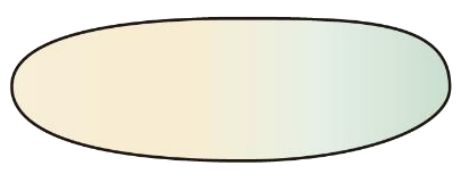

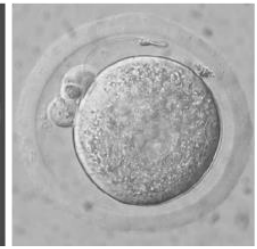

M. musculus

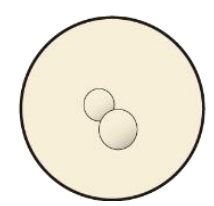

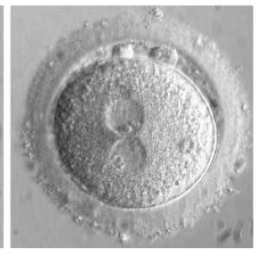

H. sapiens

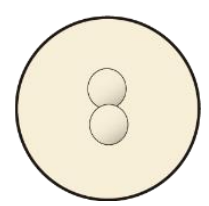

Figure 1. Images and schematic representations of unicellular embryos from five different species. From left to right: sea urchin (Paracentrotus lividus), nematode (Caenorhabditis elegans), fly (Drosophila melanogaster), mouse (Mus musculus) and human (Homo sapiens). Gradient of colours represent asymmetric distribution of maternal determinants. Images from the author and from (Baruni et al., 2008; Gildor et al., 2017; Nien et al., 2011).

\section{Emergence of cellular heterogeneity in the mouse preimplantation embryo}

The newly fertilised mouse zygote undergoes a series of synchronous divisions that results in an increase in the number of cells while the global size of the embryo is roughly maintained. These cells, called blastomeres, are initially indistinguishable until the 8-cell 
embryo and retain full potential to become any cell of the embryo (Figure 2). Even isolated blastomeres from 2-cell and 4-cell embryos have the capacity of developing into a whole embryo (Suwińska et al., 2008; Tarkowski, 1959; Tarkowski et al., 1967). This totipotent capacity will be gradually lost leading to the generation of specialised cells that will progressively take lineage decisions resulting in commitment to specific fates.

Despite their morphologically similar aspect, recent studies on single-cell gene expression have reported differences among blastomeres of the 4-cell embryo. Moreover, these differences can bias the contribution of descendant cells to one lineage or another (Burton et al., 2013; Goolam et al., 2016; Torres-Padilla et al., 2007). Blastomeres at this stage still maintain the capacity to generate any tissue in the embryo, but they acquire preferences for particular populations (Kelly, 1977; Tabansky et al., 2013; Tarkowski and Wroblewska, 1967). Thus, molecular heterogeneities appear before the potency of blastomeres is restricted.

The first morphological sign of differentiation is evident at the morula stage, two and a half days post-fertilisation ( $2.5 \mathrm{dpf}$ or embryonic day E2.5). Blastomeres in the 8-cell embryo increase their intercellular interactions and acquire an apical-basal polarity, with the apical domain facing the outer surface of the embryo (Ziomek and Johnson, 1980). This process is known as compaction and is driven by periodic cortical waves controlled by the actomyosin cortex together with E-cadherin (CDH1) (Maitre et al., 2015). In the following rounds of cell division, blastomeres can divide symmetrically or asymmetrically. As a result, two populations emerge in the embryo: an outer population of polarised cells that enclose an inner population of apolar cells (Johnson and Ziomek, 1981; Tarkowski and Wroblewska, 1967; Ziomek and Johnson, 1980). The inner or outer position of a blastomere are still considered the basis of the first fate decision. However, recent reports have shown that the initial position of blastomeres in the embryo or the division angle that will determine symmetric or asymmetric divisions do not consistently predict their fate. Relocations of cells within the embryo have been regularly found (Anani et al., 2014; McDole et al., 2011; Toyooka et al., 2016; Watanabe et al., 2014). Heterogeneous tensile forces in outer cells make myosin II to accumulate around constricting cells that will become embedded in the inner population (Samarage et al., 2015). Also, polarised and 
apolar blastomeres show heterogeneities in contractility. Outer apolar cells have more cortical myosin and a higher contraction amplitude than polar cells, and this triggers its internalization (Maitre et al., 2016).

At the $\sim 32$-cell stage, a fluid-filled cavity known as the blastocoel begins to form within the embryo. The blastocoel is maintained by a seal formed by tight junctions established between outer cells. This process is known as cavitation and entails a physical constraint in the embryo. As the blastocoel expands, outer cells epithelialize and inner cells are relocated to one end of the cavity. The embryo then reaches the blastocyst stage (Figure 2). At this point (E 3.5), the two first cell populations to appear during mouse development are clearly distinguished. The outer epithelial layer forms the trophectoderm (TE) while the inside apolar population forms the inner cell mass (ICM). A day later (E 4.5), the cells forming the ICM are sorted into two new populations: a monolayer lying in contact with the blastocoel, known as primitive endoderm ( $\operatorname{PrE})$ or hypoblast; and the epiblast, which remains enclosed between the TE and the PrE, and gives rise to the embryo proper. At this moment, the embryo is ready to implant in the maternal uterus.

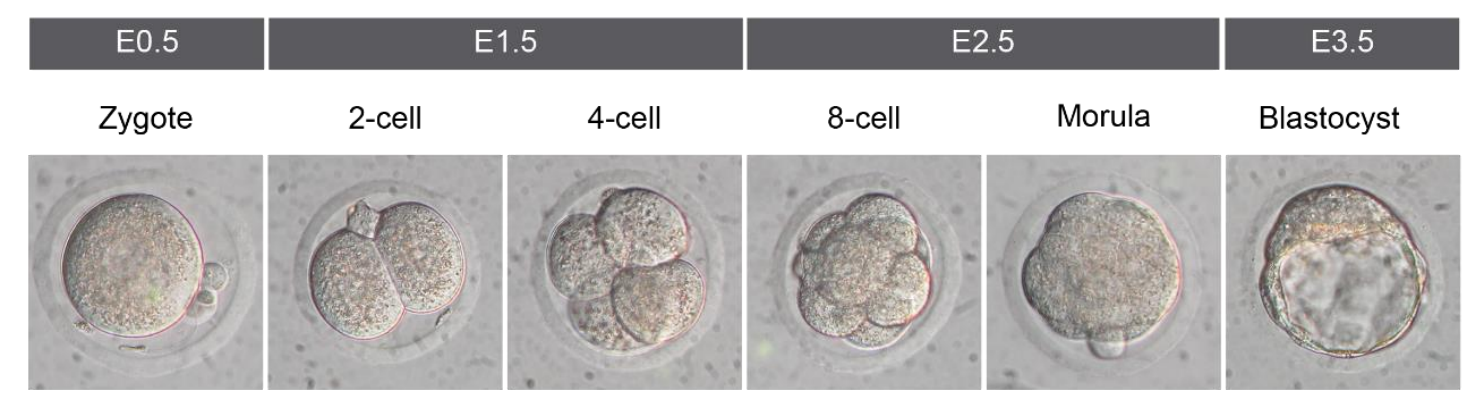

Figure 2. Mouse preimplantation development. Overview of wide field microscopic images of embryonic stages from the totipotent zygote up to the blastocyst stage, in which the trophectoderm and the inner cell mass have been segregated. Upon fertilisation, the unicellular zygote undergoes a series of divisions that do not alter the total size of the embryo. 


\section{The first choice: embryonic versus extraembryonic}

The two first cell populations determined between the second and the third day after fertilisation, during the transition from morula to early blastocyst, are the result of the first lineage decision of the embryo. Blastomeres are segregated between an embryonic fate, being part of the pluripotent ICM, and an extraembryonic fate, forming the differentiated TE. The TE gives rise to the extraembryonic ectoderm and the ectoplacental cone in the early postimplantation embryo, which will later differentiate into the major portion of the fetal placenta. In contrast, the ICM forms the embryo proper, the yolk sac and the allantois.

The emergence of these populations is underpinned by a transcriptional circuitry that orchestrates the fate of every cell. The core of these networks is a set of transcription factors (TFs) that trigger specific programs and drive the establishment of one lineage or another. Two different programs control the first lineage choice: the pluripotency network and the TE network.

The key genes of the pluripotency network are Oct4 (Pou5f1) (Nichols et al., 1998), Nanog (Chambers et al., 2003; Mitsui et al., 2003) and Sox2 (Avilion et al., 2003). This set of TFs maintain pluripotency both in vivo and in vitro, and at the same time repress differentiation. $C d \times 2$ is the main component in the regulatory network determining the TE lineage (Strumpf et al., 2005), a mammalian homologue of the Drosophila homeotic gene caudal (Mlodzik et al., 1985) that encodes a homeodomain TF. Other markers related to the TE are the TFs Gata3 and Gata2 (Home et al., 2009, 2017; Ralston et al., 2010), Eomes (Russ et al., 2000), Tfap2c (Cao et al., 2015) or the cytokeratin intermediate filament Krt8. Intriguingly, KIf5 regulates markers of both the embryonic and the extraembryonic lineages (Lin et al., 2010). Cdx2 null embryos are unable to maintain the blastocoel, and the expression of other TE markers is impaired while pluripotency factors such as OCT4 and NANOG are detected in all cells (Huang et al., 2017; Strumpf et al., 2005). Accordingly, the core pluripotency network represses the expression of TE specific genes (Niwa et al., 2005), and the absence of Oct4 leads to increased predisposition to differentiate towards trophoblast both in vivo and in vitro (Nichols et al., 1998; Niwa et 
al., 2000). Thus, the first lineages are established and maintained through the progressive activation of TFs from one network and the repression of the opposite one (Figure 3).

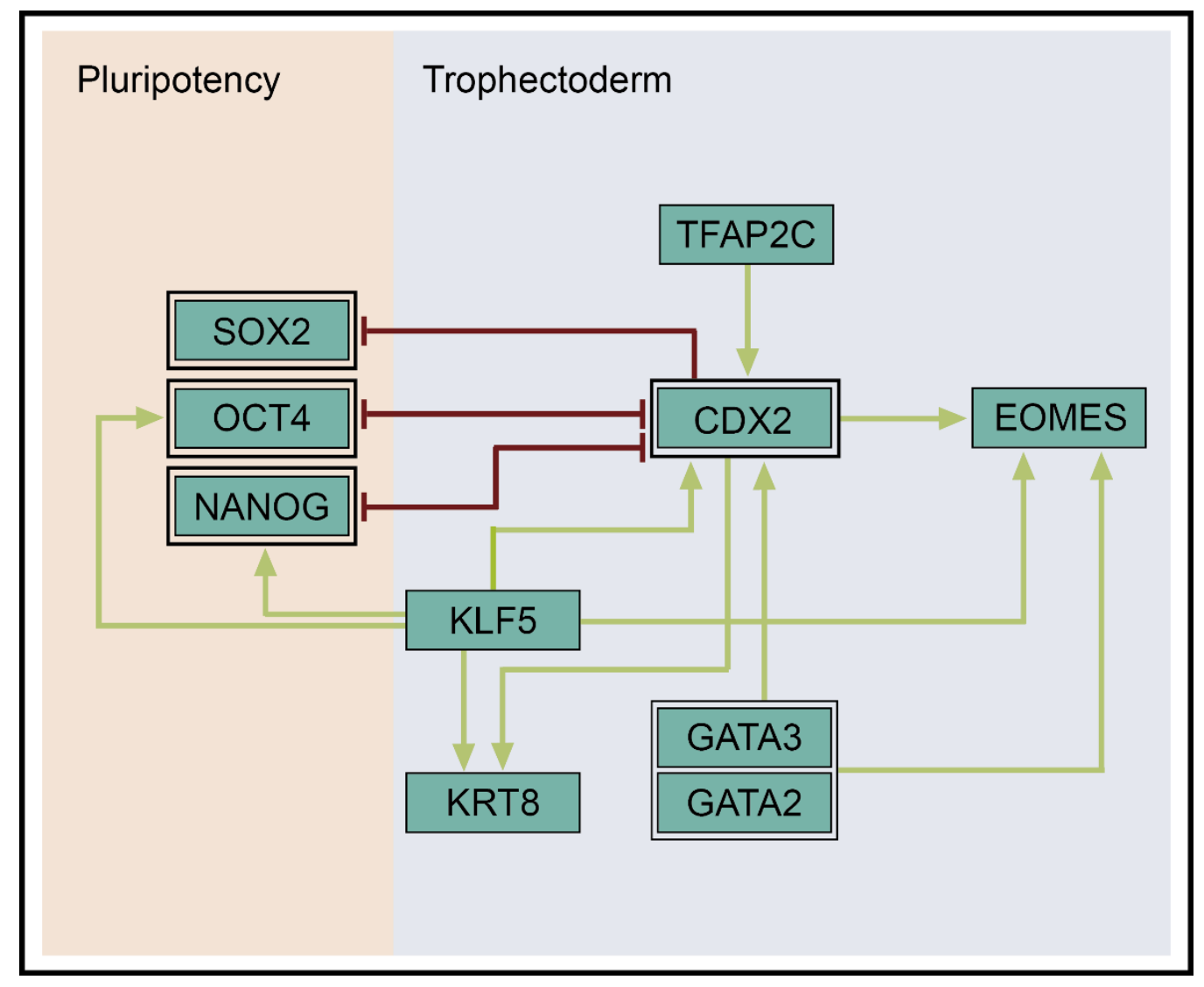

Figure 3. The circuitry defining pluripotency and trophectoderm networks. Interactions described between core members of the pluripotency (left panel) and trophectoderm (right panel) networks. Green arrows indicate activation and red lines indicate repression. Modified from (Menchero et al., 2018).

The expression pattern of OCT4, NANOG, SOX2, CDX2 or GATA3 is initially ubiquitous and stochastic, and it is only at the blastocyst stage that they become restricted to their definitive domains and the two lineages are properly established (Dietrich and Hiiragi, 2007; Guo et al., 2010; Ohnishi et al., 2014; Posfai et al., 2017; Xenopoulos et al., 2015). Thus, the establishment of the first lineages is promoted by the progressive activation of TFs that shape a network and the later repression of the opposite network. The heterogeneous expression of most of these TFs reveal that no single factor per se is 
predictive of lineage segregation before the blastocyst stage, and they might not be the initial drivers of lineage decisions, but rather the managers for maintaining and executing lineage-specific programs.

\section{Box 1. Human preimplantation development.}

The understanding of human development has been historically extrapolated by comparison with other model organisms, but recent advances in transcriptomic analysis at the single cell level have allowed the ability to analyse gene expression directly in the human embryo (Wamaitha and Niakan, 2018). Preimplantation mouse and human embryos are very similar in morphology at these early stages, and most of the key lineage specifiers such as CDX2 or OCT4 are conserved (Petropoulos et al., 2016). As a general rule, the main events occurring during preimplantation stages are prolonged in the timeline of the human embryo. For instance, the embryo genome activation takes place between the 4 - and 8 - cell stage $(\sim 2.5 \mathrm{dpf})$ as compared to the 2-cell stage in the mouse ( 1.5 dpf) (Blakeley et al., 2015), cell compaction occurs between the 8- and 16-cell stage (3-4 dpf) (Nikas et al., 1996), and blastocyst formation at 64-128 cell stage (5-6 dpf) (Steptoe et al., 1971). Beyond that, differences in timing of expression and therefore timing of specification of early lineages have been described. In humans, the three lineages (trophectoderm, epiblast and primitive endoderm) are specified more simultaneously and at later stages as compared to the mouse (Petropoulos et al., 2016). Single-cell RNA-seq analysis in human samples have provided a valuable resource of the temporal changes in term of expression that are taking place (Stirparo et al., 2018). Future approaches may give insight on the genomic cues that control the heterochrony in mouse and human preimplantation embryos. 


\section{Establishment of trophectoderm fate}

$C d x 2$ is first expressed in the 8-cell embryo upon compaction in a salt-and-pepper pattern before becoming restricted to the TE in the early blastocyst (Dietrich and Hiiragi, 2007; Posfai et al., 2017; Ralston and Rossant, 2008). Cdx2 is in fact the first core factor that delimit its spatial expression to its definitive domain. Two signalling pathways have been described to lie upstream of $C d x 2$. the Hippo pathway and the Notch pathway.

Hippo is the main pathway described to have a role in the first lineage choice. It was first identified in Drosophila and it is involved in tissue growth control (Meng et al., 2016; Pan, 2010). Mammals have an analogous pathway that includes the main components described in the fly. However, in the preimplantation embryo, Hippo has not been associated to growth regulation but instead provides the link between cell polarisation and fate. The differential distribution of Hippo pathway components in polarised and unpolarised blastomeres dictates the activity of the pathway (Manzanares and Rodriguez, 2013; Sasaki, 2015). In apolar inner cells, where the Hippo pathway is active, the junctionassociated protein AMOT (Angiomotin) localizes at adherent junctions (Hirate et al., 2013; Leung and Zernicka-Goetz, 2013). There, AMOT interacts with two other Hippo components, the LATS1/2 kinase and NF2 (Neurofibromin 2). LATS1/2 phosphorylates AMOT and stabilizes this complex together with NF2 (Hirate et al., 2013). LATS1/2 then phosphorylates the transcriptional coactivator YAP (as well as the Yap-related protein TAZ), which is retained in the cytoplasm (Nishioka et al., 2009) (Figure 4). In polar outer cells, AMOT is sequestered by the apical complex, NF2 remains in the lateral membrane, the kinases are inactive and, therefore, YAP is not phosphorylated. YAP is then translocated into the nucleus, where it acts as a transcriptional coactivator by binding the TF TEAD4, and activates the expression of its target genes that include the TE markers Cdx2 (Nishioka et al., 2009) and Gata3 (Ralston et al., 2010) (Figure 4). Disruption of Lats1/2, Amot or Nf2 impairs the correct activation of the pathway and causes ectopic nuclear YAP accumulation and CDX2 expression in inner cells (Cockburn et al., 2013; Hirate et al., 2013; Leung and Zernicka-Goetz, 2013; Nishioka et al., 2009). Lack of the effector Tead4 leads to the opposite effect: Tead4 null embryos cannot switch off the pathway in outer cells and, consequently, CDX2 is absent in most of the cells from the 
blastocysts. Moreover, these embryos are not able to cavitate nor to implant in the uterus (Nishioka et al., 2008; Yagi et al., 2007). Interestingly, this phenotype can be circumvented when Tead $4^{-/}$embryos are cultured in low oxygen conditions that reduce oxidative stress (Kaneko and DePamphilis, 2013). A recent study has shown that mitochondrial activity depends on TEAD4 in the blastocyst, defining a role not only in cell fate but also in the metabolic switch for energy production that the trophectoderm needs to mature (Kumar et al., 2018). Furthermore, the Hippo pathway also contributes to the establishment of the ICM by restricting Sox2 expression to inner cells (Wicklow et al., 2014) (Figure 4).

More recently, the Notch pathway has also been shown to regulate of $C d x 2$ during mouse preimplantation development (Rayon et al., 2014). The Notch signalling pathway is a highly conserved cell-to-cell signalling system involved in multiple cell fate decisions during embryonic development (Koch et al., 2013). Interaction of a receptor with a ligand of the pathway leads to a cascade of proteolytic events that result in the release of the Notch intracellular domain (NICD). The NICD translocates into the nucleus, where it binds the transcription factor RBPJ and the coactivator MAML and leads to activation of target genes. In the absence of the NICD, RBPJ may associate to corepressors to inhibit gene expression (Wang et al., 2015). In mammals, there are four Notch transmembrane receptors (Notch1-4) and five ligands from two different families, Delta-like (DI/I, DI/3 and D//4) and Jagged (Jag1 and Jag2). Disruption of the main components of the pathway does not affect embryo survival until postimplantation stages, and therefore a role for Notch during preimplantation development had been ruled out (Conlon et al., 1995; Shi et al., 2005; Souilhol et al., 2006). However, through the characterization of a regulatory element upstream of $C d \times 2$, the TEE, we showed that Notch signalling pathway is active in the TE and converges with the input of Hippo to regulate $C d \times 2$ expression in the mouse blastocyst (Figure 4) (Rayon et al., 2014). Double mutants for Tead4 and Rbpji the transcription factors that act as effectors of the Hippo and Notch pathways respectively, exacerbate their single phenotypes and lead to embryonic lethality before the blastocyst stage. The interaction between Notch and Hippo on the TEE is mediated by the chromatin remodeler SBNO1 (Strawberry Notch1) (Watanabe et al., 2017). SBNO1 physically interacts with the YAP/TEAD and NICD/RBPJ complexes, and lack of Sbnol prevents $C d x 2$ to be correctly induced. 


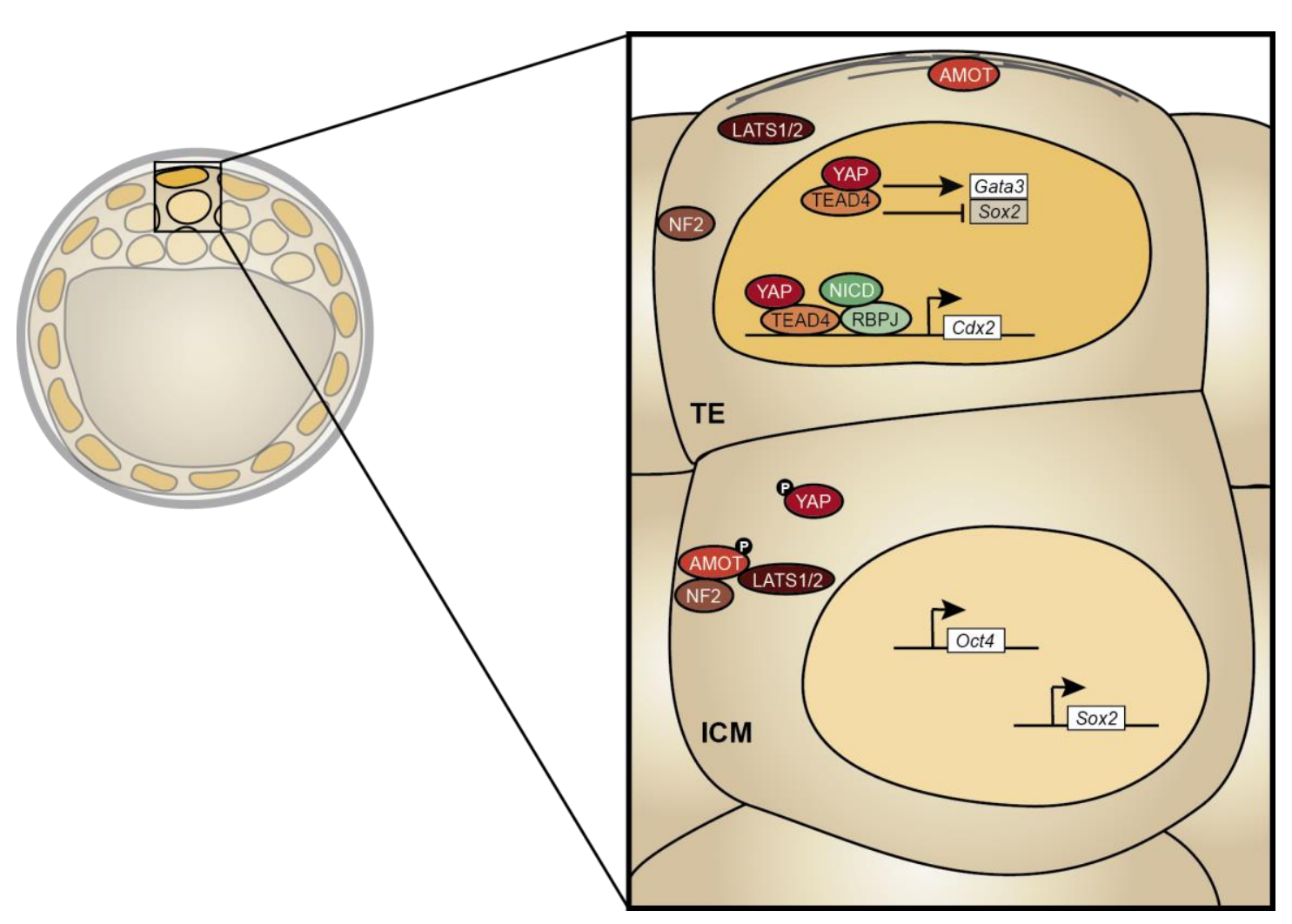

Figure 4. Driving the first lineage choice. Representation of cells showing the differential distribution of lineage markers and components of the Hippo and Notch signalling pathways in trophectoderm (TE) and inner cell mass (ICM) of a mouse blastocyst. Modified from (Menchero et al., 2017).

The activity of both signalling pathways is, therefore, delimited to the TE of the blastocyst, being the coactivators YAP and NICD translocated into the nuclei of this outer lineage (Figure 5). Before that stage, and similarly to CDX2 pattern, the activity of both pathways is heterogeneously distributed in the blastomeres of the morula (Figure 5).

Thus, the first differentiation event is driven by more than one signalling pathway. Besides Hippo and Notch, Rho/Rock signalling has been shown to mediate cell polarisation and Hippo regulation (Kono et al., 2014; Mihajlovic and Bruce, 2016). The Hippo pathway is the main one orchestrating TE fate, given that its absence drastically alters TE specification, but its role is supported by other players. These different inputs may act redundantly to ensure the robustness of embryonic development, or they may act in a 
complementary, sequential or synergistic manner to achieve correct functioning (Menchero et al., 2017).

$\begin{array}{lll}\text { HIPPO } & \text { NOTCH } & \text { CDX2 } \\ \text { NICD } & & \text { PAP }\end{array}$
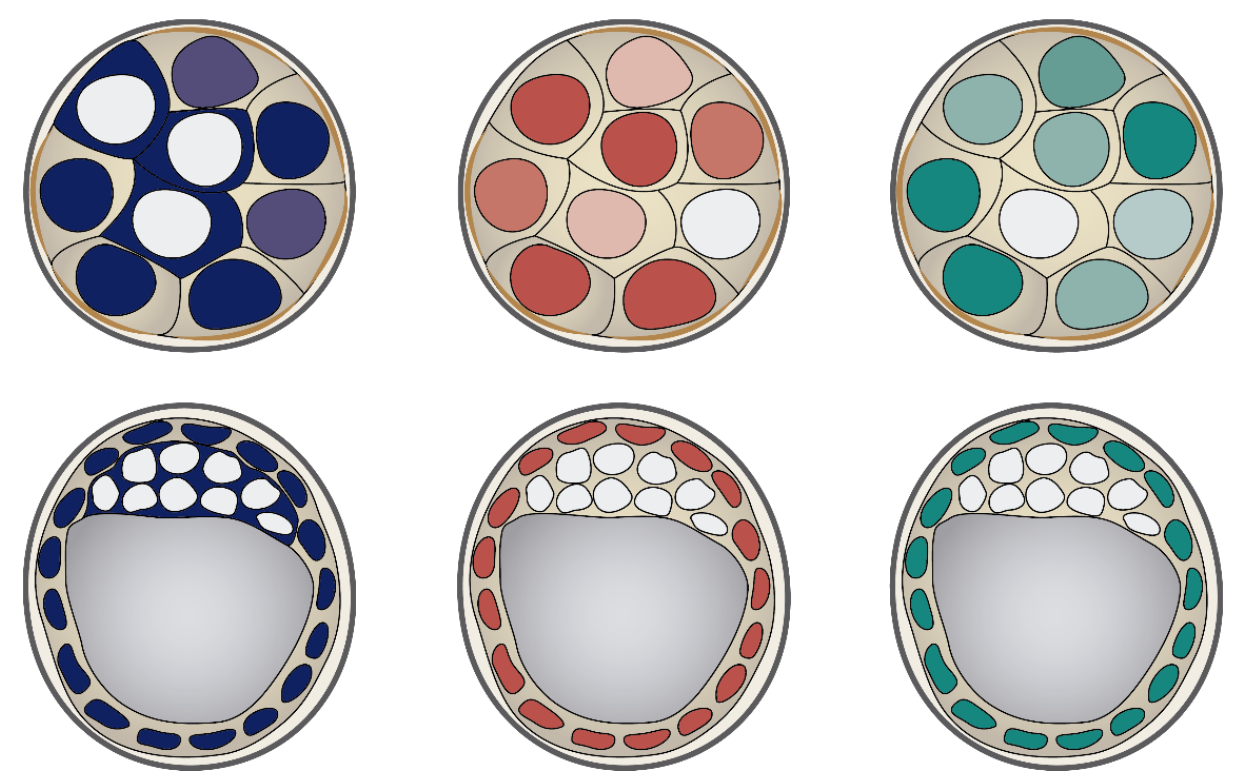

Figure 5. Hippo and Notch regulate CDX2. Heterogeneous expression of CDX2 (green), and the coactivators YAP (blue) and Notch intracellular domain (NICD, red) in the early morula. Polarised blastomeres (apical domain in ochre) correlate with nuclear YAP. Cytoplasmic YAP is highlighted in unpolarised blastomeres. In the blastocyst, YAP, NICD and CDX2 are coexpressed in the trophectoderm. Adapted from (Menchero et al., 2018). 


\section{Box 2. The Notch signalling pathway}

Notch receptors (NOTCH1-4) and ligands (JAG1-2 and DLL1,3,4) are transmembrane proteins with an extracellular domain formed by a variable number of EGF-like repeats required for the receptor-ligand interaction. Members of the Fringe family glycosylate the receptor and give Notch the selectivity for its ligand (Panin et al., 1997) and, the E3 ubiquitin-protein ligase Mind-bomb (MIB) modifies the ligand upon its binding to the receptor (Itoh et al., 2003). This event leads to a cascade of proteolytic cleavages mediated by metalloproteinases and gamma-secretases that result in the release of the Notch intracellular domain (NICD). NICD is translocated into the nucleus and bound to the transcription factor RBPJ. They recruit the coactivator Mastermind-like protein (MAML) to activate target gene expression (MacGrogan et al., 2018).

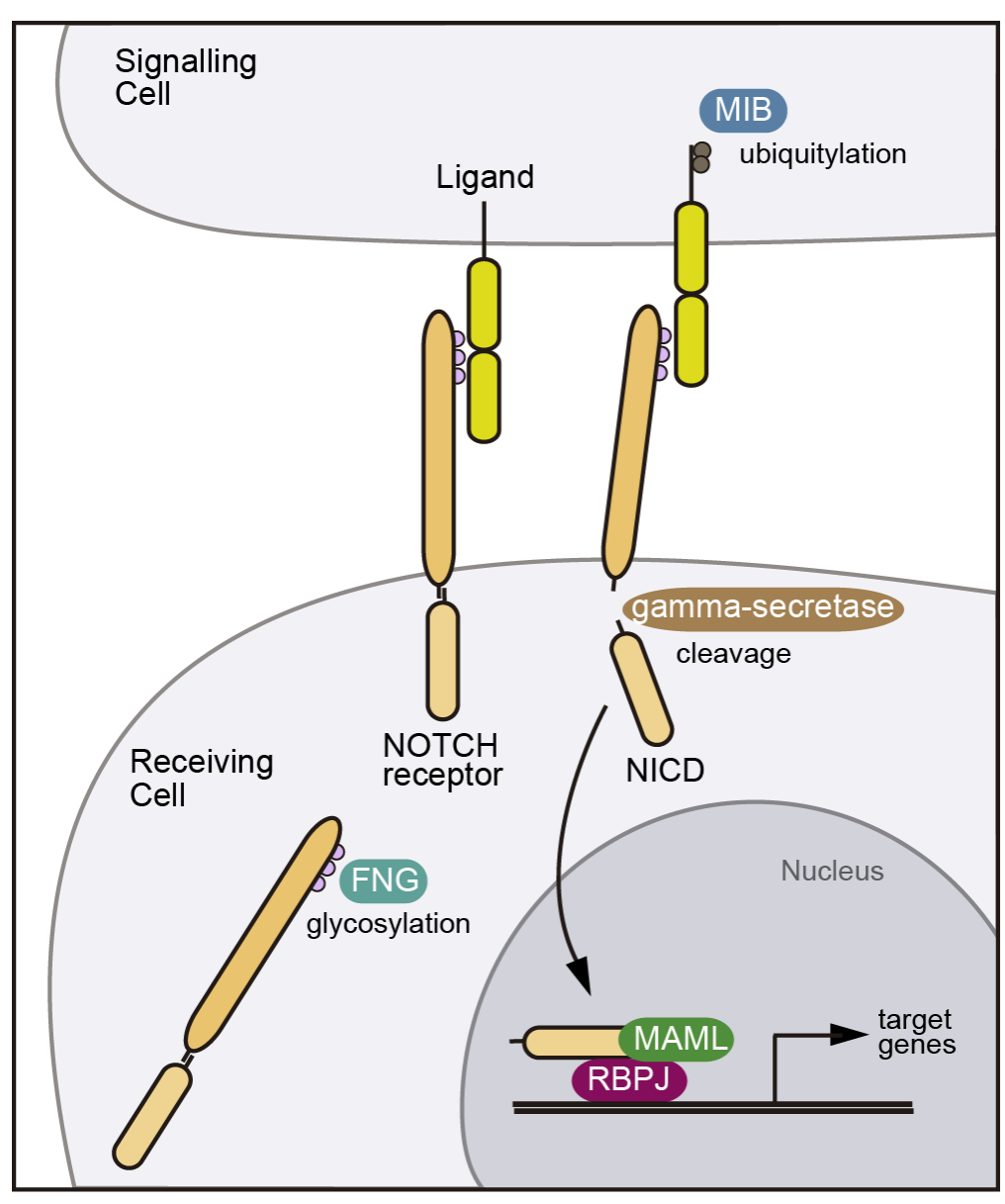




\section{Plasticity during fate specification}

As previously mentioned, the outer or inner position of blastomeres in the morula correlates with their later fate in the blastocyst. However, the repositioning of cells during the transition from morula to blastocyst (Anani et al., 2014; Watanabe et al., 2014) raised the question of how plastic are blastomeres. Given that lineage commitment is a gradual process that is not dependent on a single factor, are uncommitted blastomeres the ones that change their position to the other population? Or are committed blastomeres able to change their fate according to their location?

Two independent CDX2-GFP reporter lines, a knocked-in Cdx2-GFP fusion allele (McDole and Zheng, 2012) and a BAC transgene with a GFP inserted at the initial codon of the Cdx2 coding sequence (Toyooka et al., 2016), showed by live imaging how GFP positive cells located on the outside of the late morula can get internalised and gradually reduce GFP levels. More recently, the potential of single cells has been assessed in more detail using the CDX2-GFP fusion protein reporter in order to map the precise timing of irreversible lineage commitment (Posfai et al., 2017). In this work, the authors show that the triggering of the TE program in the blastomeres of the morula does not immediately restrict their potential. The capacity of a cell to contribute to both populations decreases at the 16-32 cell transition but, interestingly, the ability to change the lineage from preTE cells and pre-ICM cells to the opposite one is not the same. In wildtype embryos, we find CDX2-GFP ${ }^{\text {high }}$ cells that preferentially contribute to the TE and CDX2-GFPlow cells that exclusively contribute to the ICM from the early 32-cell stage. Remarkably, this plasticity changes in reconstituted embryos composed of only 32-cell stage CDX2-GFP low or CDX2GFPhigh. In the first case, cells still form both lineages, and it is not until the 64-cell stage that cells lose their ability to form TE. In contrast, embryos built with CDX2-GFPhigh cells do not develop because the cells have already lost their ability to form ICM (Posfai et al., 2017). These differences in plasticity suggest that TE is the first committed lineage in the embryo, whereas ICM cells retain a broader potential. 


\section{Capturing the first lineages in culture}

A remarkable property of the first lineages of the blastocyst is that cells at these states can be isolated and cultured on a dish under conditions that preserve their stemness and can eventually be reintroduced into live embryos and recapitulate their lineage potential. Moreover, these stem cells can be pushed to differentiate spontaneously or driven towards specific fates, thereby providing instrumental tools to dissect the molecular mechanisms operating in these lineages.

Embryonic stem (ES) cells are derived from the ICM (Evans and Kaufman, 1981; Martin, 1981), while trophoblast stem (TS) cells are derived from the TE (Tanaka et al., 1998). These stem cell populations largely maintain the potency and regulatory networks from the population they were derived from and, in chimera assays, they contribute to their lineage of origin (Beddington and Robertson, 1989; Tanaka et al., 1998). Importantly, the ease of genetic manipulation in culture has allowed to study their functional plasticity and addressing their capacity to be interconverted by changing their identity. ES cells that overexpress $C d x 2$, Gata3, Eomes, Tfap2c, or Tead4, transdifferentiate to TS-like cells (Kuckenberg et al., 2010; Nishioka et al., 2009; Niwa et al., 2005; Ralston et al., 2010). The opposite situation is found when TS cells are reprogrammed using the same strategy used to generate induced pluripotent stem cells (iPSCs); this is overexpressing Oct4, Sox2, KIf4 and c-Myc (Kuckenberg et al., 2011). Even more, cellular states preceding the first lineage choice can be maintained in culture. A transient population of ES cells that express transcripts found in 2-cell embryos has been described. Using this population or culturing ES cells in the presence of MEK and GSK3 inhibitors (2i conditions (Ying et al., 2008)) allows ES cells to expand their potency capabilities and contribute in vivo to both embryonic and extraembryonic lineages (Macfarlan et al., 2012; Morgani et al., 2013).

The culture of ES cells has revealed the coexistence of two distinct populations in the conventional heterogeneous culture conditions which differ in their pluripotent state. ES cells in a naïve state have the signature of the preimplantation epiblast, characterized by the expression of the core factors Oct4, Sox2 and Nanog as well as a series of other factors known as naïve markers such as Prdm14, Dppa3, Esrrb or Zfp42. In contrast, ES cells in a primed state have reduced expression levels of Nanog and the naïve markers, 
and are more predisposed to differentiate (Hackett and Surani, 2014; Kalkan and Smith, 2014). However, these subpopulations can also interchange their identity (Abranches et al., 2013) suggesting that they are not irreversible states and that they may coexist in an equilibrium within the pluripotent state.

Stem cell lines have provided vital tools to understand fate decisions circumventing the technical challenges of limited embryonic material. However, it is important to keep in mind that they are not completely equivalent. For instance, differences between the TE and TS cells have been reported regarding their epigenetic status (Senner et al., 2012) or the non-coding elements that regulate $C d x 2$ (Rayon et al., 2016). Furthermore, the mechanisms regulating the 3D structure of the embryo such as cell polarity or cortical tensions cannot be recreated in regular $2 \mathrm{D}$ cultures. This issue has been recently addressed with the assembly of blastocyst-like structures (blastoids) after confined culture of ES cells and TS cells (Rivron et al., 2018). This new methodology to create synthetic embryos has provided new tools to understand how a blastocyst is built and perform large-scale analysis without the limitations of working with embryos.

\section{Spatio-temporal control in development: gene regulatory elements}

A full organism is generated based on the genomic information contained in a single cell. However, the millions of cells generated from it are specialized and different from each other despite having the same genome. How is this controlled? Cells do not only have genes in its DNA, but also all the information required to regulate where, when and how much those genes have to be activated. During embryo development, different lineages and tissues are established in the body plan of the new organism. Cells will take fate decisions successively by triggering specific programmes and they will have to do it at the right time and in the right place. In the non-coding DNA, there are sequences that act as regulatory elements to orchestrate the spatio-temporal control of these gene expression programmes. 
Transcriptional regulation is mainly mediated by the action of promoters, enhancers, repressors and insulators (Symmons and Spitz, 2013). While promoters, that are located near the transcription start site, recruit RNA polymerase II and trigger transcription, they require enhancers, that can act from both proximal and distal positions, and other cisregulatory elements for full activity and to achieve spatially and temporally controlled domains of expression (Banerji et al., 1981; Catarino and Stark, 2018). The genome structures in $3 \mathrm{D}$ within the nucleus to facilitate promoters and enhancers physically interact and promote gene expression. Complex expression patterns of genes that are expressed in different tissues or at different time points during development are achieved by the combined action of several enhancers. Each element may regulate a subset of the global expression pattern of a gene whereas other enhancers may function in an additive manner (Andrey and Mundlos, 2017).

Regulation of $C d \times 2$ has been shown to be dependent on several regulatory elements during different stages in development or in TS cells (Figure 6) (Benahmed et al., 2008; Home et al., 2009; Rayon et al., 2016; Wang and Shashikant, 2007). The TEE element drives reporter expression in the TE at blastocyst stage but it is not active in TE-derived tissues of the early postimplantation embryo, such as the extraembryonic ectoderm, or in TS cells, where $C d \times 2$ is robustly expressed. In contrast, other elements located in the first intron or downstream of $C d \times 2$ are active in TS cells and in a portion of the extraembryonic compartment at E6.5 (Figure 6) (Rayon et al., 2016). This is an example of how a gene depends on different inputs in a context-dependent manner to achieve the proper level and spatio-temporal scale of expression. 

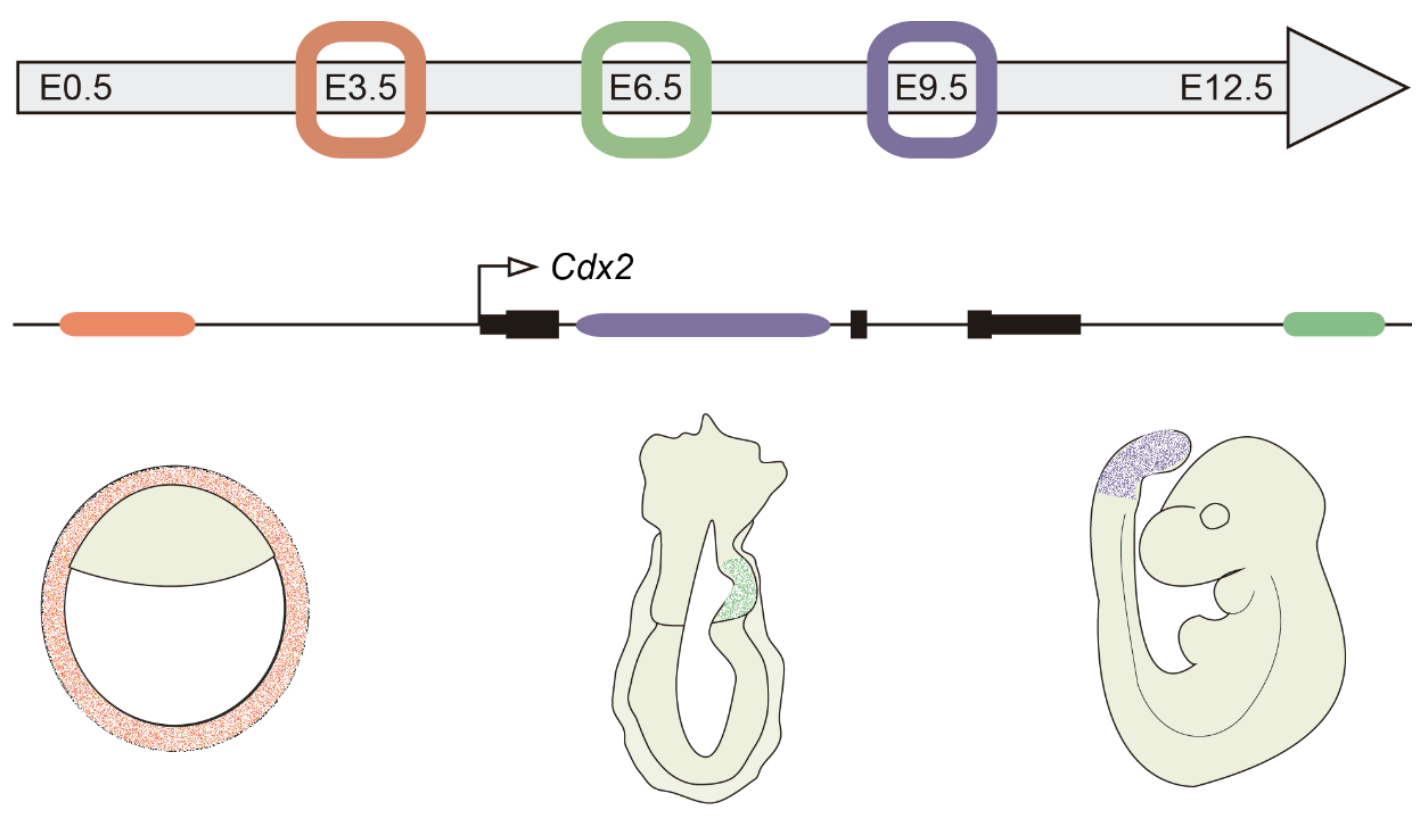

Figure 6. Regulation model of $\boldsymbol{C d} \boldsymbol{x} \mathbf{2}$. Different regulatory elements (represented in different colours) of the genomic landscape of $C d \times 2$ show enhancer activity in different regions and stages of embryo development.

Approaches to predict enhancers are based on functional reporter assays, identification of open chromatin regions or the presence of specific post-transcriptional modifications of Histone 3 such as mono-methylation of the lysine residue in position 4 (H3K4me1) or acetylation of lysine 27 (H3K27ac) (Banerji et al., 1981; Buenrostro et al., 2013; Heintzman et al., 2009; Rada-Iglesias et al., 2011). However, their identification can be challenging as they do not necessarily regulate the closest gene and they can be placed hundreds of kilobases away from their targets. Identification of regulatory elements for the main players involved in the first specifications of lineages can help to better understand the changes in gene expression and how fates are established.

Therefore, the study of the regulatory circuitry as well as the signals and inputs needed to activate specific elements can provide valuable information to unravel the spatial and temporal dynamics driving the transitions from plastic to committed populations.

Once we have decoded the key transcription factors located at the core of the first lineage programmes, how the heterogeneities arise in the embryo and how the road to cell fates is monitored are still open questions in the field. In this work, we aimed to 
understand the role of the Notch signalling pathway driving the blastomeres of the early embryo towards the specification of the first populations. 


\section{OBJECTIVES}




\section{OBJECTIVES}

The central aim of this doctoral thesis project has been to unravel how the key factors responsible for the first lineages arising during preimplantation development are acting in the embryo, and how upstream inputs regulate cell commitment. With this general objective in mind, we defined the following specific objectives:

- To study the interplay between the Notch and Hippo signalling pathways during preimplantation stages of mouse development.

- To dissect the temporal requirements of Notch and Hippo in the regulation of the trophectoderm lineage specifier CDX2.

- To assess the dynamics of the Notch pathway during preimplantation development.

- To identify novel targets and regulatory elements downstream of the input of Notch to gain insight into how signalling is acting to promote the specification of the first lineages. 


\section{MATERIALS AND METHODS}




\section{Animal experimentation}

In this work, wildtype mice, CD1 and F1 (C57BI6 x CBA), as well as mouse strains with specific modified alleles were used to perform the experiments. The different mouse lines used are listed in Table $\mathbf{1 .}$

\begin{tabular}{|c|c|}
\hline Mouse line & Reference \\
\hline CBF1-VENUS & (Nowotschin et al., 2013) \\
\hline$R b p j^{--}$ & (Oka et al., 1995) \\
\hline Tead4 & (Nishioka et al., 2008) \\
\hline$R b p j^{\text {IIOx/fIOx }}$ & (Han et al., 2002) \\
\hline Notch1 $\%$ & (Conlon et al., 1995) \\
\hline iChr-Notch-Mosaic & (Pontes-Quero et al., 2017) \\
\hline Rosa26-stop-N1ICD-ires-eGFP & (Murtaugh et al., 2003) \\
\hline$Z p 3^{\text {cre }}$ & (de Vries et al., 2000) \\
\hline Sox $2^{\text {cre }}$ & (Hayashi et al., 2003) \\
\hline Polr2a cretкIL & (Guerra et al., 2003) \\
\hline
\end{tabular}

Table 1. Mouse strains.

All the lines were maintained in heterozygosis in an outbred background. Adults were genotyped by PCR of tail-tip DNA using primers and conditions previously described for each line. For preimplantation embryos, genotyping was performed directly on individually isolated embryos after recovery, culture or antibody staining.

Mice were housed and maintained in the animal facility at the Centro Nacional de Investigaciones Cardiovasculares (Madrid, Spain) in accordance with national and European Legislation. Procedures were approved by the CNIC Animal Welfare Ethics Committee and by the Area of Animal Protection of the Regional Government of Madrid (ref. PROEX 196/14). 


\section{Embryo collection and culture}

Females from the different mouse lines or outbred wildtype CD1 were superovulated as previously described (Behringer et al., 2014), except in the case of embryos to be used for RNA-seq. For embryo culture, zygotes were collected from oviducts, treated with hyaluronidase (\#H3884, Sigma) to remove cumulus cells and cultured until the desired stage at $37.5^{\circ} \mathrm{C}, 5 \% \mathrm{CO}_{2}$, in M16 medium (\#M7292, Sigma) covered with mineral oil (NidOil, EVB). For experiments that did not require culture, embryos were collected at morula or blastocyst stage by flushing the oviduct or the uterus with M2 medium (\#M7167, Sigma) and fixed.

\section{Immunofluorescence of preimplantation embryos}

Immunofluorescence was performed as previously described (Dietrich and Hiiragi, 2007). The antibodies and dilutions used are listed in Table 2. Secondary Alexa Fluor conjugated antibodies (Life Technologies) were used at 1:1000. Nuclei were visualized by incubating embryos in DAPI at $1 \mu \mathrm{g} / \mathrm{ml}$.

\begin{tabular}{lcc}
\hline \multicolumn{1}{c}{ Antibody } & Reference & Dilution \\
\hline Monoclonal mouse anti-CDX2 & MU393-UC, Biogenex & $1: 200$ \\
\hline Rabbit monoclonal anti-CDX2 & ab76541, Abcam & $1: 200$ \\
\hline Mouse monoclonal anti-Oct4 & sc-5279, Santa Cruz Biotechnology & $1: 200$ \\
Mouse monoclonal anti-YAP & sc-101199, Santa Cruz Biotechnology & $1: 200$ \\
\hline Rat monoclonal anti-NANOG & $14-5761$, eBioscience & $1: 200$ \\
\hline Rabbit polyclonal anti-pERM & 3141, Cell Signaling & $1: 250$ \\
Rat monoclonal anti-E-Cadherin & U3254, Sigma & $1: 250$ \\
Mouse monoclonal anti-TEAD4 & ab58310, Abcam & $1: 100$ \\
Rabbit monoclonal anti-N1ICD & 4147, Cell Signaling & $1: 100$ \\
\hline Rabbit polyclonal anti-DsRed & 632496 living colors Clontech & $1: 500$ \\
\hline Goat polyclonal anti-GFP & R1091P, Acris, Origene & $1: 200$ \\
\hline Rat monoclonal anti-HA & 11867423001, Sigma & $1: 200$ \\
\hline
\end{tabular}

Table 2. Antibodies. 


\section{Imaging and quantification}

Images of antibody-stained embryos were acquired on glass-bottomed dishes (Ibidi or MatTek) with a Leica SP5, Leica SP8 or Zeiss LSM880 laser scanning confocal microscopes. The same parameters were used for imaging each experiment. Semi-automated 3D nuclear segmentation for quantification of fluorescence intensity was carried out using MINS, a MatLab-based algorithm (http://katlab-tools.org/) (Lou et al., 2014), and analysed as previously described (Saiz et al., 2016). Mitotic and pyknotic nuclei were excluded from the analysis.

For live imaging, embryos were cultured in microdrops of PBS on glass-bottomed dishes (MatTek) in an environmental chamber as described previously (Xenopoulos et al., 2015). Images were acquired with a Zeiss LSM880 laser scanning confocal microscope system using a $40 x$ objective. An optical section interval of $1.5 \mu \mathrm{m}$ was acquired per $z$-stack, every 15 minutes.

Cell tracking of 3D-movies was carried out using a TrackMate plugin in Fiji (Fernándezde-Manúel et al., 2017; Schindelin et al., 2012; Tinevez et al., 2017). The 3D reconstruction of the embryos and position of the cells was done using vTONI, a MatLab-based tool generated in the lab (Lopez-Izquierdo et al., unpublished). The shape of the embryos was fitted into an ellipse and the coordinates in $X, Y, Z$ for each blastomere were normalised to the centroid of the ellipse. The algorithm assigned an inner or outer position to each blastomere according to an established threshold, and they were manually verified. The intensity levels of VENUS fluorescent protein in each cell and time point were normalised according to the Z-position to correct the decay of signal intensity due to the distance with the objective (Saiz et al., 2016). The frequencies of the intensity levels for each embryo followed a Gaussian distribution. In order to compare different embryos, intensity levels were normalised so that the mean was 0 and the standard deviation was 1. 


\section{Fluorescent in situ hybridisation}

Fluorescent in situ hybridisation in mouse blastocysts was performed as previously described (Gasnier et al., 2013) using permeable transwells (Costar) in 24 well-plates. Blastocysts were fixed in $4 \%$ PFA at $4^{\circ} \mathrm{C}$ for $2 \mathrm{~h}$, dehydrated and then rehydrated through decreasing and increasing methanol series respectively. After permeabilisation and postfixation, embryos were pre-hybridised at $65^{\circ} \mathrm{C}$ for $1 \mathrm{~h}$. Probes were hybridised overnight at $65^{\circ} \mathrm{C}$. After washing, embryos were incubated in blocking solution with $10 \%$ calf serum and $0.5 \%$ BSA for $2 \mathrm{~h}$ at room temperature, followed by overnight incubation at $4^{\circ} \mathrm{C}$ with anti-DIG-POD (1:200). Signal was amplified using tyramides (TSA Cy3, Perkin Elmer), which form a precipitate in the presence of peroxidase that will be recognised by fluorescent molecules.

Probes to detect D//1 and Jag2 (provided by José Luis de la Pompa) were transcribed from plasmids containing the requisite cDNA.

\section{Pharmacological inhibitor treatments}

Two-cell or morula stage embryos were cultured in drops of M16 medium (\#M7292, Sigma) covered with mineral oil (NidOil, EVB) at $37^{\circ} \mathrm{C}, 5 \% \mathrm{CO}_{2}$, containing the corresponding pharmacological inhibitor or only DMSO (the solvent used for diluting both inhibitors) as control until the corresponding stage. The following inhibitors and concentrations were used: 10 or $20 \mu \mathrm{M}$ of the gamma-secretase inhibitor RO4929097 (S1575, Selleckchem) (Munch et al., 2013) and $10 \mu \mathrm{M}$ of the TEAD/YAP inhibitor Verteporfin (Sigma) (Liu-Chittenden et al., 2012).

\section{RT Quantitative-PCR}

RNA from pools of 25-30 embryos (for pharmacological inhibitor experiments) or from single embryos (for CRISPR/Cas9 editing) was isolated using the Arcturus PicoPure RNA Isolation Kit (Applied Biosystems) and reverse transcribed using the Quantitect Kit (Qiagen). RNA was isolated from ES cells with the RNeasy Mini Kit (Qiagen) and reverse transcribed using the High Capacity cDNA Reverse Transcription Kit (Applied 
Biosystems). cDNA was used for quantitative-PCR (RT-qPCR) with Power SYBR $B$ Green (Applied Biosystems) in a 7900HT Fast Real-Time PCR System (Applied Biosystems). Expression of each gene was normalized to the expression of the housekeeping genes Actin (in ES cells or pools of embryos) or 185 rRNA (in single embryos). Primers used are detailed in Table 3.

\begin{tabular}{|c|c|c|}
\hline Gene & Primer F & Primer R \\
\hline Actin & CAGAAGGAGATTACTGCTCTGGCT & TACTCCTGCTTGCTGATCCACATC \\
\hline $18 S$ rRNA & GCAATTATTCCCCATGAACG & GGCCTCACTAAACCATCCAA \\
\hline$C d \times 2$ & TCAACCTCGCCACAACСТTCCC & TGGCTCAGCCTGGGATTGCT \\
\hline Gata3 & GGGTTCGGATGTAAGTCGAG & CCACAGTGGGGTAGAGGTTG \\
\hline Oct4 & ATCAGCTTGGGCTAGAGAAGGATG & AAAGGTGTCCCTGTAGCCTCATAC \\
\hline Nanog & CTTACAAGGGTCTGCTACTGAGATGC & TGCTTCCTGGCAAGGACCTT \\
\hline Tle4 & CTGGACAGGTGGTTTGGACAA & GAGGTGAAGTCATGTTGCTGC \\
\hline Tbx3 & TGAGGTGCTCTGGACTGGAT & ACCATCCACCGAGAGTTGTG \\
\hline Prdm14 & CAACCTTGGAAACTGGCAGC & AAGCATCAAGAGGGGCCATC \\
\hline Dppa3 & GACCCAATGAAGGACCCTGAA & GCTTGACACCGGGGTTTAG \\
\hline Esrrb & GGACACACTGCTTTGAAGCA & ACAGATGTCTCTCATCTGGC \\
\hline Fgf5 & AAGTAGCGCGACGTTTTCTTC & CTGGAAACTGCTATGTTCCGAG \\
\hline Pou3f1 & TCGAGGTGGGTGTCAAAGG & GGCGCATAAACGTCGTCCA \\
\hline
\end{tabular}

Table 3. Primers sequences used for RT-qPCR assays.

\section{RNA-sequencing data analysis}

RNA-seq was performed on single morulae from the same litter. cDNA synthesis was performed using SMART-Seq Ultra Low Input RNA Kit (Clontech). Library preparation and sequencing was performed by the CNIC Genomics Unit using the Illumina HiSeq 2500 sequencer. Gene expression analysis was performed by the CNIC Bioinformatics Unit. Reads were mapped against the mouse transcriptome (GRCm38 assembly, Ensembl release 76) and quantified using RSEM v1.2.20 (Li and Dewey, 2011). Raw expression counts were then processed with an analysis pipeline that used Bioconductor packages 
EdgeR (Robinson et al., 2010) for normalisation (using TMM method) and differential expression testing. Expression data of Rbpjand Neo were used to genotype the samples. Two mutant and three control (two wildtype and one heterozygote) embryos were selected for analysis. Changes in gene expression were considered significant if associated to Benjamini and Hochberg adjusted p-value $<0.05$.

RBPJ binding motifs were located according to the consensus motif from CIS-BP database (M6499_1.02 motif) using FIMO (Grant et al., 2011). Association of RBPJ motifs to DEG was performed using BEDTOOLS (Quinlan and Hall, 2010) using a $10 \mathrm{~Kb}$ window surrounding the transcriptional start site of genes. ATAC-seq data from 8-cell stage embryos (Wu et al., 2016) was mapped to the GRCm38 assembly and integrated with the coordinates of RBPJ motifs previously detailed.

\section{Transient transgenic assay}

For the generation of transient transgenics, $\mathrm{F} 1(\mathrm{C} 57 \mathrm{BI} / 6 \times \mathrm{CBA})$ females were superovulated to obtain fertilised oocytes as described (Behringer et al., 2014). Each construct was microinjected into the pronucleus of fertilised oocytes at E0.5 at a concentration of $2 \mathrm{ng} / \mu \mathrm{l}$. Microinjected oocytes were cultured in microdrops of M16 medium (Sigma) covered with mineral oil (NidOil, EVB) at $37^{\circ} \mathrm{C}, 5 \% \mathrm{CO}_{2}$ until the morula stage.

Each fragment to be tested was amplified from mouse genomic DNA and by means of the NEBuilder HiFi DNA Assembly kit (New England Biolabs), they were cloned into a modified pBluescript vector (Yee and Rigby, 1993) containing a H2B-mRFP reporter gene under the control of the human beta-globin minimal promoter and including an SV40 polyadenylation signal. Primers for amplifying and cloning the $700 \mathrm{bp}$ Tle4-up region and the $600 \mathrm{bp} \mathrm{Tbx3-i7} \mathrm{region} \mathrm{are} \mathrm{detailed} \mathrm{in} \mathrm{Table} \mathrm{4.} \mathrm{Constructs} \mathrm{were} \mathrm{linearized} \mathrm{and}$ plasmid sequences removed before microinjection. For H2B-mRFP detection, embryos were fixed in $4 \%$ paraformaldehyde for $10 \mathrm{~min}$ at room temperature and immunostained. 


\begin{tabular}{ll}
\hline Fragment & Primers \\
\hline Tle4-up & ctatagggcgaattggagctcTTCTTTAGAGGCACCAGTC \\
& ggatccactagttctagagcggccgcATAAAGCCATTTTGCTTAACTG \\
Tbx3-i7 & ctatagggcgaattggagctcCAAGCCAGCCTCAGTCCC \\
& ggatccactagttctagagcggccgcCACACAAGCTTGCCAGCC \\
\hline
\end{tabular}

Table 4. Primers sequences for amplification and cloning Tle4-up and Tbx3-i7 regions. Lower case indicates sequence annealing to the plasmid and capital letters indicates sequence annealing to the genome.

\section{Mutagenesis}

Mutated version of Tle4-up (Tle4-up mut ${ }^{\mathrm{RBPJ}}$ ) was generated by site-directed mutagenesis (Mutagenex Inc.), changing the TGTGGGAAA binding motif to TGTccGAAA. Mutated version of Tbx3-i7 (Tbx3-i7 mut $\left.{ }^{\mathrm{RBPJ}}\right)$ was generated using QuickChange II XL SiteDirected Mutagenesis Kit (Agilent Technologies) changing CGTGGGAAA to CGTccGAAA. Lower case indicates the altered residues. Changes that abolish RBPJ binding were based on previously described mutated versions of the binding site (Tun et al., 1994).

\section{CRISPR/Cas9 genome editing}

Two guide-RNAs at $60 \mathrm{ng} / \mu \mathrm{l}$ were incubated with tracRNA (Sigma) at $240 \mathrm{ng} / \mu \mathrm{l}$ for $5 \mathrm{~min}$ at $95^{\circ} \mathrm{C}$. The hybridised gRNAs were then incubated with the Cas9 protein (PNA bio) at $30 \mathrm{ng} / \mu \mathrm{l}$ for $15 \mathrm{~min}$ at RT and microinjected into the pronuclei of (CBAxC57) F1 zygotes. sgRNAs were designed using the CRISPOR tool (http://crispor.tefor.net/) (Haeussler et al., 2016). The following guide RNAs were used: Tle4, TTAGCCTGCACTTCGAGTTA and CCCAATTCAAGGCGTTCTGT; Tbx3, TAACCCTTTAGAGATAGGCT and TACCAGAGAGGTTTCCTACT. Embryos were recovered at E2.5 and lysed in $50 \mu$ lextraction buffer from the Arcturus PicoPure RNA Isolation Kit (Applied Biosystems). Aliquots of 10 $\mu l$ were used for DNA extraction for PCR genotyping. Mosaic embryos were those where we detected both the deleted and the wildtype allele. The remaining $40 \mu$ l were used for RNA extraction for RT-qPCR. 


\section{Cell culture}

iChr-Notch-Mosaic ES cells were cultured in standard ES cell media (DMEM, Gibco) supplemented with $15 \%$ foetal bovine serum (HyClone), 1\% Glutamine, 1\% NEAA (Hyclone), 0.1\% B-mercaptoethanol (Sigma) and LIF (produced in-house) in dishes seeded with a feeder layer of mouse embryonic fibroblasts (MEFs). Cells were transfected with a Cre expressing plasmid to induce recombination using Lipofectamine 2000 (Invitrogen) for 24 hours. After recombination, cells were sorted using a Becton Dickinson FACS Aria Cell Sorter. To promote spontaneous differentiation, cells were cultured on gelatine-covered dishes for 48 hours in DMEM (Gibco) supplemented with 20\% serum, 1\% Glutamine and 0.1\% B-mercaptoethanol (Sigma).

\section{Statistics}

Statistical analyses were performed with GraphPad Prism 7 or R studio. Data are presented as means \pm s.e.m or means \pm s.d as indicated. Differences were considered statistically significant at $p$-value $<0.05$. Tests used to calculate $p$-value are detailed in the figure legends. Student's t-test was used to compare two groups. ANOVA with Fisher or Bonferroni post-test was used to compare several groups. Fisher's exact test was used to compare distributions. 
RESULTS 


\section{Convergence of Notch and Hippo pathways on $C d x 2$ regulation}

In order to understand how an embryo loses its initial plasticity to favour the appearance of the first lineages, we focused in studying the regulation of $c d x 2$, which is the first transcription factor to acquire a specific domain of expression during preimplantation development. In our group, we have previously described how Notch and Hippo converge on the TEE enhancer to promote $C d \times 2$ activation (Rayon et al., 2014). However, we still do not know how these two pathways interact to achieve this regulation, if they have redundant roles or if they are involved in different aspects of $C d x 2$ regulation.

\subsection{Effect of genetic disruption of Rbpj and Tead4 in the morula}

To study the cooperation of Notch and Hippo, we generated embryos containing different combinations of mutant alleles for $R b p j$ and Tead4; the respective transcriptional effectors of these signalling pathways (Nishioka et al., 2008; Oka et al., 1995). Mutant homozygotes for both TFs (double knockout) could not be recovered at blastocyst stage (Rayon et al., 2014), suggesting that they died before this stage and showed an exacerbated phenotype compared to single mutant for any of the genes (Nishioka et al., 2008; Oka et al., 1995; Yagi et al., 2007). We therefore decided to check earlier, at morula stage (E2.5), recovering double mutant embryos at expected Mendelian ratios (Figure 7). Therefore, loss of Hippo and Notch show an additive effect before the blastocyst stage.

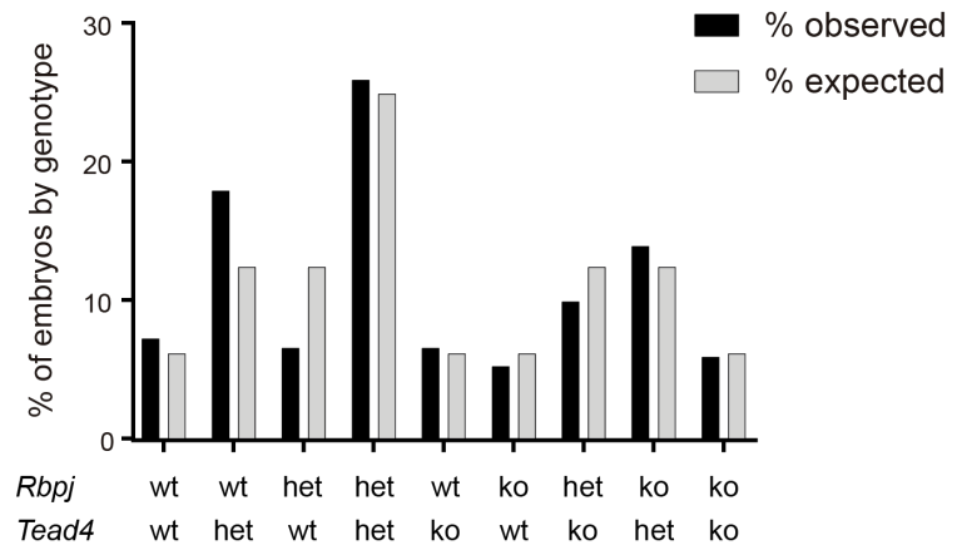

Figure 7. Distribution of embryos by genotype. Percentage of recovered and expected embryos in different Rbpjand Tead4 allelic combinations ( $\mathrm{n}=150$ embryos). 


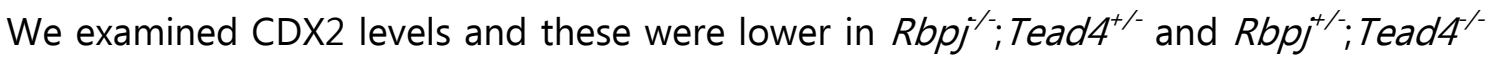
morulae but it could still be detected. However, we did not detect any CDX2 expression in double knockout embryos ( $R b p j^{\prime-} ; T_{e a d 4} /$ ), although the pluripotent marker OCT4 was expressed (Figure 8).

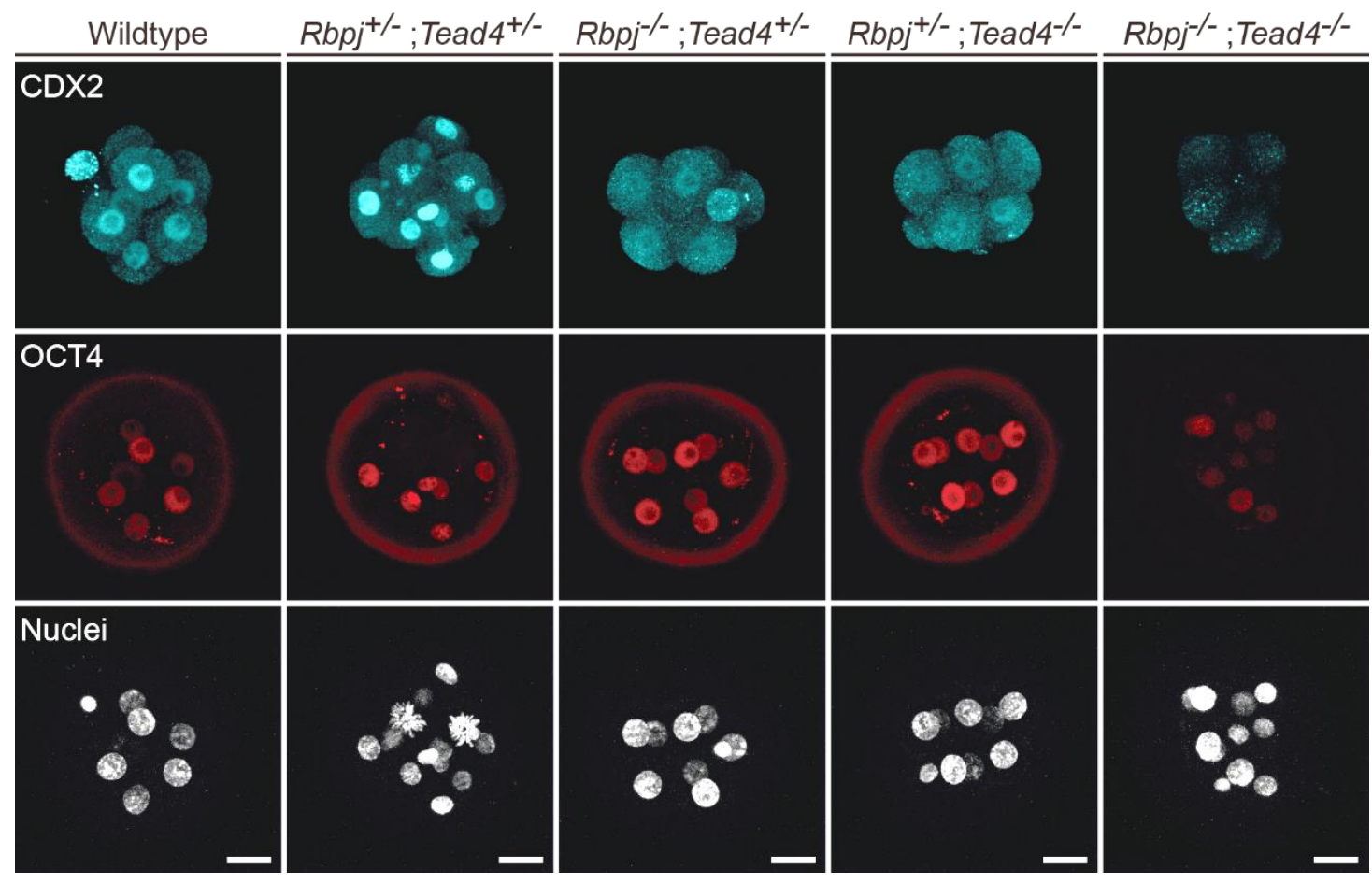

Figure 8. CDX2 depends on Rbpj and Tead4 inputs. Maximal projections of confocal images after immunostaining for CDX2 and OCT4 in different combinations of wildtype and mutant alleles for Rbpj and Tead4 at E2.5. Nuclei were stained with DAPI. Scale bars, $20 \mu \mathrm{m}$.

Compaction of blastomeres and polarisation of outer cells are critical events needed for the onset of CDX2 in the morula (Ralston and Rossant, 2008; Wu et al., 2010). We therefore examined if the absence of CDX2 in the double Rbpj;Tead mutants could be due to a defect in these processes. We examined the expression of E-cadherin and phospho-ERM as markers of cell-cell adhesion and apical polarity. No differences in the distribution or intensity of these markers were observed in any of the allelic combinations, including $R b p j^{\%} ;$ Tead $^{-/}$embryos (Figure 9). Thus, disruption of Rbpjand Tead4 does not affect compaction or cell polarisation but does result in loss of initiation of CDX2 expression. 


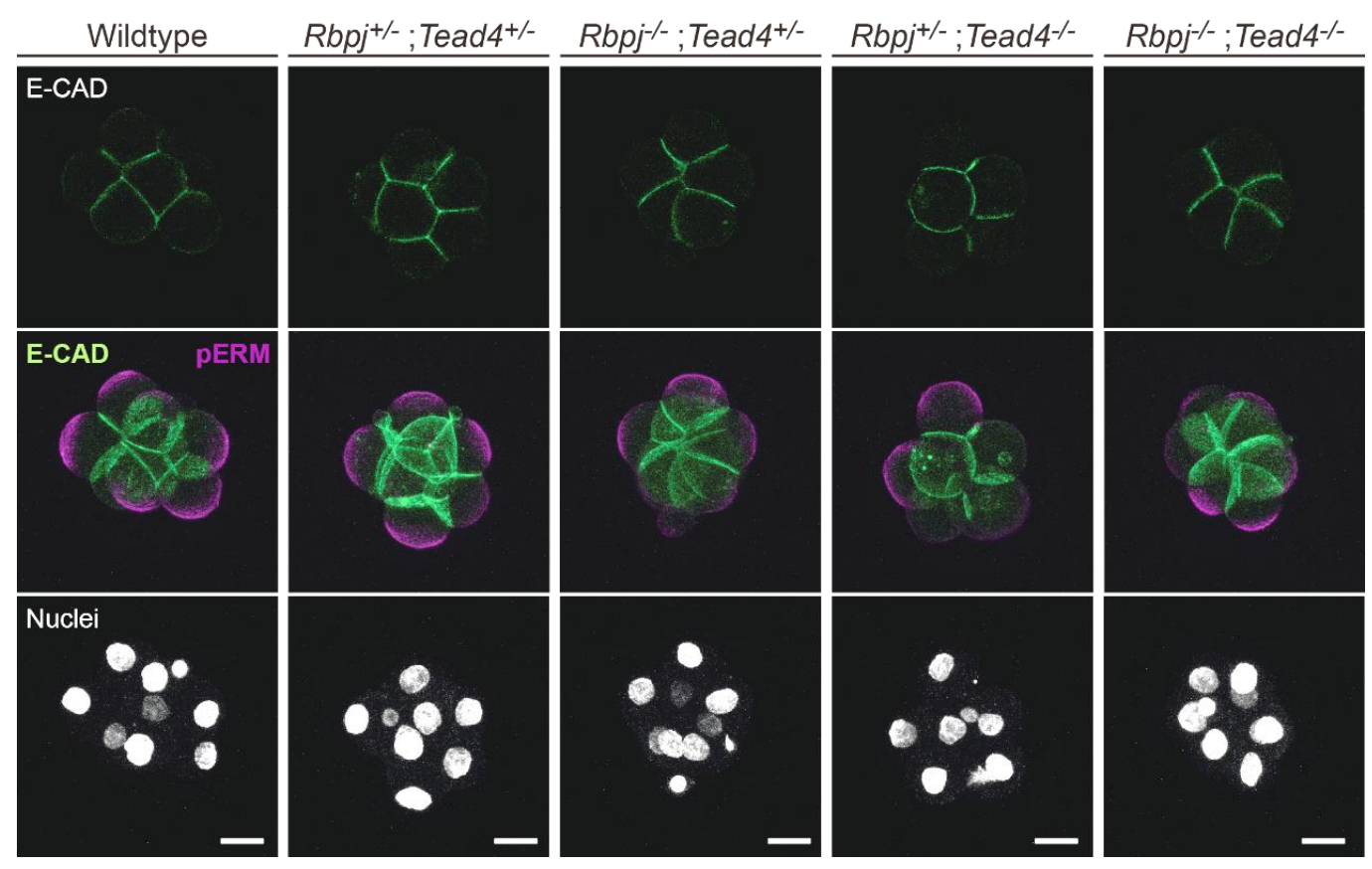

Figure 9. Lack of Rbpj and Tead4 does not affect compaction or polarisation. Optical sections (top panel) and maximal projections (middle and bottom panels) of confocal images after immunostaining for E-Cadherin and phospho-ERM in different combinations of wildtype and mutant alleles for Rbpj and Tead4 at E2.5. Nuclei were stained with DAPI. Scale bars, $20 \mu \mathrm{m}$.

\subsection{Imaging of CDX2, YAP and NOTCH activity during preimplantation development}

The expression of CDX2 and the coactivators YAP and N1ICD (the intracellular domain of Notch) is restricted to the TE of the blastocyst, while in the morula they show a more heterogeneous pattern (see Figure 5) (Nishioka et al., 2009; Rayon et al., 2014; Strumpf et al., 2005). To better understand the contributions of each of the Notch and Hippo pathways to CDX2 expression, we examined the expression of the three components in both morula and blastocyst stage. To study the behaviour of the Notch pathway we used a mouse line carrying a CBF1-VENUS transgene that faithfully reports the activation state of the pathway (Nowotschin et al., 2013). This reporter line contains multiple RBPJ (CBF1) binding sites driving the expression of a nuclear-targeted VENUS fluorescent protein. In the cells where the Notch pathway is active, NICD translocates into the nucleus and binds to the RBPJ binding sites to promote VENUS expression. The reporter is active in most of the cells of the morula to be progressively restricted to the TE in the blastocyst. The 
pattern of N1ICD, the active form of the Notch1 receptor, coincides with the reporter being localised in the TE in the blastocyst (Rayon et al., 2014) and being expressed heterogeneously in the morula (Figure 10).

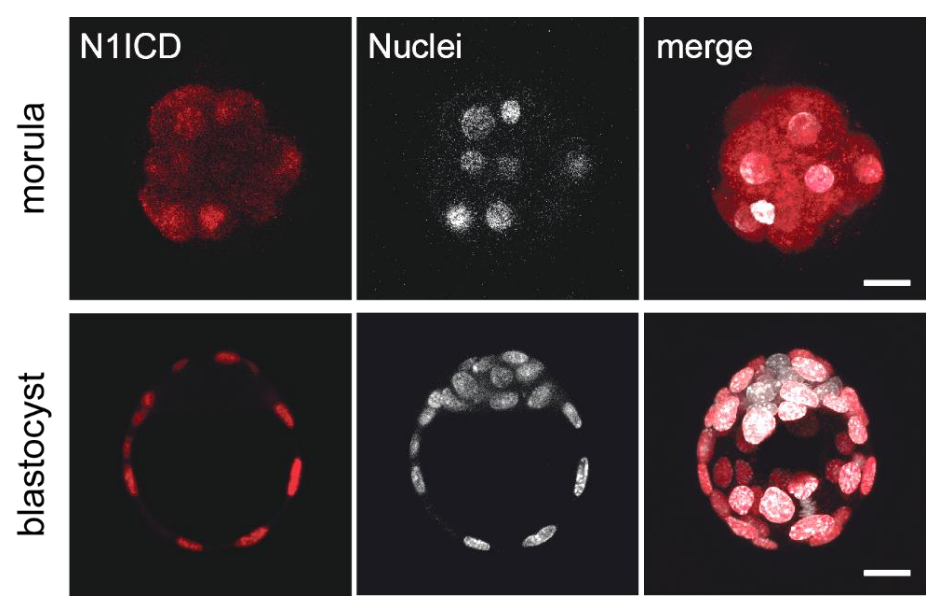

Figure 10. The Notch pathway is active in the preimplantation embryo. Optical sections (left and middle panel) and maximal projections (right panel) in the morula and blastocyst after immunostaining for N1ICD. Nuclei were stained with DAPI. Scale bars, $20 \mu \mathrm{m}$.

We performed immunostaining for YAP and CDX2 in morulae and blastocysts from the CBF1-VENUS reporter line, and then correlated expression in single cells between the three components. Nuclear YAP was detected preferentially in outer cells, presumably polarised blastomeres, whereas CBF1-VENUS and CDX2 were detected in both inner and outer cells of the morula. In the blastocysts, the three markers were restricted to nuclei of the TE (Figure 11A). We quantified nuclear intensity levels of expression using MINS, a Matlab based segmentation tool (Lou et al., 2014), and found that VENUS and YAP both correlated positively with CDX2 at morula and blastocyst stages (Figure 11B-C). Interestingly, there was no correlation between VENUS and YAP in the morula, suggesting that the two pathways are independent from each other at this stage (Figure 11B). At blastocyst stage, VENUS and YAP showed a positive correlation although weaker than the correlation of either of them with CDX2 (Figure 11C). If the levels of the three markers were taken into account simultaneously, the coefficient of correlation increased both in morula (Figure 11D) and blastocyst (Figure 11E), indicating that the combination of Notch and Hippo pathways better explained CDX2 expression than any of them individually. 
A
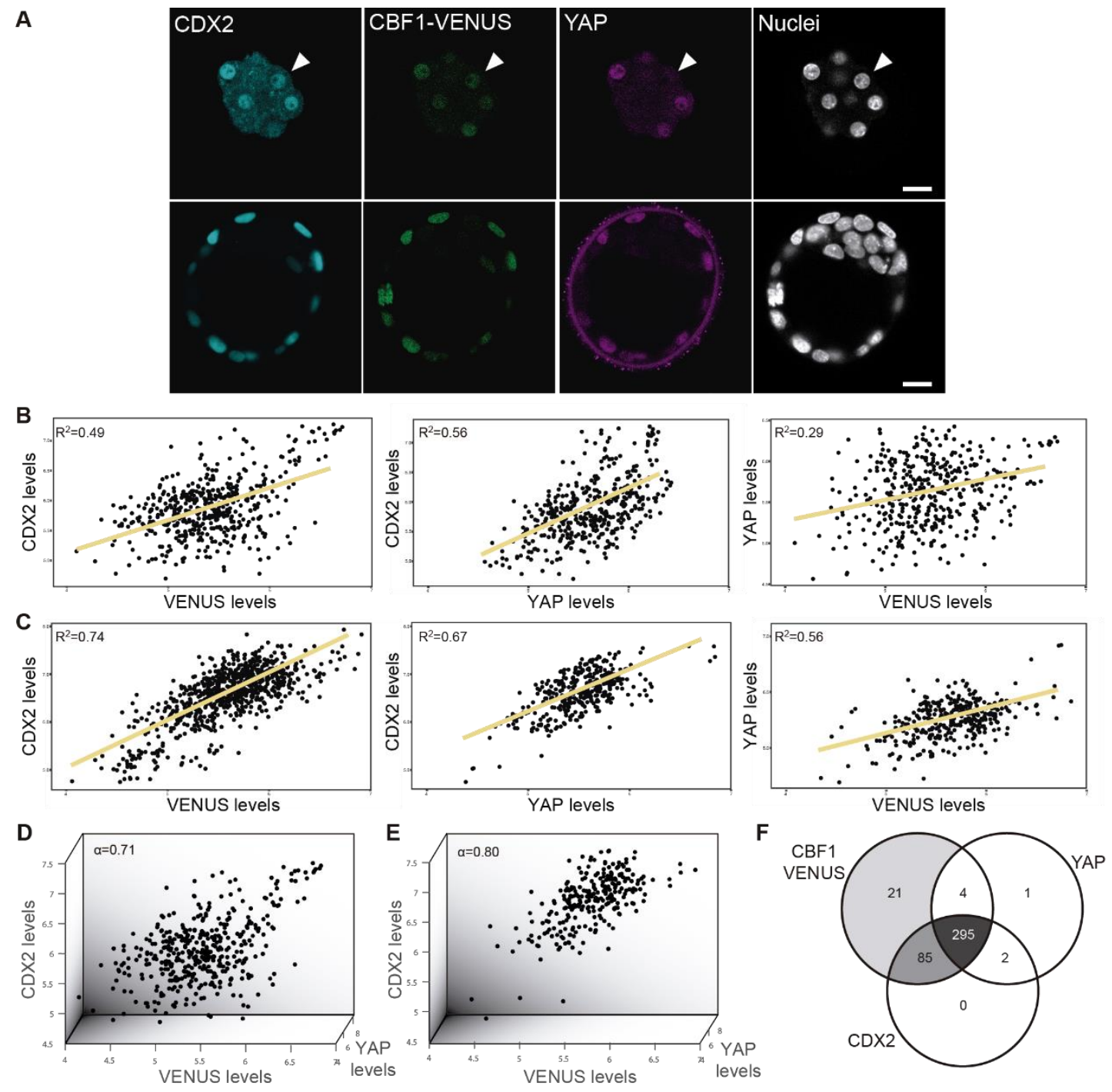

Figure 11. CDX2 expression relies on the input from Notch and Hippo signalling pathways. (A) Optical sections of confocal images after immunostaining for CDX2 and YAP in the CBF1-VENUS reporter line at morula (upper row) and blastocyst (lower row) stage. Fluorescent VENUS reporter is directly detected. Arrowheads indicate a cell positive for CDX2 and VENUS, but negative for nuclear YAP. Nuclei were stained with DAPI. Scale bars, $20 \mu \mathrm{m}$. (B-C) Pairwise correlations of single cell fluorescence intensity levels for CDX2, VENUS and YAP from embryos at morula (B) or blastocyst (C) stage. Pearson correlation $\left(R^{2}\right)$ is indicated for each correlation. (D-E) Three-way correlations of single cell fluorescence intensity levels for CDX2, VENUS and YAP from embryos at morula (D) and blastocyst (E) stage. Cronbach Alpha $(\alpha)$ to measure internal consistency reliability among the three variables is indicated. (F) Venn diagram showing number of positive cells for CBF1-VENUS, YAP and CDX2 at morula stage. $\mathrm{n}=415$ blastomeres from 28 embryos (morula stage); $\mathrm{n}=428$ blastomeres from 6 embryos (blastocyst stage). 
In most cases, individual nuclei from morulae were positive for the three markers. However, we found some cases in which nuclei were positive for CBF1-VENUS and CDX2, but negative for YAP (Figure 11A, arrowhead). We therefore analysed all morulae to determine the distribution of cells positive for each combination of markers. We observed that Notch was active in most of the cells at this stage and confirmed that the majority of blastomeres were triple positive (295 blastomeres, 72.3\%, Figure 11F). Moreover, the population represented by cells that were only positive for CBF1-VENUS and CDX2 was noteworthy (85 blastomeres, 20.8\%). However, we rarely found cells expressing YAP and CDX2, but not VENUS (Figure 11F). Interestingly, all positive cells for CDX2 were positive for either CBF1-VENUS or YAP, suggesting that at least one of both pathways needs to be active to induce CDX2 expression. Together, these results show that Notch and Hippo are responsible for CDX2 expression and suggest that they are acting in an independent manner from one another.

\section{Do Notch and Hippo have a redundant role on $C d x 2$ expression?}

The correlation analysis between CBF1-VENUS and YAP levels in single blastomeres indicated a possible independent role of Notch and Hippo pathways in the regulation of CDX2. However, we do not know if they act redundantly or if the lack of one can be compensated by increased activity of the other in regulating $C d \times 2$. Given that the Hippo pathway is the major regulator of $C d \times 2$ expression in the blastocyst, we assessed if forced activation of the Notch pathway would be sufficient to compensate and restore CDX2 levels in a Tead4 null background. To do so, we crossed the Tead4 mutant allele with a mouse line that conditionally overexpresses the coactivator N1ICD linked to a GFP reporter under the Rosa26 promoter (Rosa26-stop-N1ICD-ires-eGFP) (Murtaugh et al., 2003), and used a mouse line carrying a maternal Sox2-Cre allele to recombine it in oocytes (Hayashi et al., 2003). Although there is a certain degree of mosaicism in embryos resulting from this cross (mean of $87 \%$ of GFP+ cells in recombined blastocysts), we observed a significant increase in CDX2 intensity levels in N1ICD-GFP, Tead4 ${ }^{-1}$ as compared to Tead4 ${ }^{-}$embryos (Figure 12). However, embryos did not progress to the blastocyst stage as occur in Tead4 mutant embryos (Nishioka et al., 2008; Yagi et al., 
2007). Thus, while Notch is able to positively regulate CDX2 in the absence of Tead4 transcriptional input, it is not sufficient on its own to rescue the morphological defects due to the lack of Tead4. Again, these results suggest that Notch and Hippo act independently and do not have a redundant role during preimplantation development.

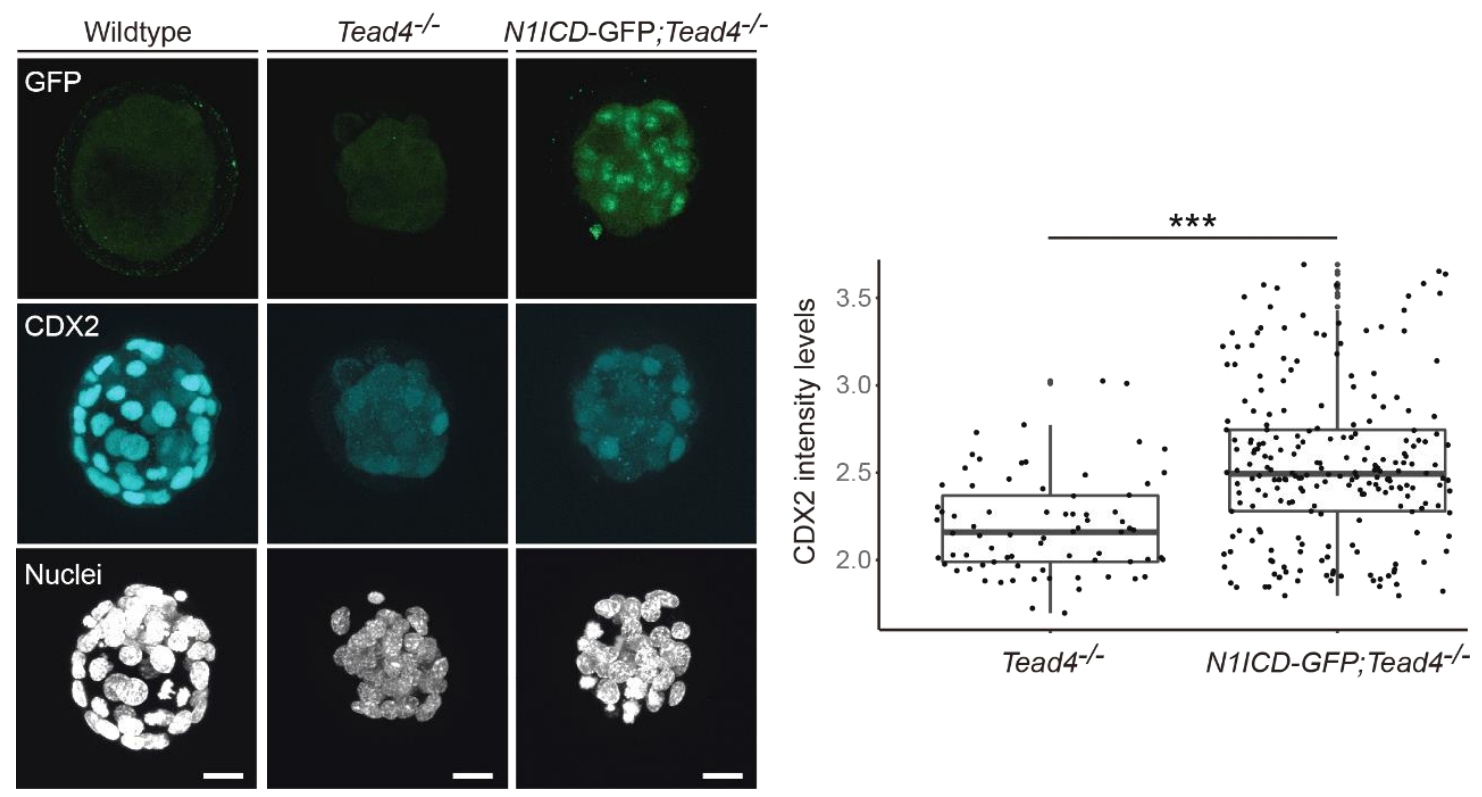

Figure 12. Overexpression of N1ICD does not fully rescue Tead4 null phenotype. Maximal projections of confocal images after immunostaining for CDX2 and GFP in wildtype, Tead $4^{\prime}$, and N1ICD-GFP; Tead $4^{\%}$ embryos. Quantification of CDX2 intensity levels in Tead4\% $\left(n=75\right.$ blastomeres from 2 embryos) and N1ICD-GFP; Tead4\% ${ }^{-1}(n=224$ blastomeres from 5 embryos) embryos. ${ }^{* *} p<0.001$ by Student's t-test.

\section{Temporal modulation of Notch and YAP inhibition}

To better understand how parallel signalling pathways drive $C d x 2$ expression, we assessed temporal differences in the regulation of $C d x 2$ expression by Notch and Hippo. To do so, we took advantage of pharmacological compounds that allow inhibition of these pathways in a temporal-controlled manner. We used RO4929097 (RO), a gammasecretase inhibitor that impedes the release of the NICD, to block the Notch pathway (Munch et al., 2013), and Verteporfin to disrupt YAP-TEAD4 interaction (Liu-Chittenden et al., 2012). We treated wildtype embryos in two different time-windows: from the 2-cell up to morula stage, and from morula to blastocyst stage. As a control, we cultured 
embryos with DMSO, the solvent used for diluting both inhibitors. After treatment, gene expression was analysed by RT-qPCR in pools of 25 embryos. In the early time-window, from 2-cell to morula stage, $C d \times 2$ was downregulated when Notch was blocked while there was no change when the Hippo pathway was altered (Figure 13A). Interestingly, we observed the opposite when we altered the pathways from morula to blastocyst. $C d x 2$ expression was reduced when YAP-TEAD4 activity was blocked (Figure 13B) but not by inhibition of the Notch pathway. These results indicate that, although both signalling pathways cooperate to regulate $C d x 2$, they do not act redundantly but sequentially to fine tune $C d \times 2$ levels in a stage specific way. Neither the TE-related marker Gata3, nor the pluripotent genes Oct4 and Nanog were significantly changed after Notch or YAP inhibition in any of the time-window treatments, indicating that $C d \times 2$ is the main target of the pathways during preimplantation development.

A
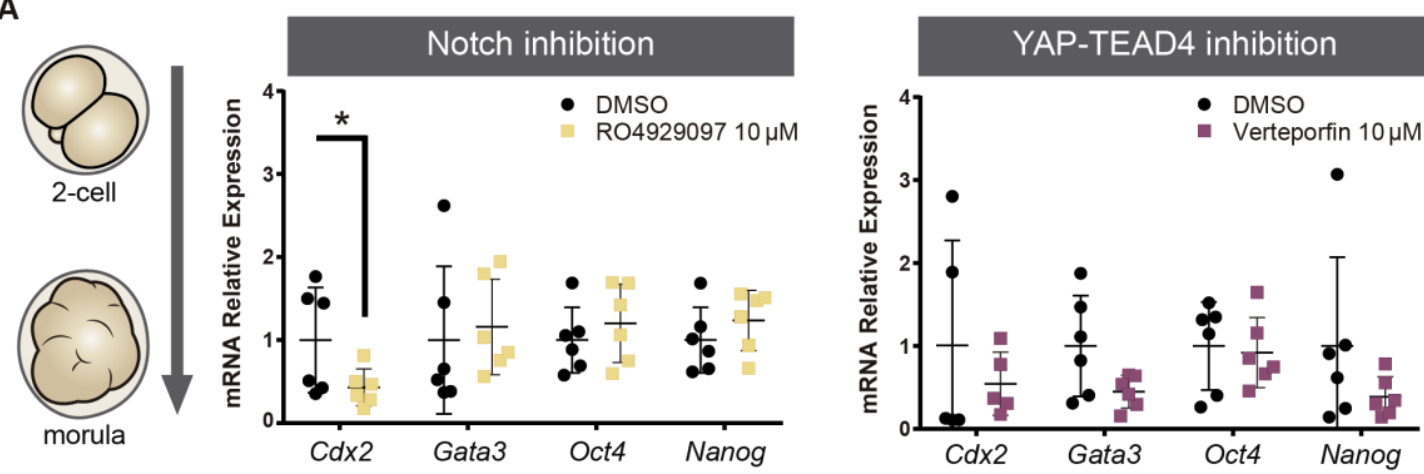

B
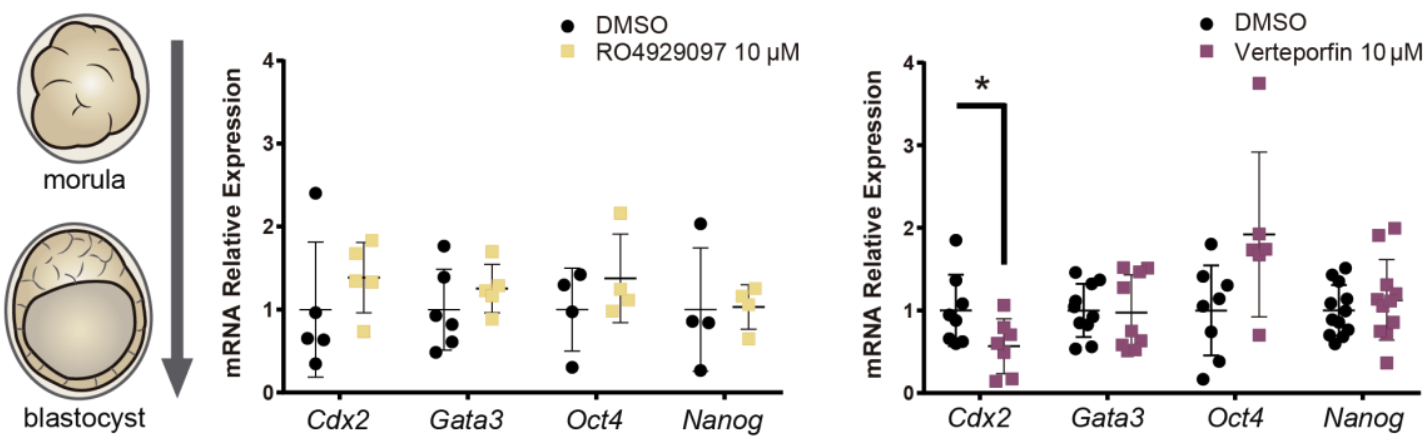

Figure 13. Notch and Hippo sequentially pattern $\boldsymbol{C d} \mathbf{x} 2$. Relative expression of $C d x 2$, Gata3, Oct4 and Nanog in pools of 25 embryos after treatment with R04929097 to inhibit Notch pathway (left) or Verteporfin to inhibit YAP-TEAD4 interaction (right). Treatments were performed from the 2-cell to morula stage $(A ; n=6)$ or from morula to blastocyst stage ( $B$; Notch inhibition, $n=4-6$; YAP-TEAD4 inhibition, $n=6-11$ ). Pools of embryos treated with DMSO were used as controls. Data are means \pm s.d. * $p$-value $<0.05$ by Student's $t$ test. 


\section{Notch regulates the early phase of $C d \times 2$ expression.}

Next, we wanted to confirm the early requirement of Notch input using genetic loss of function models. We recovered early (8-16 cells) and late (17-32 cells) morulae and analysed CDX2 expression in wildtype and $R b p j^{/-}$embryos (Figure 14). We quantified CDX2 positive cells in individual embryos and found that $R b p j^{--}$early morulae had a significantly lower number compared to wildtype embryos (Figure 14A). In contrast, we did not observe differences in late morulae (Figure 14B).

A
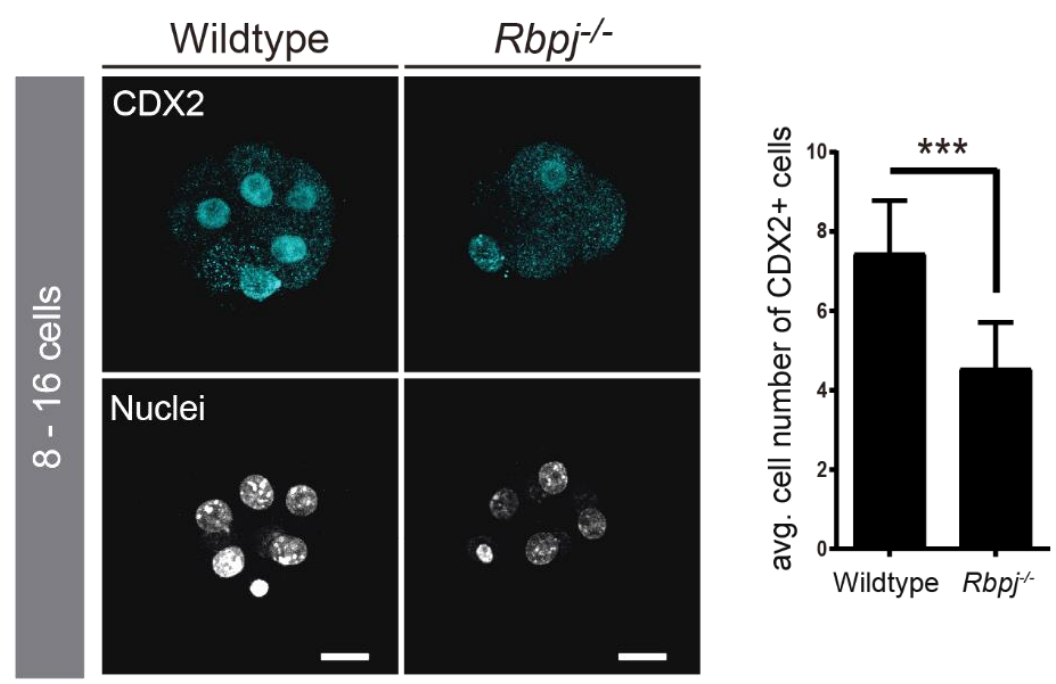

B
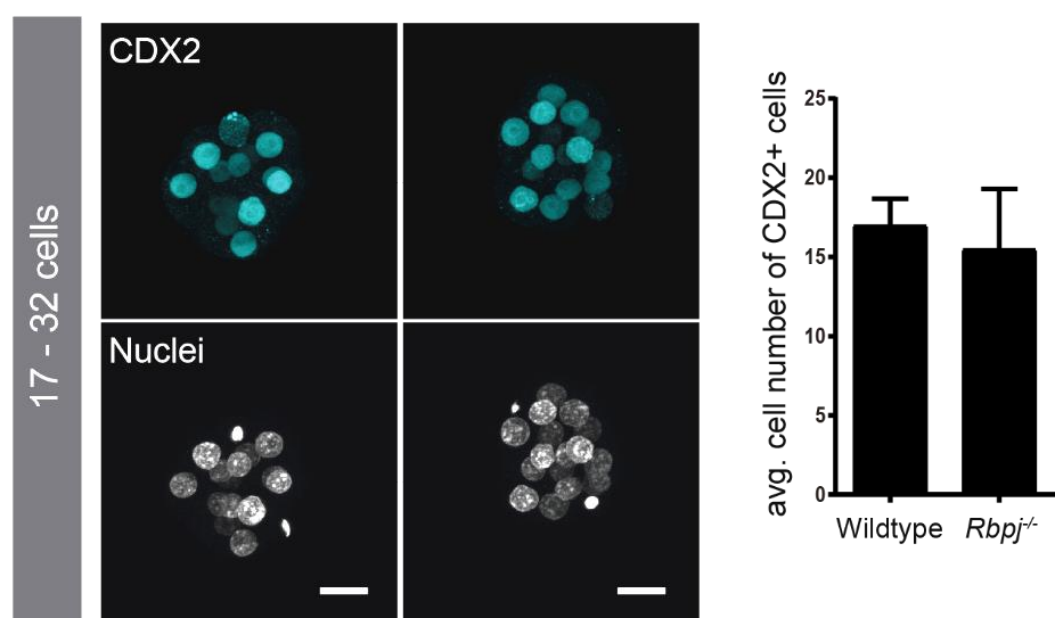

Figure 14. CDX2 decreases in Rbpj mutant early morulae. Optical sections of confocal images after immunostaining of CDX2 in wildtype and $R b p j^{--}$early $(\mathrm{A})$ and late (B) morulae. Right panels show quantification of number of CDX2 positive cells in early morulae ( $\mathrm{A} ; \mathrm{n}=11$ embryos) and late morulae ( $\mathrm{B}$; wildtype, $\mathrm{n}=4$ embryos; $R b p j^{-/}$ , $\mathrm{n}=5$ embryos). Nuclei were stained with DAPI. Scale bar, $20 \mu \mathrm{m}$. Data are means \pm s.e.m. ${ }^{* *} p<0.001$ by Fisher's exact test. 
The same observations were obtained when we analysed embryos mutant for the pathway receptor Notch1 (Conlon et al., 1995). Notch $1^{-1}$ early morulae (8-16 cells) showed a reduction in the number of CDX2 positive cells compared to wildtype early morulae (Figure 15A), but late morulae (17-32 cells) did not present any differences (Figure 15B). These observations demonstrate that Notch1 is the main player of the Notch pathway during preimplantation development and its loss recapitulates Rbpj loss of function effects.

A
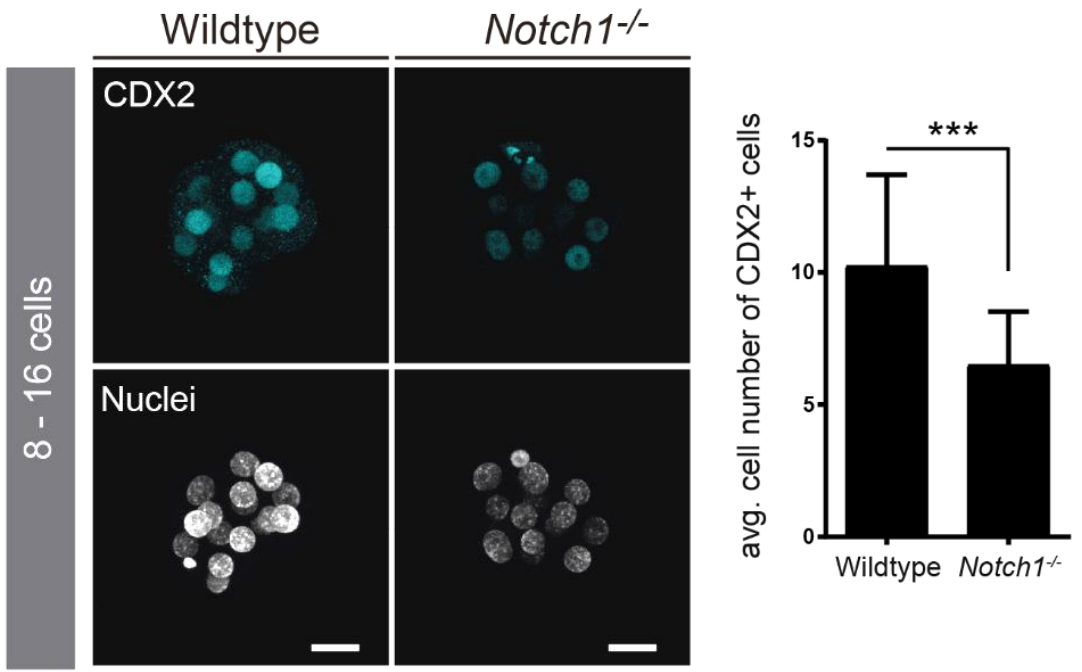

B
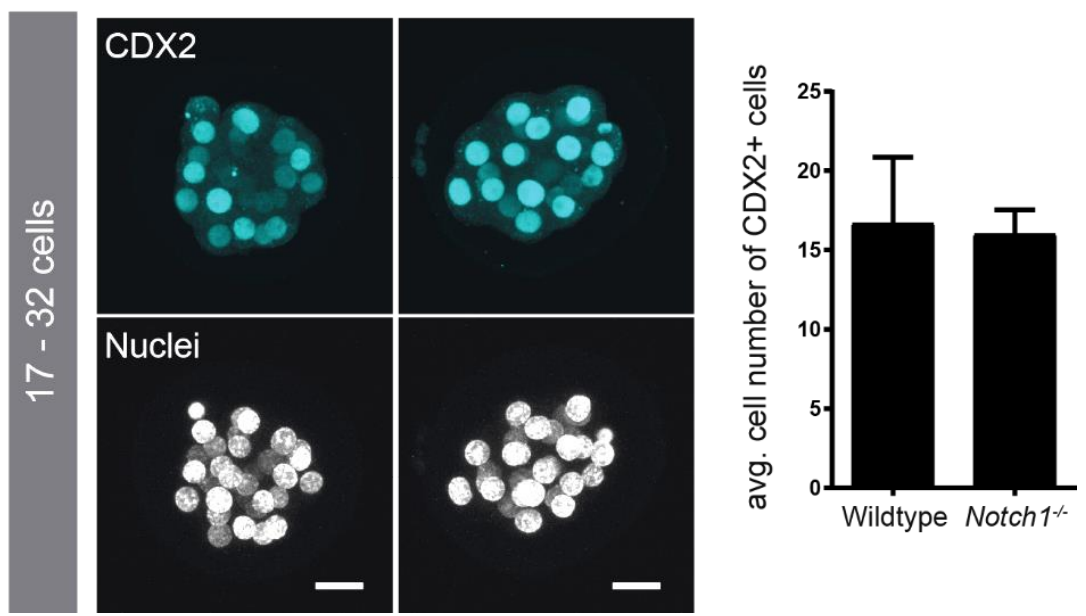

Figure 15. CDX2 decreases in Notch1 mutant early morulae. Optical sections of confocal images after immunostaining of CDX2 in wildtype and Notch1 ${ }^{\%}$ early $(A)$ and late (B) morulae. Right panels show quantification of the number of CDX2 positive cells in early morulae $(A ; n=11)$ and late morulae ( $B$; wildtype, $\left.n=5 ; \operatorname{Notch1}^{-1}, n=3\right)$. Nuclei were stained with DAPI. Scale bars, $20 \mu \mathrm{m}$. Data are means \pm s.e.m. ${ }^{\star \star *} p<0.001$ by Fisher's exact test. 
Together, these results show that there is an earlier requirement for Notch than for Hippo in the regulation of $C d x 2$, and that both pathways exert non-redundant roles. Our observations suggest a model where Notch regulates the onset of $C d x 2$ expression, and Hippo subsequently maintains restricted expression at later stages.

\section{Maternal contribution of $R b p j$ is not necessary for $C d x 2$ expression}

Similarly to our observations in late Rbpj mutant morulae, previous analysis at blastocyst stage showed that the number of CDX2 positive cells did not change between wildtype and $\mathrm{Rbpj}^{- \text {- }}$ blastocysts and that the levels of CDX2 were subtly decreased (Rayon et al., 2014). To investigate if the maternal contribution of Rbpj provided in the oocyte could have a role and compensate for the lack of zygotic gene expression in Rbpj mutant embryos, we assessed the effect of loss of maternal Rbpj. To test this, we used a mouse line carrying loxP sites flanking the exons coding the DNA binding domain of RBPJ to conditionally knockout the gene (Han et al., 2002), and a female germline-specific Zp3Cre line (de Vries et al., 2000). $R b p j^{\text {delfflox }}, Z p 3^{\text {Crel+t}}$ females were crossed with $R b p j^{+/-}$males to generate embryos lacking both maternal and zygotic $R b p j\left(\mathrm{MZ} R b p j^{\prime-}\right)$ as well as littermates deficient in maternal $R b p j$ but heterozygous for the zygotic allele (maternal $R b p j^{\prime \prime}$ ) (Figure 16A).

Blastocysts showed normal pattern of CDX2 expression in both maternal and maternalzygotic Rbpj mutants, indicating that removal of $R b p j$ from the oocytes does not exacerbate the effect of loss of zygotic mutant Rbpj on CDX2 expression (Figure 16B). 
A

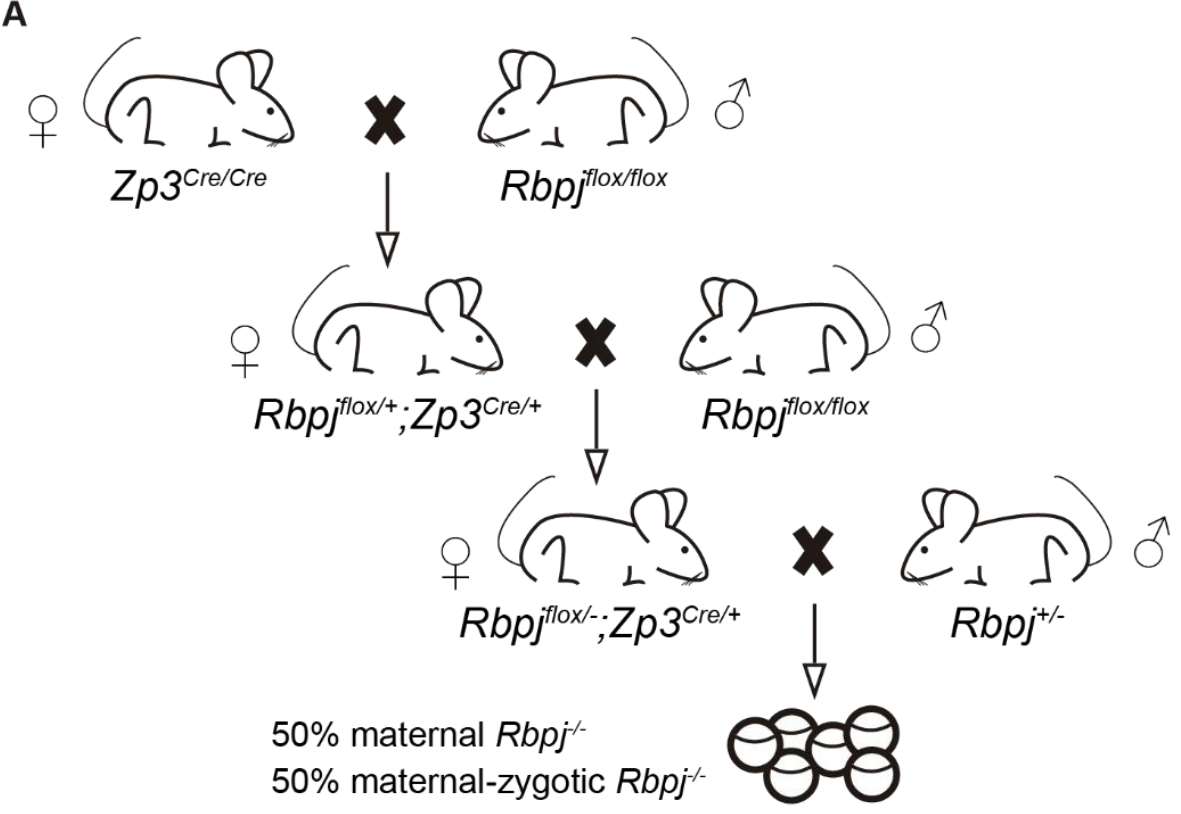

B
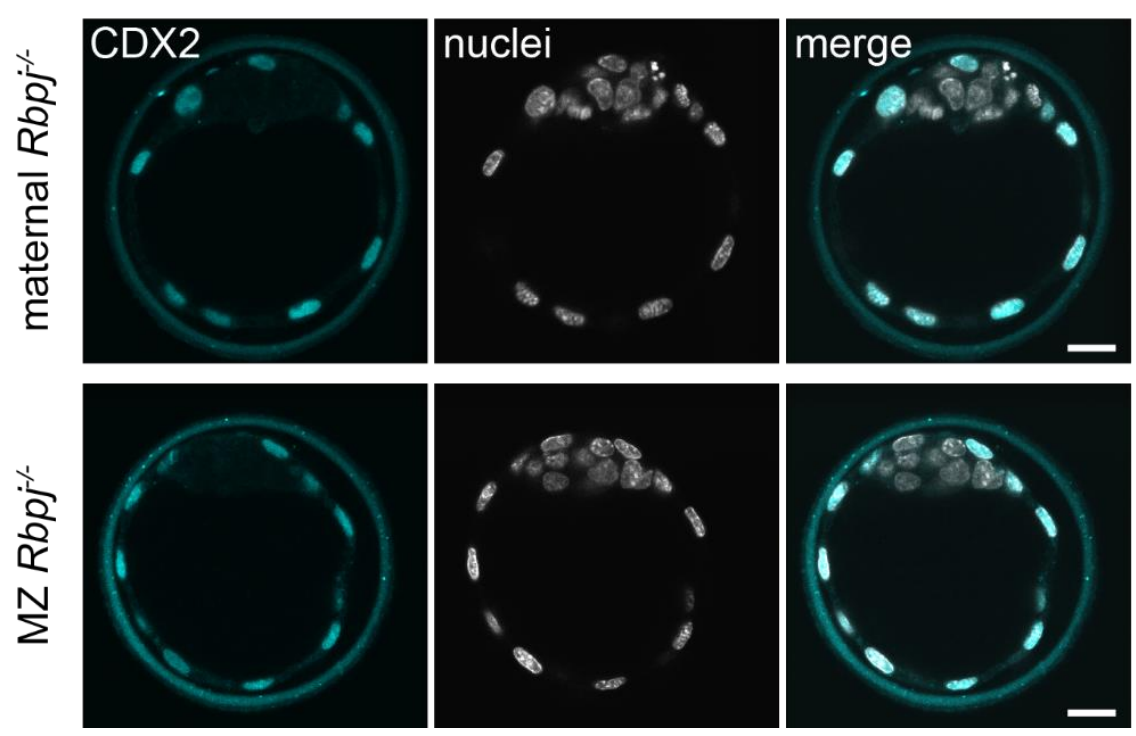

Figure 16. Removal of maternal and zygotic Rbpj does not exacerbate CDX2 decrease. (A) Schematic representation of mouse crosses to conditionally delete $R b p j$ from oocytes using $Z p 3^{C r e}$ and $R b p j^{\text {flox }}$ mice. (B) Optical sections of confocal images after immunostaining of CDX2 in maternal $R b p j^{--}$and maternal-zygotic (MZ) $R b p j^{-}$. Nuclei were stained with DAPI. Scale bars, $20 \mu \mathrm{m}$. 


\section{The Notch pathway is heterogeneously active in the embryo starting at the 4-cell stage}

After the above findings revealing a requirement of the Notch pathway when the TE program is first triggered, we decided to investigate when Notch is first active, using the CBF1-VENUS reporter mouse line as a readout of the activity of the pathway. We collected embryos from the CBF1-VENUS line and found that the reporter was first detected in 4-cell embryos, albeit at lower levels than at later stages (Figure 17A). The number of VENUS positive cells was variable among embryos examined, and a third of them had no positive cells (7 out of 20) (Figure 17C). This suggests that the onset of Notch pathway activation is indeed occurring at this stage. As a general rule, from the 4cell stage and before compaction, the number of positive blastomeres increased with the total number of cells per embryo (Figure 17B-C). Upon compaction, most of the cells were VENUS positive and the activity of the reporter was later restricted to the outer TE cells once the blastocyst is formed (Figure 11A).

\section{Notch activity dynamics in the morula to blastocyst transition}

In order to follow the dynamics of the reporter and determine how restriction of Notch activity is achieved during preimplantation stages, we performed live imaging during 24 hours of embryos at the transition from compacted morula ( 16-cells) to the early blastocyst stage (Figure 18A, Movie 1). We collected 3D + time (4D) imaging data of CBF1-VENUS embryos and selected seven of them for processing and analysis. Cell tracking for each embryo resulted in the generation of lineage trees that included a cell at 0 time point and all of its descendants (Figure 18B). 
A
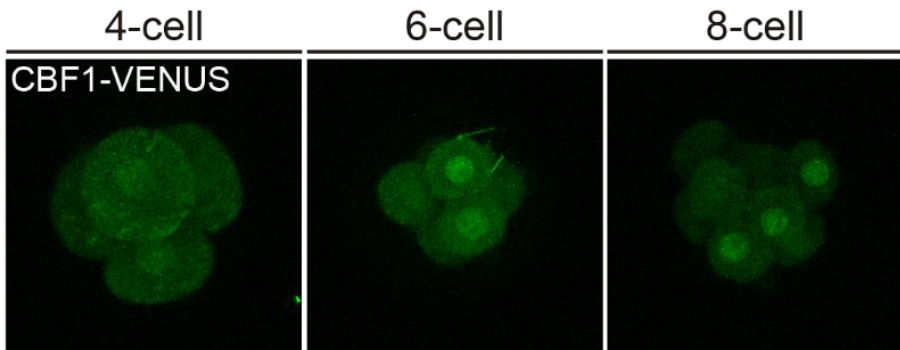

compacted
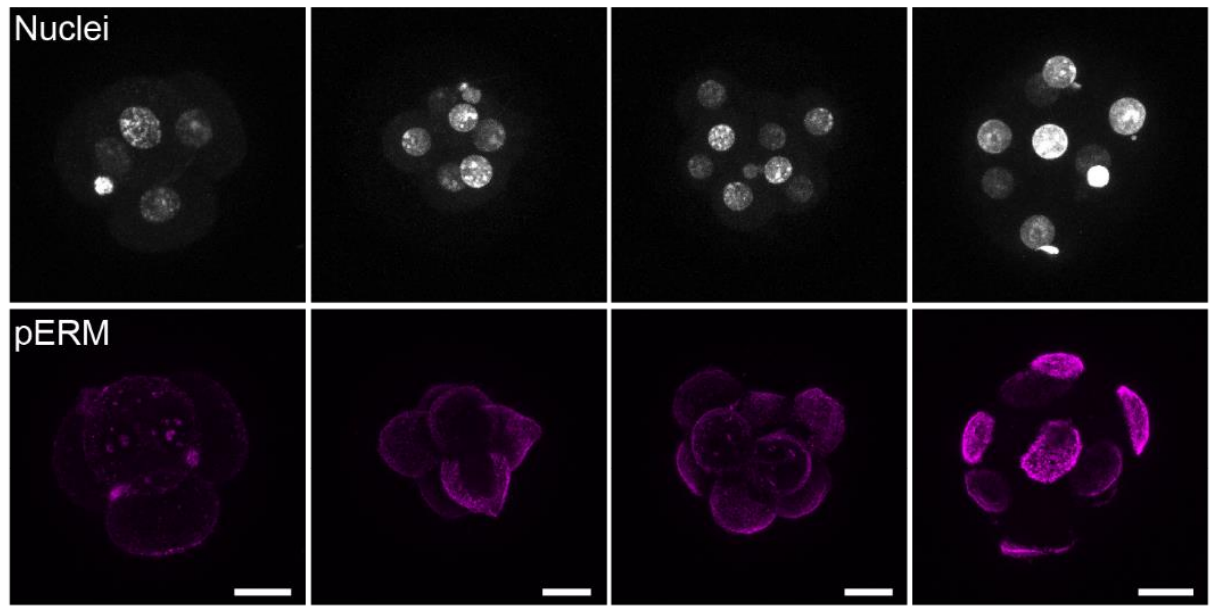

B

C

VENUS +
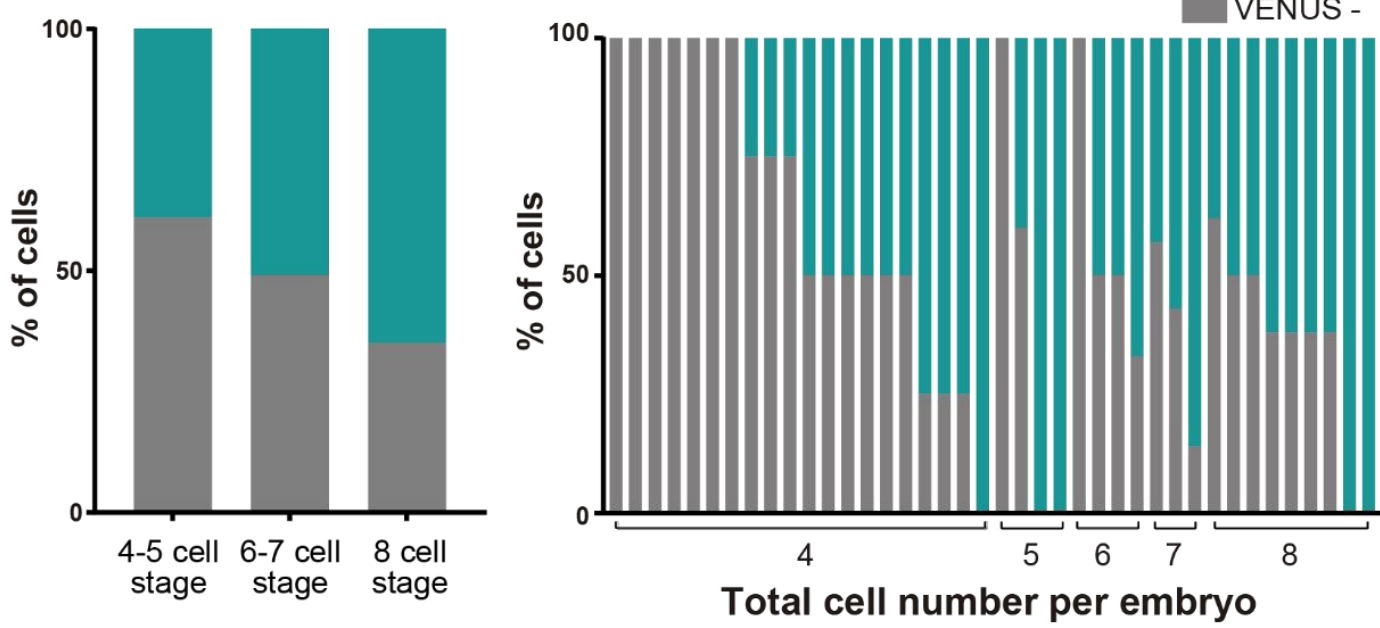

Figure 17. The Notch pathway is active from the 4-cell embryo. (A) Maximal projections of confocal images of CBF1-VENUS reporter line in 4-cell, 6-cell, 8-cell and compacted morula stages. Immunostaining for phospho-ERM (bottom row) confirms acquisition of apical polarity in compacted morulae. Nuclei were stained with DAPI. Scale bar, $20 \mu \mathrm{m}$. (B) Mean percentage of VENUS positive cells per embryo at different stages (4-5 cell embryos, $n=24 ; 6-7$ cell embryos, $n=7 ; 8$-cell embryos, $n=9$ ). (C) Percentage of VENUS positive cells in single embryos from 4- to 8-cell stages (indicated on the $x$-axis). 
A

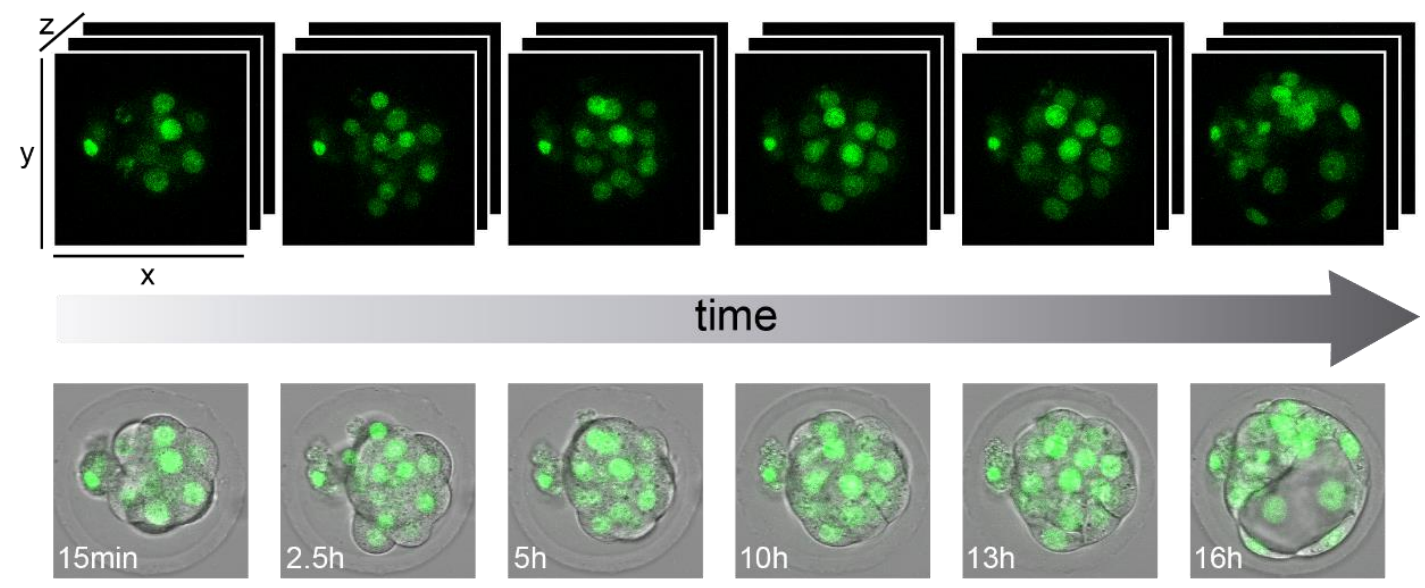

B

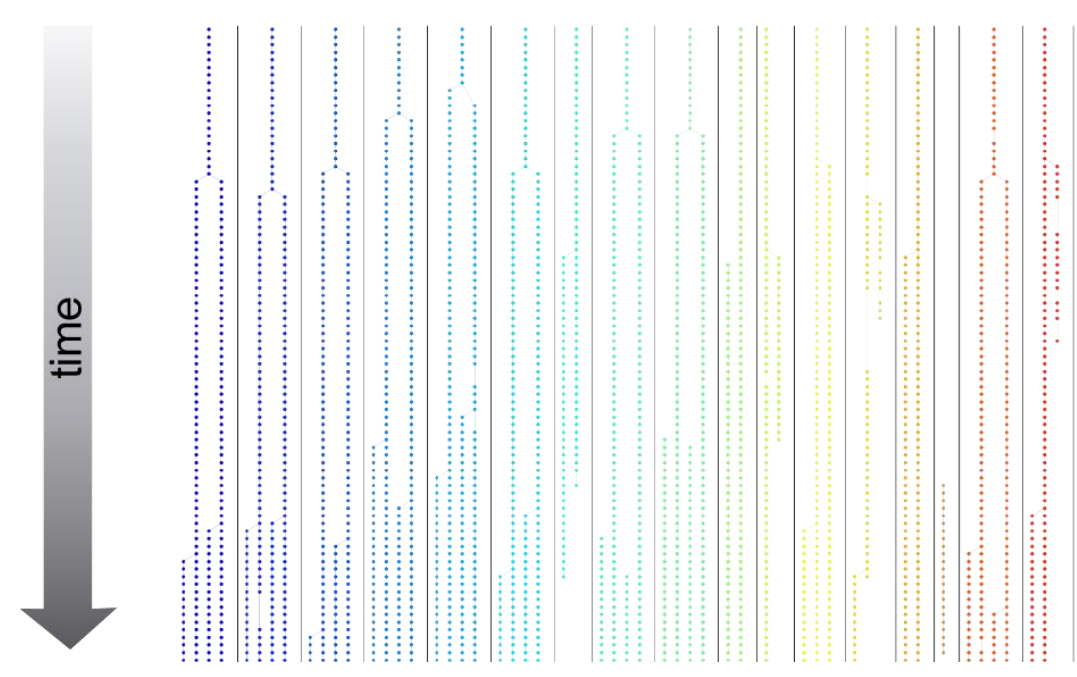

Figure 18. Live imaging of morula to blastocyst transition in CBF1-VENUS embryos. (A) Schematic diagram showing 3D + time image data acquisition of CBF1VENUS embryos. Maximal projections of confocal images of VENUS (upper row) or VENUS + brightfield (bottom row) are shown. Time since the onset of time lapse is indicated. (B) Cell tracking and family tree (each family in a different colour) after live imaging (see Movie 1).

To analyse the data collected after live imaging, we developed VTONI, a Matlab based tool that allows to visualise and monitor the behaviour of each individual cell and its progeny within the embryo. With this tool, we were able to reconstruct each time point and assign an initial position (inner or outer) to each blastomere as well as its final location in the TE/OUT or the ICM/IN positions (Figure 19, Movie 2). 

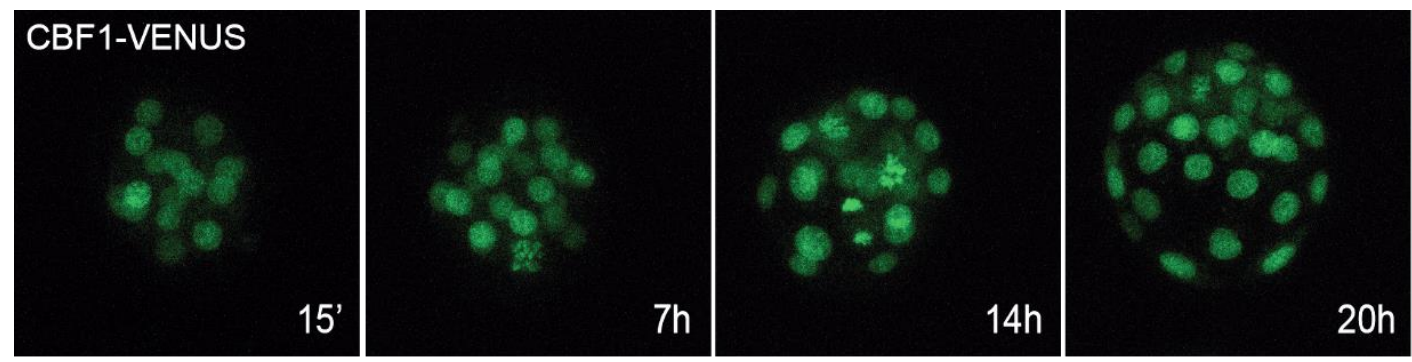

3D-Reconstruction
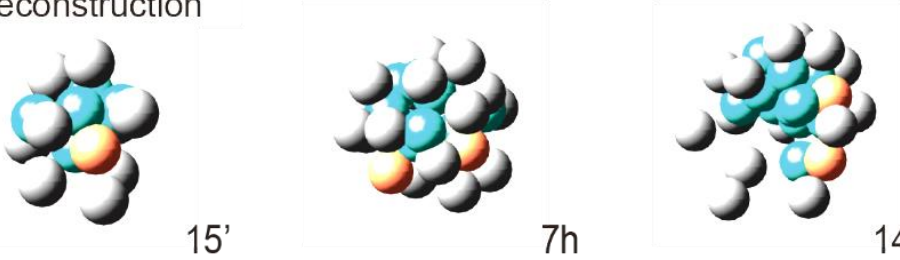

$14 \mathrm{~h}$

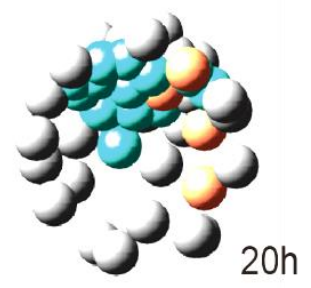

Figure 19. 3D visualization of embryos after time lapse imaging. Maximal projections (top row) and 3D reconstructions (bottom row) of four time-points during live imaging of embryos from the CBF1-VENUS reporter line. A selected cell and its progeny are highlighted in orange. Blue blastomeres indicate inner position and grey blastomeres indicate outer position. Time since the onset of time lapse is indicated.

By means of the 3D reconstruction and the lineage trees, we classified families according to the position of the cells at the first and final time points. This allowed us to divide the families in four groups: "IN-ICM" (cells that began in an inner position and their descendants remained in an inner position), "IN-TE+ICM" (cells that began in an inner position and at least one of their descendants ended up in an inner position but other/s in an outer position), "OUT-TE" (cells that began in an outer position and their descendants remained in an outer position), and "OUT-TE+ICM" (cells that began in an outer position and at least one of their descendants ended up in an outer position but other/s ended up in an inner position).

Confirming previous findings (Anani et al., 2014; McDole et al., 2011; Posfai et al., 2017; Toyooka et al., 2016; Watanabe et al., 2014), although most of the cells of the blastocyst retained the position of their predecessor cell in the compacted morula, a small percentage changed their location (Figure 20A). We next quantified intensity levels of the VENUS reporter in all cells within families, and determined if it correlated with their position during the time lapse. Notch activity levels were variable among families and 
embryos, but when we analysed the mean intensity for each group, we found that VENUS levels were significantly lower in the families that were always inside as compared to the families that were always outside (Figure 20B). Interestingly, this difference was already established when we measured the initial intensity in the first time point (Figure 20C). In the families whose cells end up in both inner and outer position, VENUS levels were intermediate (Figure 20B-C). When we analysed families individually, we detected higher and increasing levels in OUT-TE families while IN-ICM families generally showed lower and decreasing levels. The intensity levels in families that contributed to both TE and ICM did not follow a clear pattern (Figure 20D-F).

Therefore, the analysis of the CBF1-VENUS line showed that the reporter is active before the first lineage decision is taken, and that differences in the levels of pathway activation in inner or outer cells of the compacted morula correlate with the final position of their descendants in the blastocyst. 
A

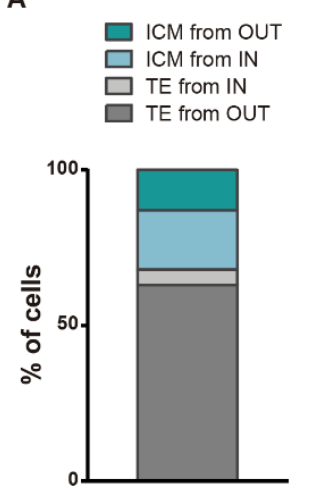

D

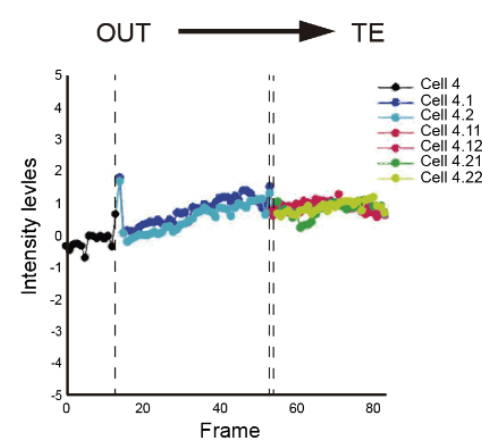

B

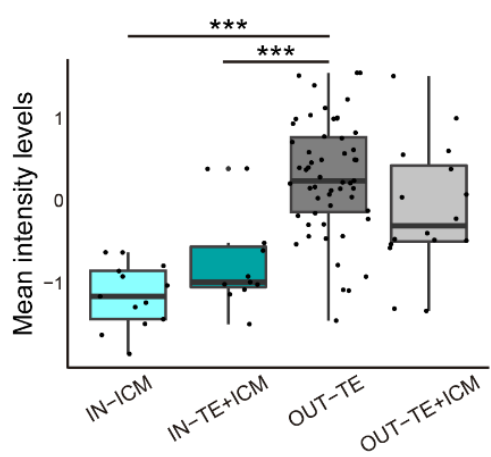

$\mathbf{E}$
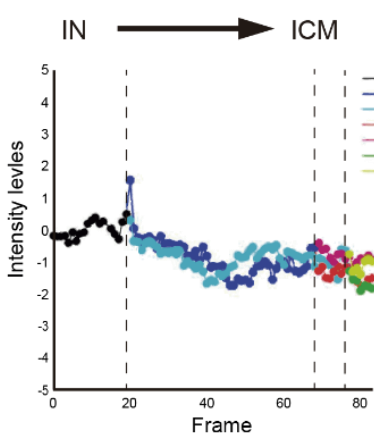

C

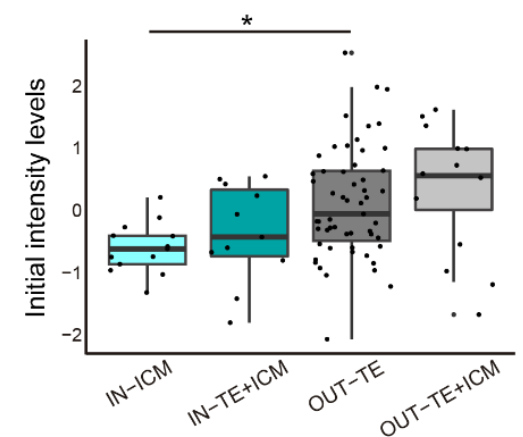

$\mathbf{F}$

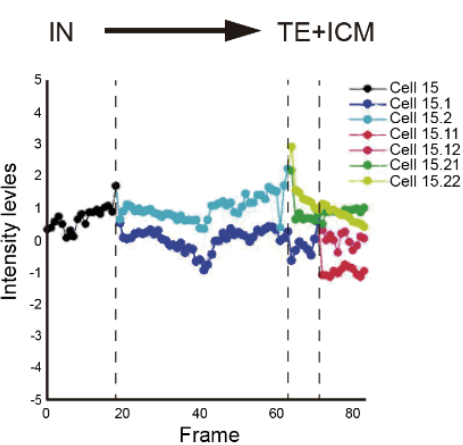

Figure 20. CBF1-VENUS dynamics in the morula to blastocyst transition. (A) Percentage of cells from the ICM or from the TE according to the position (IN/OUT) of their progenitor cell in the first frame of the time lapse $(n=7)$. (B) Mean intensity levels of VENUS in all the families of the live imaged embryos $(n=7)$ according to the position of a cell and their progeny in the first and the final time frame. (C) Initial intensity levels of VENUS in all the families of the live imaged embryos according to the position of a cell and their progeny in the first and the last time frame. $n=13$ families for IN-ICM, n=11 families for IN-TE+ICM, n=55 families for OUT TE, $n=16$ families for OUT-TE+ICM. ${ }^{* * *} p<0.001,{ }^{*} p<0.05$ by ANOVA with Bonferroni post-test. (D-F) Representative examples of VENUS intensity levels of cells from families with different outcomes relating to their position in the first and final frame of the time lapse movies.

\section{Different Notch levels determine cell position in the morula and in the blastocyst}

Previous results have shown that forced activation of Notch activity does not impede blastocyst formation but leads to a preferential allocation of cells to the outer trophectoderm (Rayon et al., 2014; Souilhol et al., 2015). However, the onset of this effect had not been tested nor whether blocking Notch would have an effect in cell allocation. 
To address these questions, we used a genetic mosaic line (iChr-Notch-Mosaic) that allowed us to generate cells with different Notch activity levels and confront them within the same embryo (Pontes-Quero et al., 2017). The construct consists of three different cassettes preceded by specific loxP sites. The first cassette is a H2B-CHERRY fluorescent protein that, upon recombination, generates red wildtype cells. The second cassette contains a dominant-negative version of Mastermind-like 1 (DN-MAML1), a transcriptional coactivator of the Notch pathway, linked to a H2B-eGFP by a cleavable 2A peptide, whose expression leads to the loss of function (LOF) of the pathway. The third one is a gain of function (GOF) cassette that expresses a constitutively active NICD linked to an $\mathrm{HA}-\mathrm{H} 2 \mathrm{~B}-\mathrm{Cerulean}$. The specific loxP sites are mutually exclusive, so in any unique cell there will be only one possible outcome as the result of Cre-mediated recombination. We used a Polr2a $a^{\text {CreERT2 }}$ driver which is ubiquitously expressed and inducible by tamoxifen (Guerra et al., 2003). We induced recombination by adding 4OH-Tx (4-hydroxytamoxifen) from the 2- to the 4-cell stage, aiming to achieve a situation where cells expressing each cassette derive from a single recombined blastomere, and we evaluated recombination in the late morula ( $<32$ cells) or in the blastocyst (Figure 21A). We performed immunofluorescent assays with three antibodies to distinguish the three cassettes. The wildtype cassette was detected by an anti-RFP antibody, the LOF by an anti-GFP antibody, and the GOF an anti-HA antibody. However, GOF cells were triple positive because of cross-reactivity between antibodies and the HA-H2B-Cerulean protein (Figure 21B). 
A

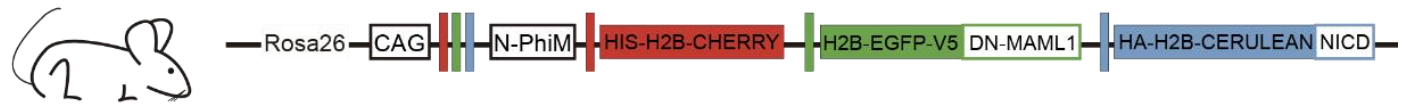
iChr-Notch-Mosaic

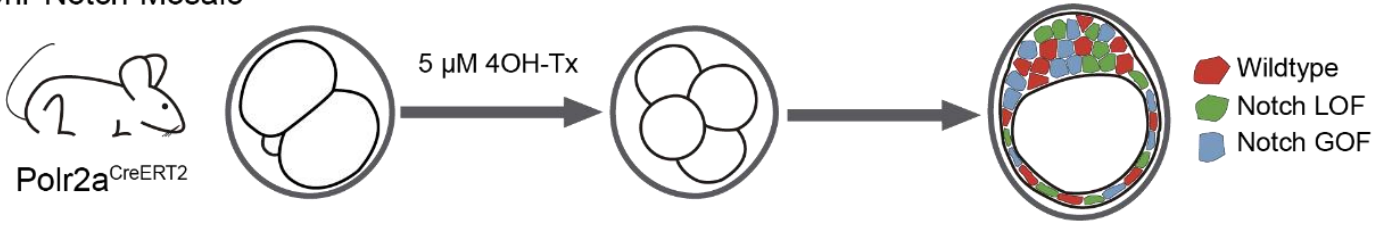

B

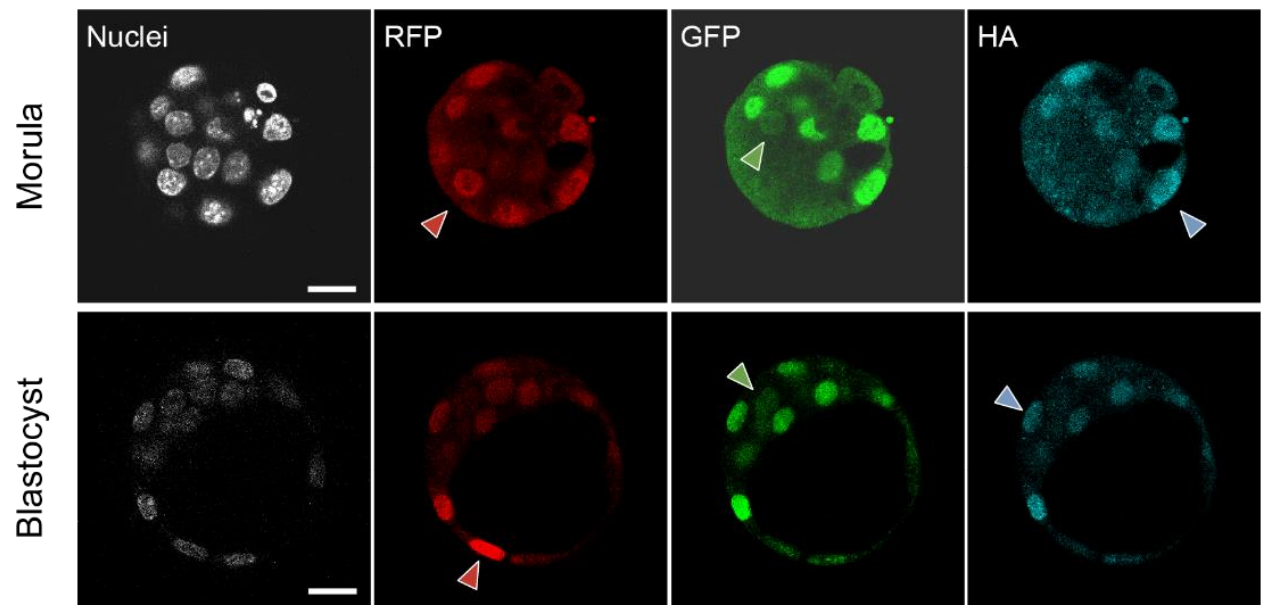

Figure 21. Confronting different Notch activity levels within the embryo. (A) Schematic diagram of the experimental strategy, where iChr-Notch-Mosaic mice were crossed with Polr2aCreERT2 driver. Embryos were collected and treated with $4 \mathrm{OH}$ Tamoxifen from 2- to 4-cell stage to induce recombination. At morula and blastocyst stage, embryos were fixed and immunostained. (B) Optical section of confocal images after immunostaining for RFP, GFP and HA. Arrowheads indicate examples of cells recombined for the wildtype cassette (red), the Notch loss of function cassette (LOF, green) or the Notch gain of function cassette (GOF, blue). Nuclei were stained with DAPI. Scale bars, $20 \mu \mathrm{m}$.

We selected embryos in which all three recombination events had occurred and analysed the percentage of cells expressing the control, LOF or GOF cassette. Although the probabilities of recombination are higher when the loxP sites are closer to one another (the wildtype recombination event in this case), we observed that most of the cells were Notch GOF while only a small proportion were Notch LOF both in the morulae and blastocysts analysed (Figure 22A-B). Quantifying all of the embryos, we found that $58 \%$ of the cells were Notch GOF, $32 \%$ were wildtype cells and only a $10 \%$ were Notch LOF cells, what suggests that Notch activity could affect cell proliferation in the embryo (Figure 22C). Next, we determined the proportion of cells from each population that 
were in inner or outer positions in order to see if there was a correlation with the levels of Notch as we could expect after the live imaging analysis in CBF1-VENUS embryos. Approximately $60 \%$ of wildtype cells were located at outer positions in both morula and blastocyst stage. Interestingly, this proportion was not maintained when Notch activity levels were altered. Notch LOF cells were enriched at inner positions of the morula or in the ICM of the blastocyst, while Notch GOF cells tended to occupy outer positions in both cases (Figure 22D-E). These experiments show how manipulating levels of Notch pathway activity as early as the 4-cell stage instructs cells to adopt an inner or outer position at later stages.

A

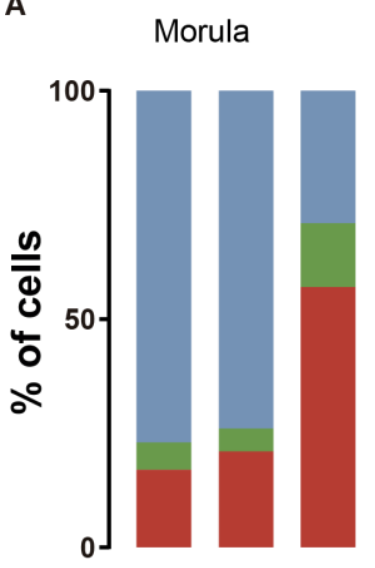

C

Wildtype

Notch LOF

Notch GOF

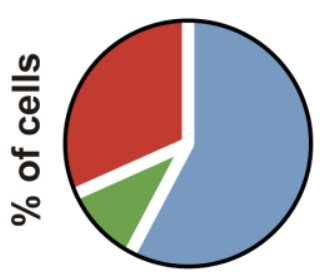

B

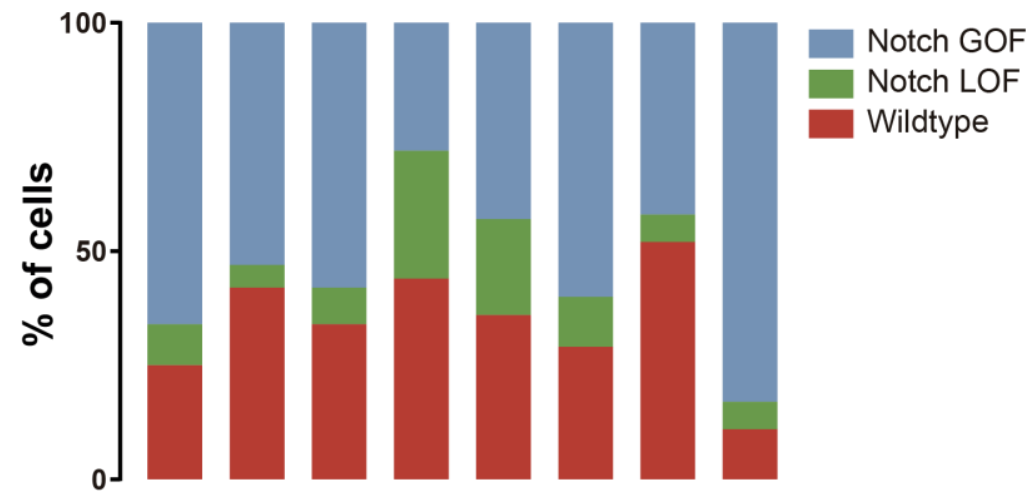

D

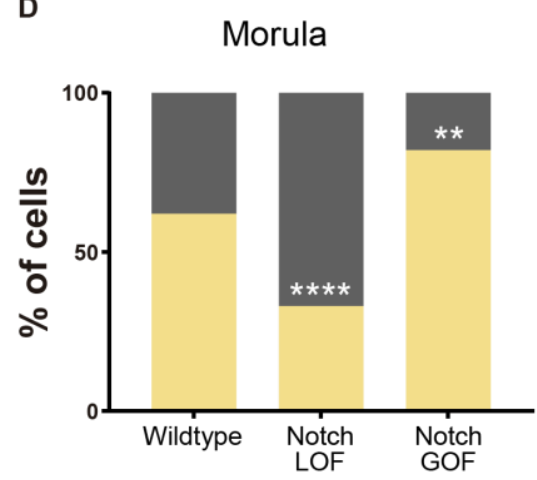

E
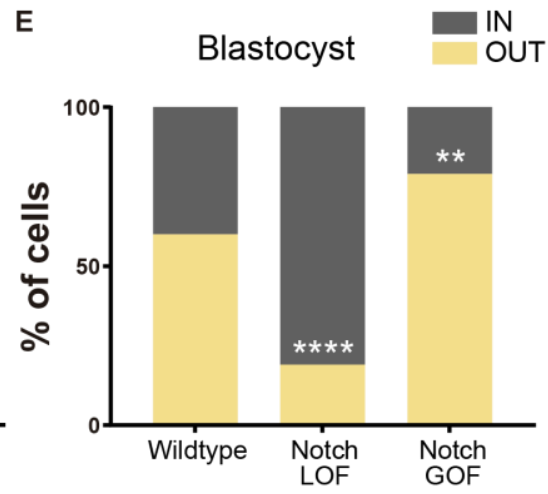

Figure 22. Differences in Notch activity drive cell fate in the preimplantation embryo. (A-B) Percentage of cells recombined for each cassette (wildtype, red; LOF, green; GOF, blue) in individual morulae (A) or blastocysts (B) from the iChr-NotchMosaic mouse line. (C) Percentage of cells recombined for each cassette $(n=11)$. (D-E) Percentage of cells for each cassette that are in an inner (grey) or outer (yellow) position at the morula ( $D$; Wildtype, $n=21$; LOF, $n=6$; GOF, $n=44$ ) or blastocyst stage (E; Wildtype, $n=75 ;$ LOF, $n=26 ;$ GOF, $n=131$ ). ${ }^{* *} p<0.01$, ${ }^{* \star \star *} p<0.0001$ by Fisher's exact test. 


\section{Lack of Rbpj disrupts the triggering of differentiation programs in the morula}

Results described so far show that the Notch pathway plays a role in mouse development and in regulating $C d \times 2$ expression, earlier and non-redundant with that of the Hippo pathway, and in determining the location of cells to inner or outer positions. To gain further insight into how Notch is acting during preimplantation development, we performed RNA-sequencing (RNA-seq) in control and $\mathrm{Rbpj}^{--}$single morulae, obtained from the same litter to reduce variability. Hierarchical clustering separated the control group (wildtype and heterozygotes) from homozygous Rbpjmutant morulae (Figure 23).

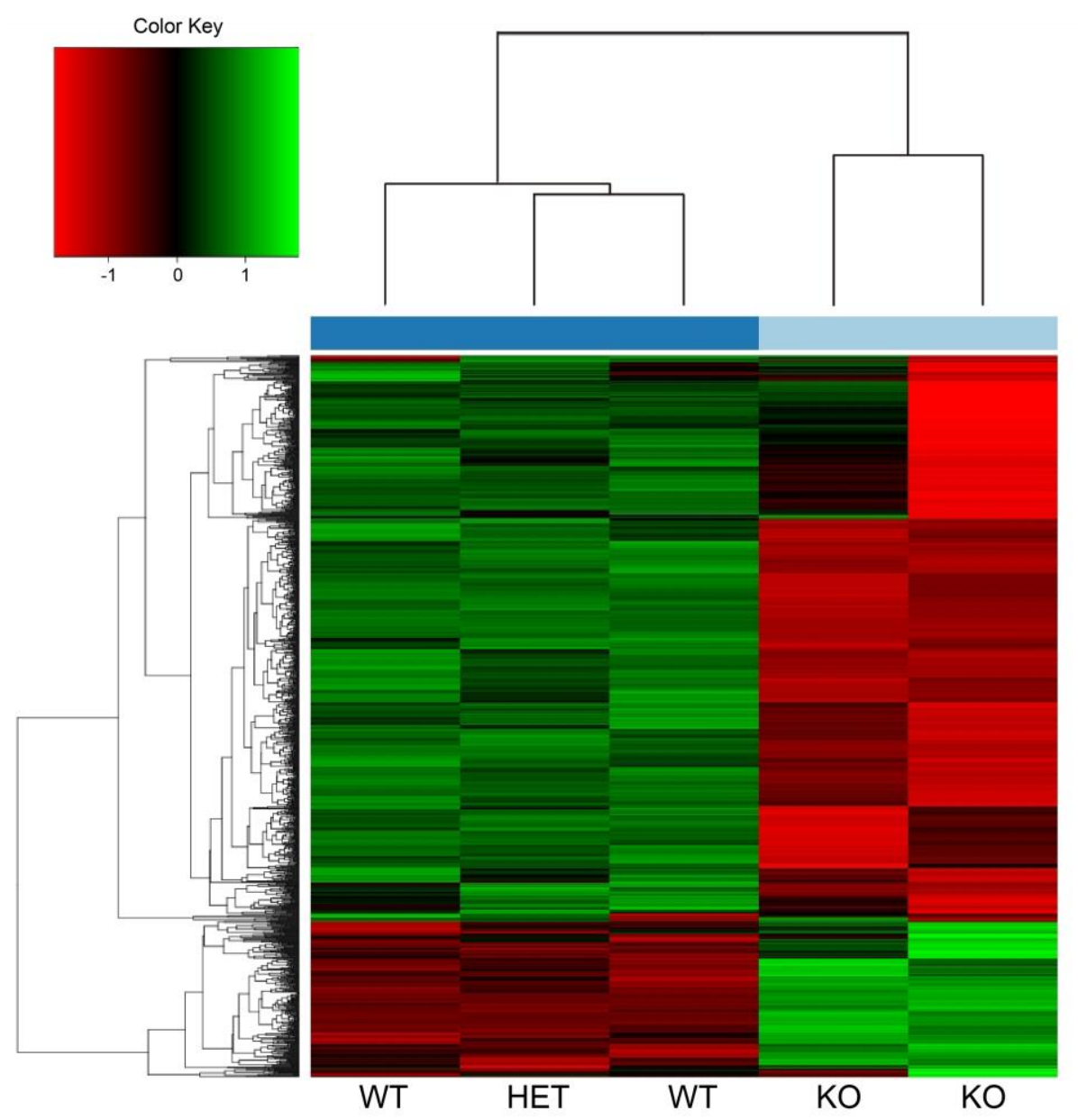

Figure 23. Transcriptome profiling of $\boldsymbol{R} b$ pj mutant morulae. Hierarchical clustering separates the control group ( 2 wildtype, WT; and 1 heterozygous, HET, embryos) from Rbpj mutant morulae (KO). Colour code from red to green indicates lower or higher levels of expression for each differentially expressed gene (adjusted $p$-value $<0.05$ ). 
1273 genes were differentially expressed (Appendix 1), 79\% of which were downregulated, suggesting that $R b p j$ is mainly activating gene expression in the morula. Among the downregulated genes we found $C d \times 2$ and other TE associated genes such as Gata2, Gata3 or Fgfr2 (Haffner-Krausz et al., 1999; Home et al., 2009, 2017; Ralston et al., 2010; Strumpf et al., 2005); genes related with the Hippo pathway (Tead4, Nf2, Lats2) and, interestingly, also genes related with the embryonic pluripotency network such as SallI, Sall4, Tbx3 or Sox21 (Figure 24A-B) (Goolam et al., 2016; Han et al., 2010; Karantzali et al., 2011; Niwa et al., 2009; Yang et al., 2010). Among the upregulated genes, we found Dppa3 (Stella) and Prdm14, which have been characterised as naïve pluripotency markers (Figure 24A-B) (Hayashi et al., 2008; Yamaji et al., 2013). Moreover, a large set of chromatin modifiers were differentially expressed (Figure 24C). Important chromatin dynamics have been reported during preimplantation development (Burton and TorresPadilla, 2014), which could fit with a broad mis-regulation of transcription in the mutant embryos. Remarkably, some of the downregulated modifiers like Dnmt3bor Kdm6a have been shown to be enriched in the trophectoderm conversely to Prdm14 (Burton et al., 2013). Overall, the transcriptome profiling suggests that embryos lacking Rbpj do not properly trigger trophectoderm differentiation programs, although they also show defects in pluripotency related genes. 
A

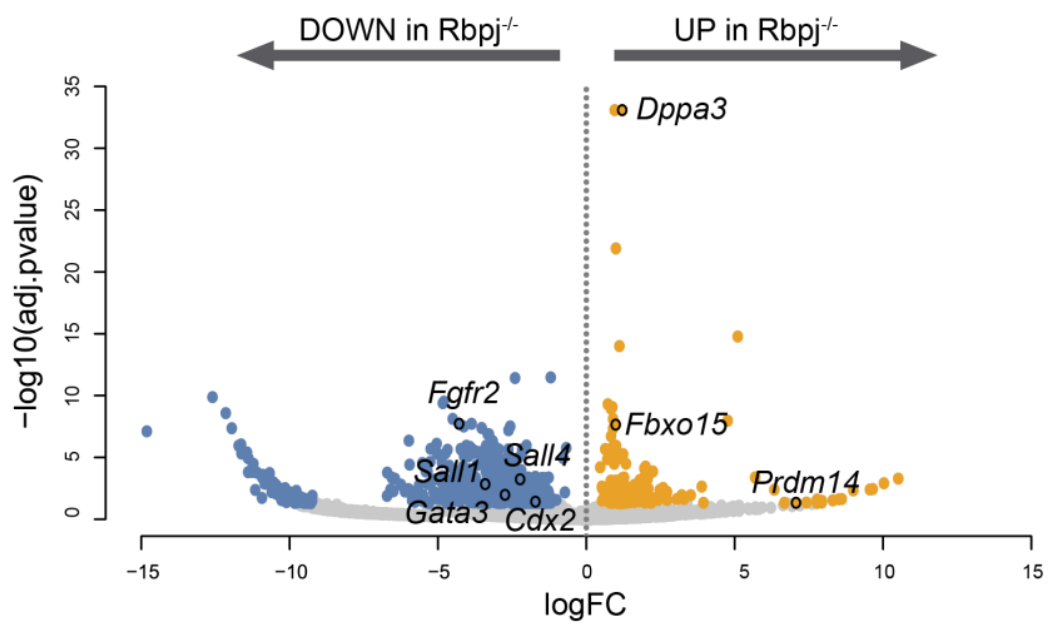

B

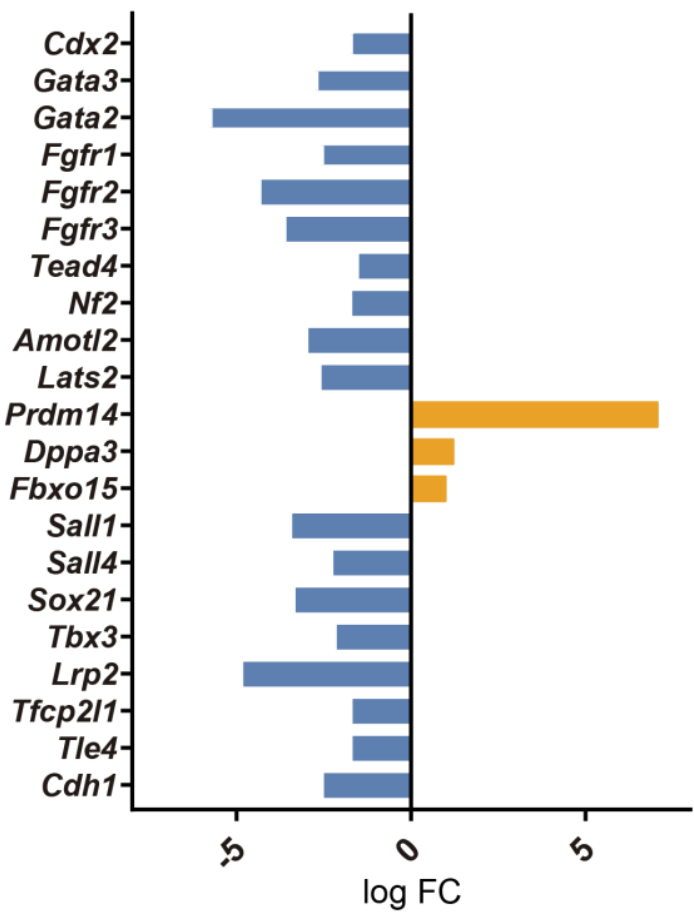

C

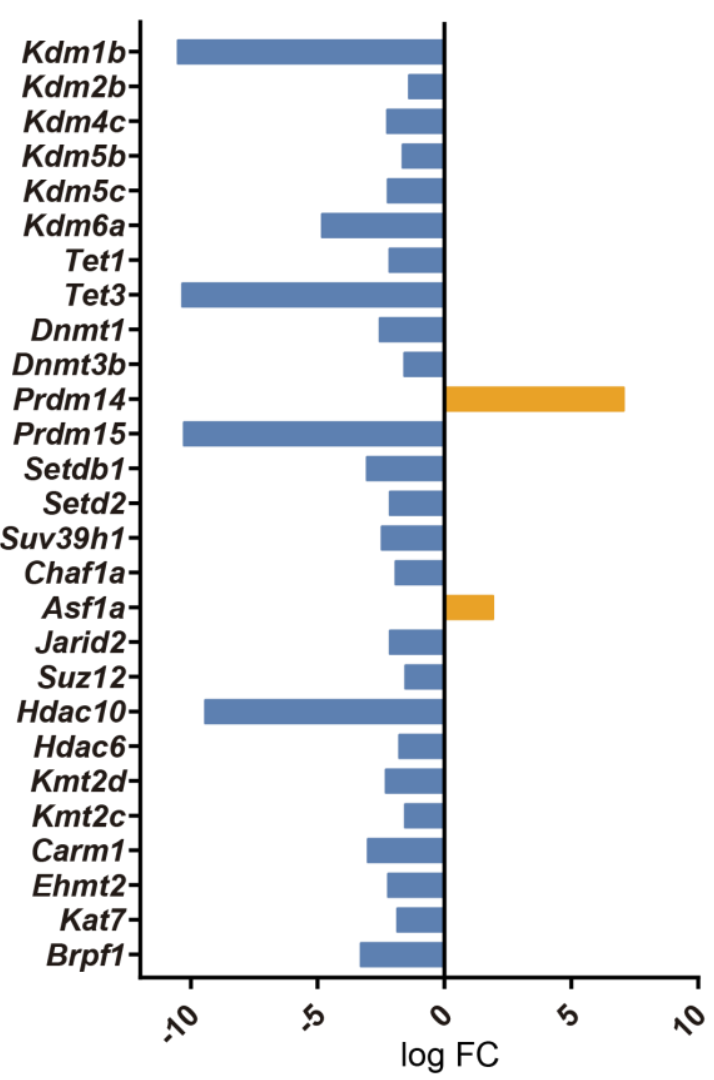

Figure 24. Differentially expressed genes between control and Rbpj mutant morulae. (A) Volcano plot of differentially expressed genes between control and $R b p j$ ${ }^{\prime}$ single morulae. In blue, genes downregulated in $R b p j^{\prime-~ e m b r y o s ~(~} \mathrm{p}$-adj $<0.05$ and $\log \mathrm{FC}<-1)$; in orange, genes upregulated in $R b p j^{--}$embryos $(\mathrm{p}$-adj $<0.05$ and logFC $>$ 1). Representative genes are indicated. (B-C) log FC of selected differentially expressed genes between control and $R b p j^{\gamma-}$ embryos related with lineage programs (B) or chromatin modifiers (C). 


\section{Notch regulates the transcriptional repressor coding genes Tle4 and $T b \times 3$ in the early embryo}

To identify putative direct targets of Notch signalling at this stage, we searched for consensus RBPJ binding sites in the vicinity of differentially expressed genes. We established an arbitrary window of $10 \mathrm{~Kb}$ surrounding each gene to perform the analysis and found RBPJ binding motifs in 921 genes. To further restrict this list, we examined how many of these putative binding sites were located in open chromatin regions, a hallmark for active regulatory elements. To do so, we took advantage of ATAC-seq profiles from published datasets of 8-cell mouse embryos (Wu et al., 2016), and reduced our list to 186 candidate genes (Figure 25, Appendix 2). Among these genes was $C d x 2$, where the predicted RBPJ binding site and ATAC-seq open chromatin signature mapped to the TEE enhancer we have previously characterised (Rayon et al., 2014), thus validating our approach.

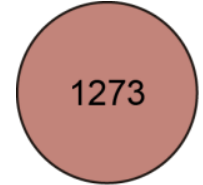

DEG

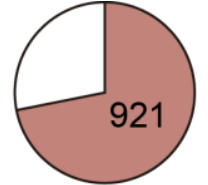

DEG

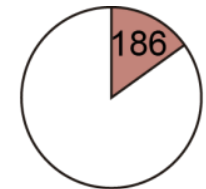

DEG

RBPJ motif (10 Kb window) RBPJ motif (10 Kb window) ATAC-seq (8-cell embryos)

Figure 25. Analysis of differentially expressed genes in Rbpj mutants versus control morulae. Number of differentially expressed genes (DEG) between wildtype and $R b p j^{\%-}$ morulae (left), those that have a RBPJ motif in a $10 \mathrm{~Kb}$ window surrounding the gene (middle), and those in which this site is included in an open chromatin ATACseq peak in 8-cell embryos (Wu et al., 2016) (right).

From that list, we selected two genes as putative Notch targets that were downregulated in Rbpj mutant morulae and had been previously associated with exit from pluripotency in mouse ES cells. These are those coding for the Groucho-family transcriptional repressor TLE4 (Laing et al., 2015) and the T-box family transcription factor TBX3 (Russell et al., 2015; Waghray et al., 2015). Both genes are heterogeneously expressed in ES cells 
and repress naïve pluripotency genes. We hypothesized that Tle4 and Tbx3 could be direct targets of Notch signalling and that their downregulation could in part explain the blockade in differentiation that we observed in the RNA-seq analysis. Treatment of wildtype embryos with the Notch pathway inhibitor RO4929097 from 2-cell to morula stage confirmed a significant reduction in both Tbx3 and Tle4 levels (Figure 26).

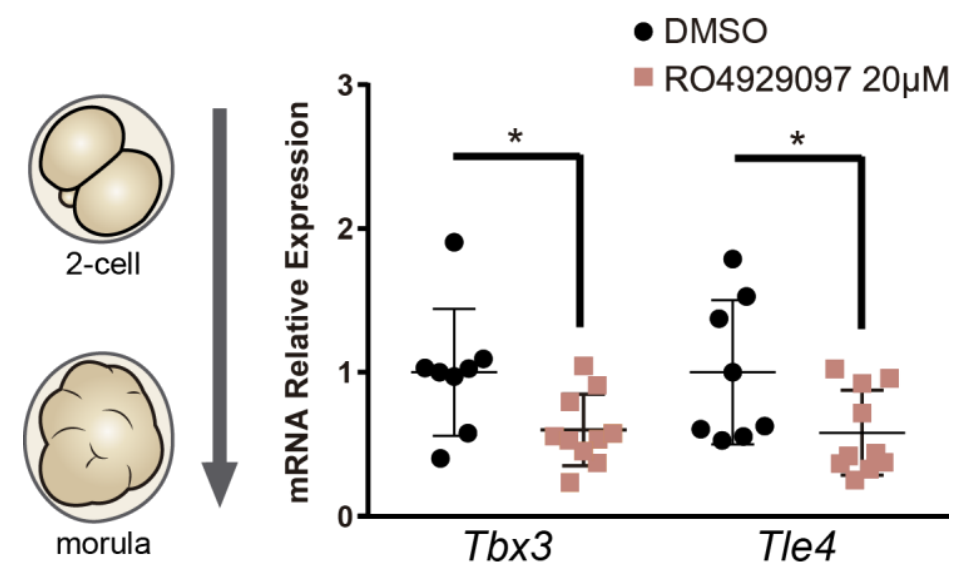

Figure 26. Notch signalling inhibition leads to reduction in Tbx3 and Tle4 expression. Tbx3 and Tle 4 relative expression in pools of 25 embryos after treatment with RO4929097 to block Notch from 2-cell to morula stage. Pools of embryos treated with DMSO were used as controls. Data are means $\pm s . d .{ }^{*} p<0.05$ by Student's $t$ test

The RBPJ binding motif search within ATAC-seq peaks identified two potential candidate regulatory regions in the vicinity of Tle4 and Tbx3. They are located $1.3 \mathrm{~Kb}$ upstream of Tle4 (Tle4-up) and in the seventh intron of $T b \times 3$ (Tbx3-i7) respectively. We decided to test the potential regulatory function of these non-coding regions and the involvement of Notch signalling in their activity.

\subsection{Notch-mediated regulation of Tle4 in the preimplantation embryo}

Screening of non-coding DNA sequences by transient transgenic assays has long been used to identify functional enhancers in vivo (Banerji et al., 1981). We tested the $700 \mathrm{bp}$ sequence upstream of Tle4 (Figure 27A) and proved that the Tle4-up region could act as transcriptional enhancer driving $\mathrm{H} 2 \mathrm{~B}-\mathrm{mRFP}$ reporter expression in the morula (32\% of 
positive embryos) (Figure 27B-C). To investigate if Notch was directly involved in this regulation, we mutated the RBPJ motif included in the Tle4-up sequence and observed that the activity of the Tle4-up mut ${ }^{\text {RBPJ }}$ fragment was significantly diminished (from $32 \%$ to $13 \%$ positive embryos) (Figure 27B-C).

A

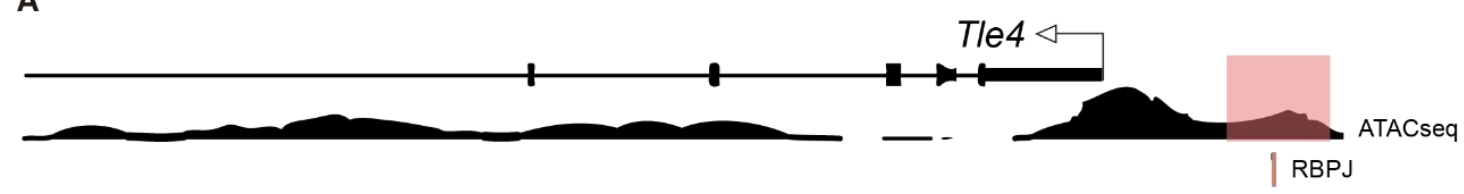

B
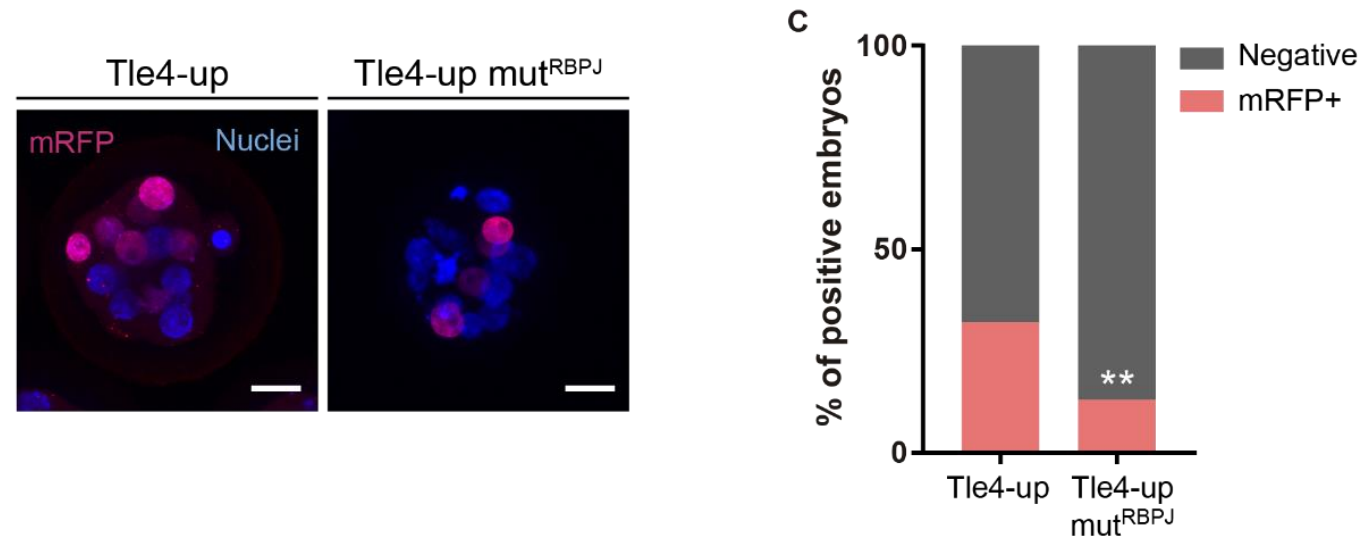

Figure 27. An RBPJ consensus binding site is necessary for full activity of the Tle4up enhancer. (A) Genomic landscape of the region upstream Tle4 indicating the location of the RBPJ motif and the ATAC-seq track. (B) Maximal projection of confocal images after RFP immunostaining of representative transgenic embryos for the region highlighted in pink in (A) (left) or the mutated version for the RBPJ site (right). Nuclei were stained with DAPI. Scale bar, $20 \mu \mathrm{m}$. (C) Percentage of positive embryos in the transient transgenic assay of Tle4-up region $(n=137)$ or the mutated version $(n=169)$. ** $p<0.01$ by Fisher's exact test.

Finally, to examine whether the Tle4-up enhancer was necessary for the endogenous expression of Tle4, we deleted a region within the enhancer that contained the RBPJ motif by CRISPR/Cas9 mediated genome editing (Ran et al., 2013), and analysed gene expression by RT-qPCR on individually edited E2.5 embryos. We observed a significant decrease in Tle4 expression in edited morulae (deleted, $\mathrm{n}=10$ ) as compared to injected embryos that were partially (mosaic, $n=9$ ) or not edited (wildtype, $n=14$ ) (Figure 28). 

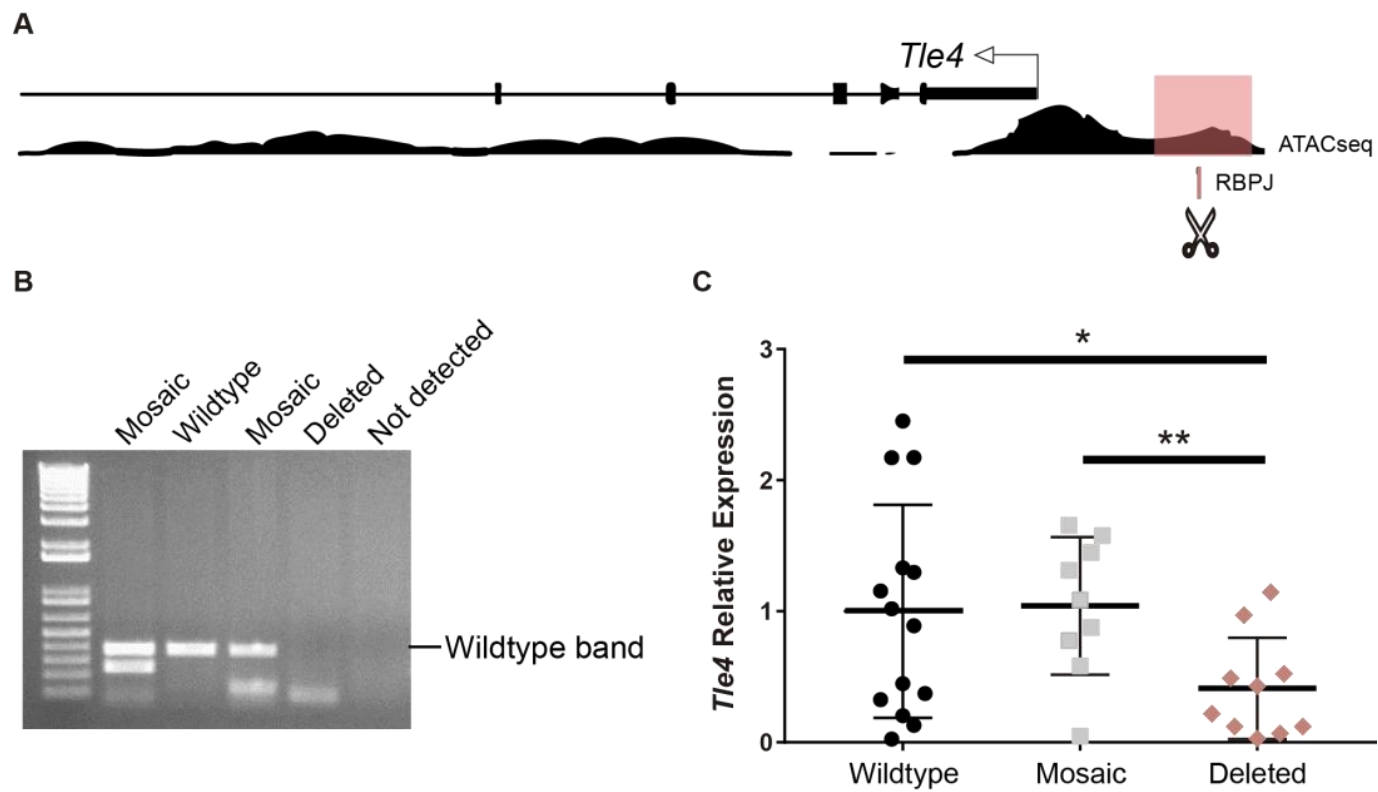

Figure 28. Tle4 is a direct target of RBPJ. (A) Genomic landscape of the region upstream Tle4 indicating the location of the RBPJ motif to be deleted (represented with scissors) and the ATAC-seq track. (B) Representative gel of PCR-genotyping of individual E2.5 embryos showing wildtype, mosaic, deleted and not detected samples. (C) Tle4 relative expression in single embryos (wildtype, $n=14$; mosaic, $n=9$; deleted, $\mathrm{n}=10$ ) after CRISPR/Cas9 deletion of the region containing the RBPJ motif. Data are means \pm s.d. ${ }^{*} p<0.05$ by Student's t test in $(C)$ and $(G) .{ }^{* *} p<0.01$ by Student's test

\subsection{Deciphering the regulation of $T b \times 3$ in the preimplantation embryo}

To study the potential enhancer activity of the non-coding sequence that has an RBPJ binding motif inside an ATAC-seq peak in the Tbx3 locus, we followed the same strategy. In this case, the candidate region is located in the seventh intron of $T b \times 3$ (Tbx3-i7) (Figure 29A). By means of transient transgenic assay, we showed that this $600 \mathrm{pb}$ sequence presented enhancer activity driving H2B-mRFP reporter expression in the E2.5 embryo (56\% of positive embryos). However, when we mutated the RBPJ motif included in this region, the activity of the $\mathrm{Tb} \times 3-i 7$ mut ${ }^{\mathrm{RPP}}$ fragment was not affected (60\% of positive embryos) (Figure 29B-C). We next deleted a region included in the Tbx3-i7 enhancer containing the RBPJ binding motif by CRISPR/Cas9 mediated genome editing. RT-qPCR analysis on individual edited embryos revealed that $T b \times 3$ expression did not change when the RBPJ motif was deleted (Figure 29D-E). 
Therefore, these assays provide evidence that these non-coding genomic regions act as cis-regulatory elements and, in the case of Tle4, are directly regulated by RBPJ and necessary for correct expression. However, the regulatory element from $T b \times 3$ does not depend solely of RBPJ for its activity.

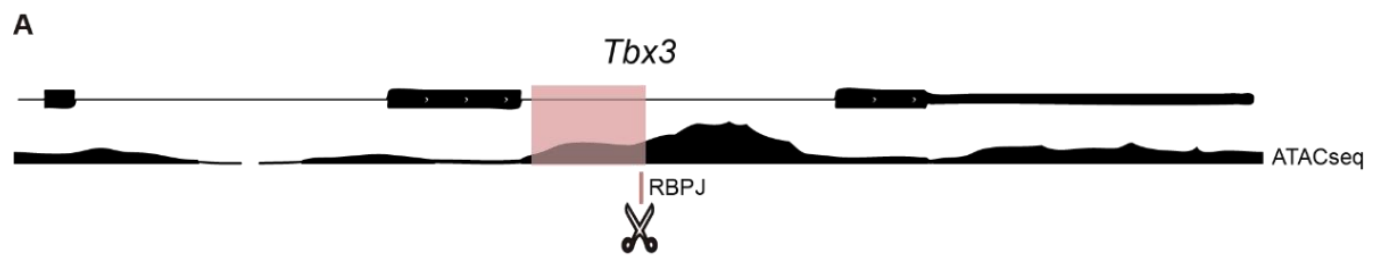

B

C
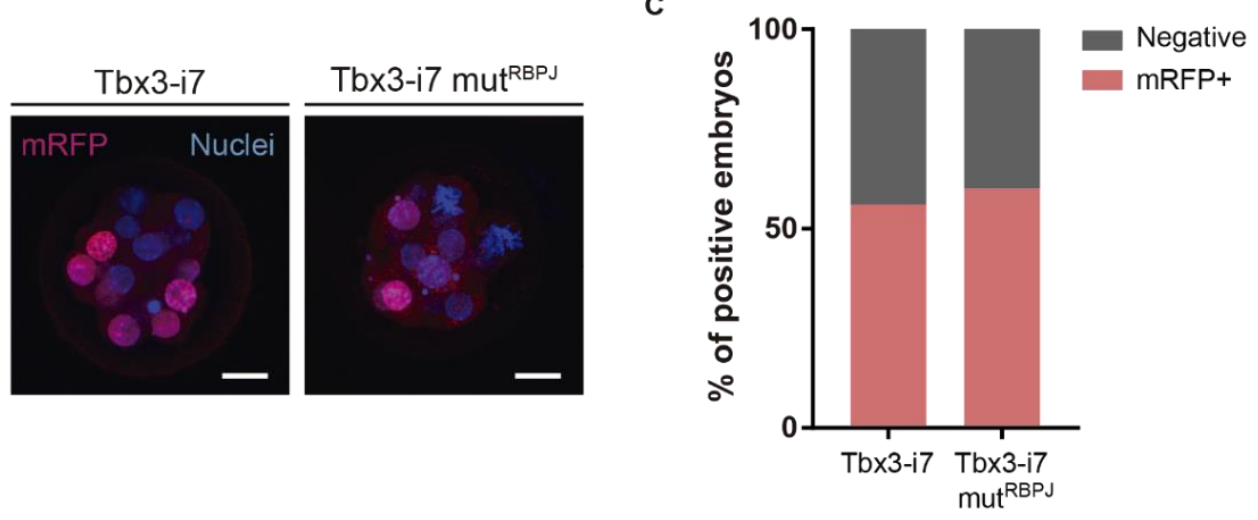

D

$E$
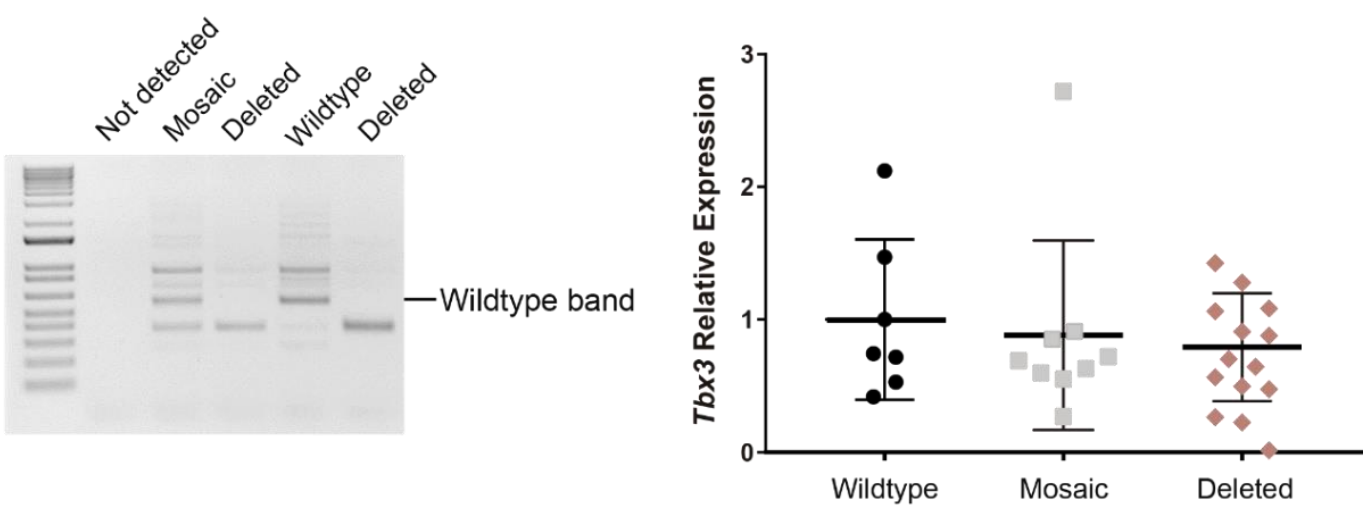

Figure 29. Testing the regulation of $T b \times 3$ in the morula. (A) Genomic landscape of the region surrounding the seventh intron of $T b \times 3$ indicating the RBPJ motif to be deleted (represented with scissors) and the ATAC-seq track. (B) Maximal projection of confocal images after RFP immunostaining of representative transgenic embryos for the region highlighted in pink in (A) (left) or the mutated version for the RBPJ site (right). Nuclei were stained with DAPI. Scale bars, $20 \mu \mathrm{m}$. (C) Percentage of positive embryos in the transient transgenic assay of Tbx3-i7 region $(n=75)$ or the mutated version ( $n=80$ ). (D) Representative gel of PCR-genotyping of individual E2.5 embryos showing wildtype, mosaic, deleted and not detected samples. (E) Tbx3 relative expression in single embryos (wildtype, $n=7$; mosaic, $n=9$; deleted, $n=10$ ) after CRISPR/Cas9 deletion of the region containing the RBPJ motif. Data are means \pm s.d. 


\section{Notch coordinates the balance between naïve pluripotency and triggering of differentiation in ES cells}

The transcriptomic profiling carried out in Rbpj mutant embryos identified genes related with naïve pluripotency among the upregulated genes. Naïve pluripotency corresponds to a state in which cells are refractory to differentiation, in contrast to cells that are in a primed pluripotency state (Kalkan and Smith, 2014). These pluripotent states, as well as the transition between them, have been extensively studied in ES cells and Epi-Like cells (EpiLCs), in vitro counterparts of the epiblast of the preimplantation embryo and the epiblast of the postimplantation pre-gastrulating embryo respectively (Hackett and Surani, 2014).

\subsection{Naïve pluripotency genes in the preimplantation embryo}

There are a number of naïve pluripotency markers that are also expressed in the preimplantation embryo before the specification of the first lineage programs. Prdm14 is initially expressed at the 2- and 4-cell stage, switched off in the morula and reexpressed in the ICM of the blastocyst (Burton et al., 2013). Analysis of published singecell RNA-seq data (Goolam et al., 2016) confirmed that Prdm14 decreased drastically from the 4-cell to 8-cell stage, and expression of Dppa3 also decreased from the 2-cell to the 4-cell stage (Figure 30). In contrast, Tle4 and Tbx3 expression augmented from the 4-cell to 8-cell stage (Figure $\mathbf{3 0}$ ).

Our data from Rbpj mutant morulae suggests that embryos do not properly switch off Prdm14 nor Dppa3, since their expression is upregulated as compared to control embryos. Blocking Notch signalling with RO4929097 from the 2-cell to 4-cell stage confirmed the effect on Prdm14, whose levels were significantly increased after the treatment (Figure 31). However, Dppa3 expression did not change suggesting that the effect is stronger on Prdm14. 

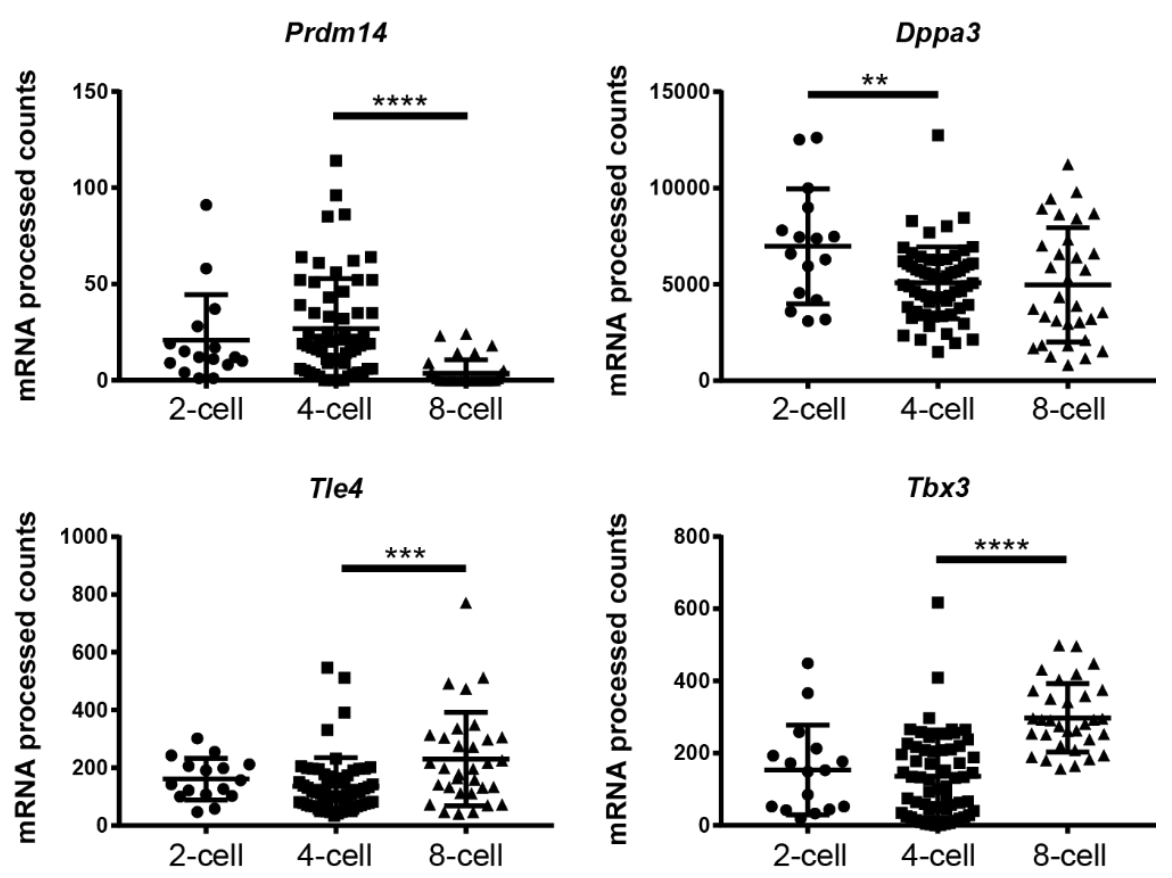

Figure 30. Naïve pluripotency markers in the preimplantation embryo. Expression of Pdrm14, Dppa3, Tle4 and Tbx3 in 2-cell, 4-cell and 8-cell stage single-cell RNA-seq data from Goolam et al. (Goolam et al., 2016). Data are means \pm s.d. ** $p<0.01$, *** $p<0.001,{ }^{* \star * *} p<0.0001$ by ANOVA with Fisher post-test
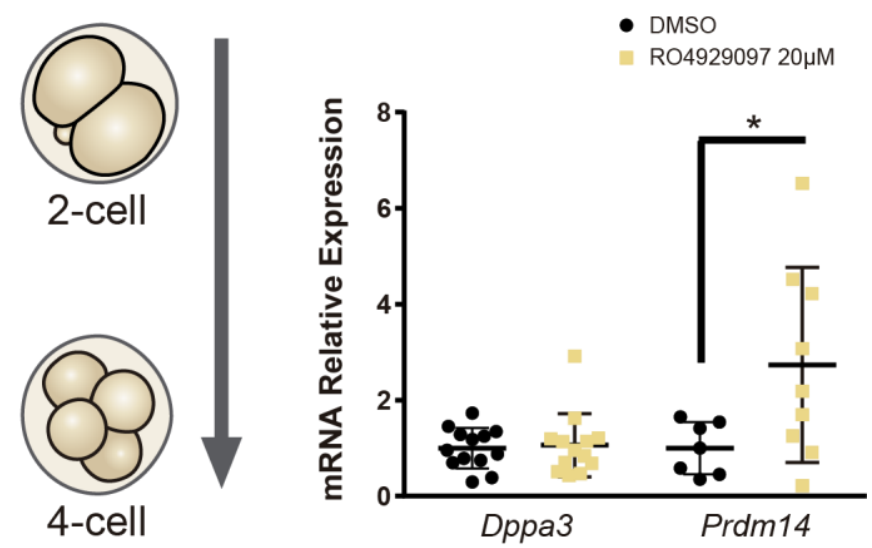

Figure 31. Notch inhibition increases Prdm14 expression. Dppa3 and Prdm14 relative expression in pools of 30 embryos after treatment with RO4929097 to block Notch from 2-cell to 4-cell stage. Pools of embryos treated with DMSO were used as controls. Data are means \pm s.d. ${ }^{*} p<0.05$ by Student's t-test. 


\subsection{Different Notch levels coordinate the transition from a naïve state to commitment for differentiation in ES cells}

Following the results obtained in the preimplantation embryo, we speculated if the blocking of naïve markers and guiding differentiation programs by Notch was also occurring in ES cells, where those naïve pluripotency markers are indeed present. We used iChr-Notch-Mosaic ES cells (Pontes-Quero et al., 2017) to confront populations with different Notch levels, following the same strategy than we had used in the embryo (Figure 32A). After recombination by cell transfection with a Cre expressing plasmid, ES cells were sorted according to the fluorescent reporter cassette they expressed (Figure 32B). We measured expression levels of naïve pluripotency markers by RT-qPCR in sorted populations, and found that levels of Prdm14 and Dppa3 correlated negatively with Notch activity but other markers such as Nanog or Esrrb were not affected (Figure 32C). 
A

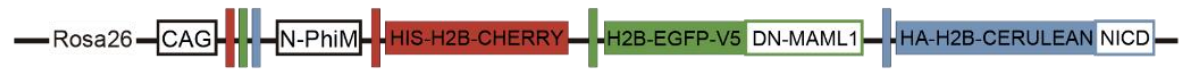

B

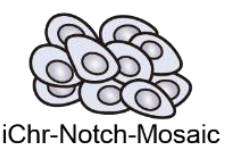

Cre
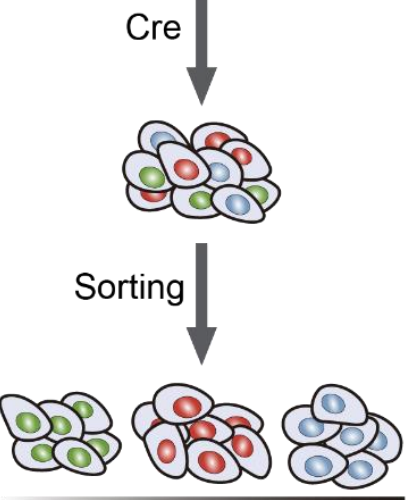

Notch activity
C
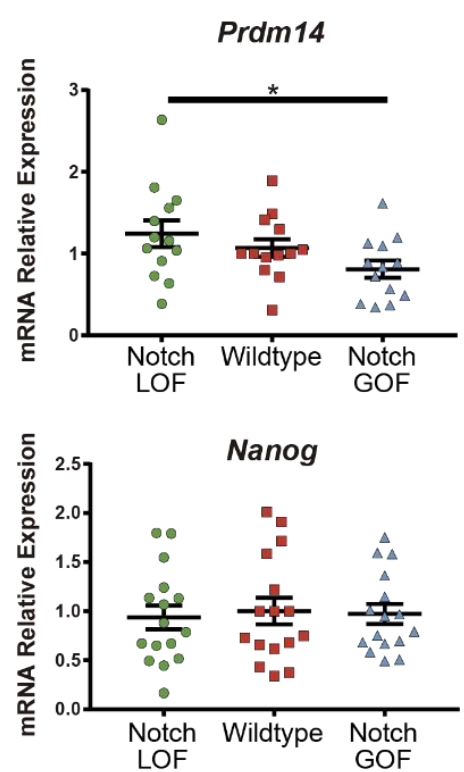
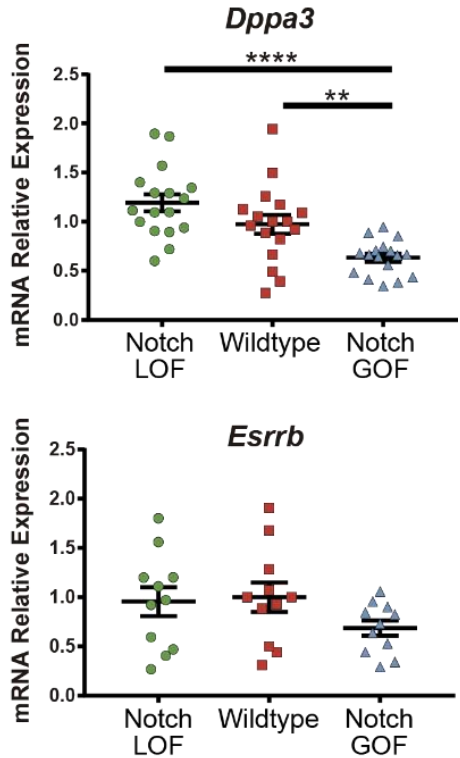

Figure 32. Notch levels correlate negatively with naïve pluripotency. (A) Construct showing the wildtype (red), Notch loss of function (green) and Notch gain of function (blue) cassettes from iChr-Notch-Mosaic ES cells. (B) Schematic diagram of experimental design, where iChr-Notch-Mosaic ES cells were recombined with Cre and sorted according to Notch activity. (C) Prdm14, Dppa3, Nanog and Esrrb relative expression in iChr-Notch-Mosaic ES cells after sorting of Notch LOF, Wildtype and Notch GOF populations ( $\mathrm{n}=13$ for Prdm14, $\mathrm{n}=17$ for Dppa3, $\mathrm{n}=16$ for Nanog, $\mathrm{n}=11$ for Esrrb). Data are means \pm s.e.m. ${ }^{*} p<0.05,{ }^{* *} p<0.01,{ }^{* \star *} \mathrm{p}<0.0001$ by ANOVA with Fisher post-test.

We next asked how Notch would affect the differentiation potential of pluripotent cells using this system. To do that, we allowed sorted iChr-Notch-Mosaic ES cells to spontaneously differentiate, and analysed the expression of genes related to early differentiation events at 12, 24 and 48 hours after LIF withdrawal (Figure 33A). On the one hand, we observed that the peak of expression of Tle4 and the early epiblast markers Fgf5 and Pou3f1 occurred earlier and remained at higher levels in Notch GOF than in wildtype ES cells. On the other, Notch LOF cells did not reach normal levels of $T b \times 3$ or Fgf5 during the differentiation process (Figure 33B). 
A

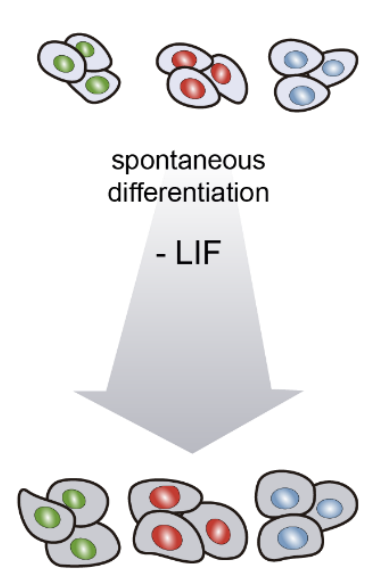

C

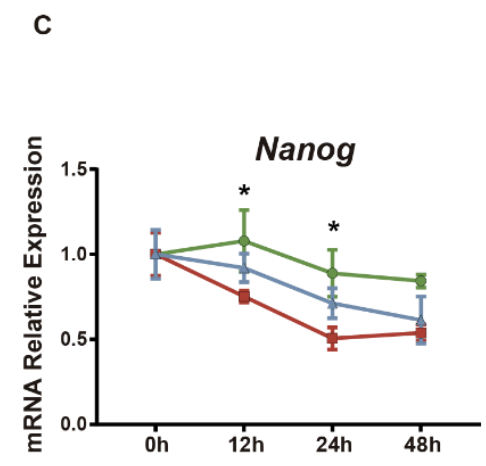

B
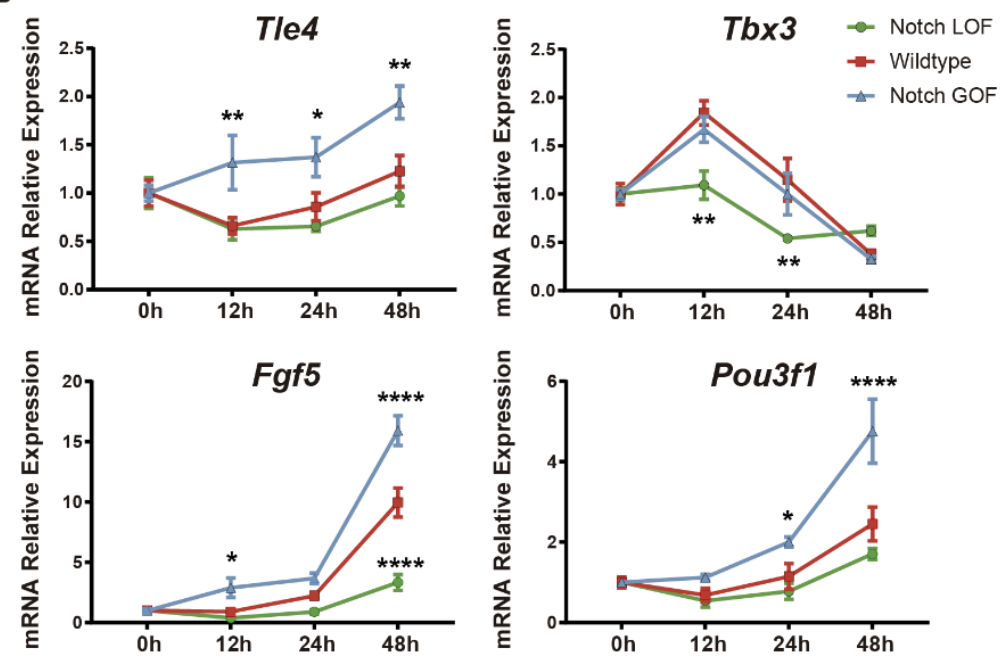

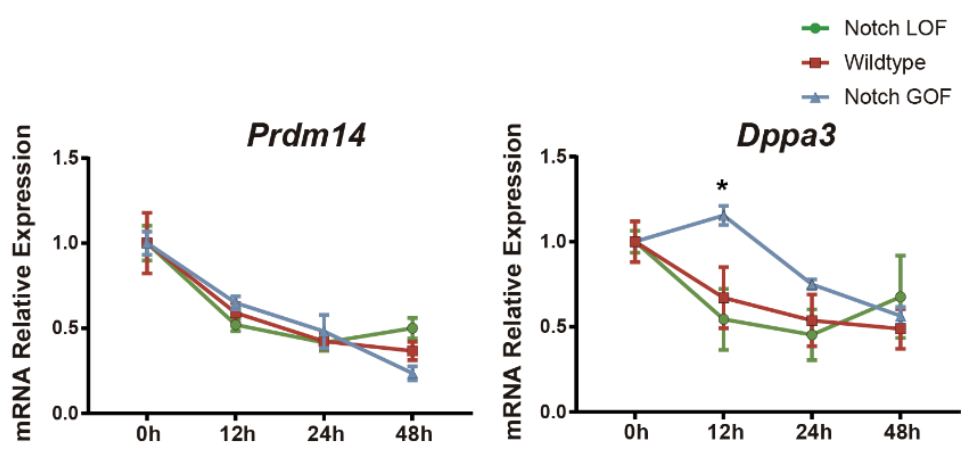

Figure 33. Notch promotes cell differentiation of ES cells. (A) Schematic diagram of experimental design, where sorted recombined iChr-Notch-Mosaic ES cells were differentiated after LIF removal. (B) Tle4, Tbx3, Fgf5 and Pou3f1 relative expression in Notch LOF, wildtype and Notch GOF cells at $0 \mathrm{~h}, 12 \mathrm{~h}, 24 \mathrm{~h}$ and $48 \mathrm{~h}$ after LIF withdrawal to promote differentiation $(\mathrm{n}=6)$. (C) Nanog, Prdm14 and Dppa3 relative expression in Notch LOF, wildtype and Notch GOF ES cells at $0 \mathrm{~h}, 12 \mathrm{~h}, 24 \mathrm{~h}$ and $48 \mathrm{~h}$ after LIF withdrawal $(n=6)$. Data are means \pm s.e.m. * $p<0.05$, ** $p<0.01,{ }^{* * * *} p<0.0001$ by ANOVA with Fisher post-test.

These results show that Notch is not only sufficient to promote expression of differentiation markers such as T/e4, but also necessary to achieve proper levels of others such as Tbx3. However, modulation of Notch levels does not prevent, in general, pluripotency markers to decline once ES cells have been pushed to differentiate (Figure 33C). Overall, our results suggest that Notch is involved in coordinating exit from pluripotency and promoting cell differentiation in ES cells, mirroring its role in the preimplantation embryo. 


\section{Expression of Notch pathway components in the preimplantation embryo}

To have a clear understanding on how Notch signalling is acting during preimplantation development, an important aspect is to investigate which components of the pathway are involved in its activity. As described in the introduction, there are four Notch receptors and five ligands from two different families (Delta-like and Jagged) in mammals, that interact between them and, together with other components, lead to the activation of the pathway (see Box 2). In order to know which of them were expressed at the stages under study, we took advantage of RNA-seq data from control embryos at morula stage and from RNA-seq data generated in the laboratory at blastocyst stage. We selected a list including the most relevant genes coding for receptors, ligands and other regulators such as Mastermind-like proteins (Mam) or Mind bomb factors (Mib), and analysed their expression in morula and blastocyst stages (Figure 34).

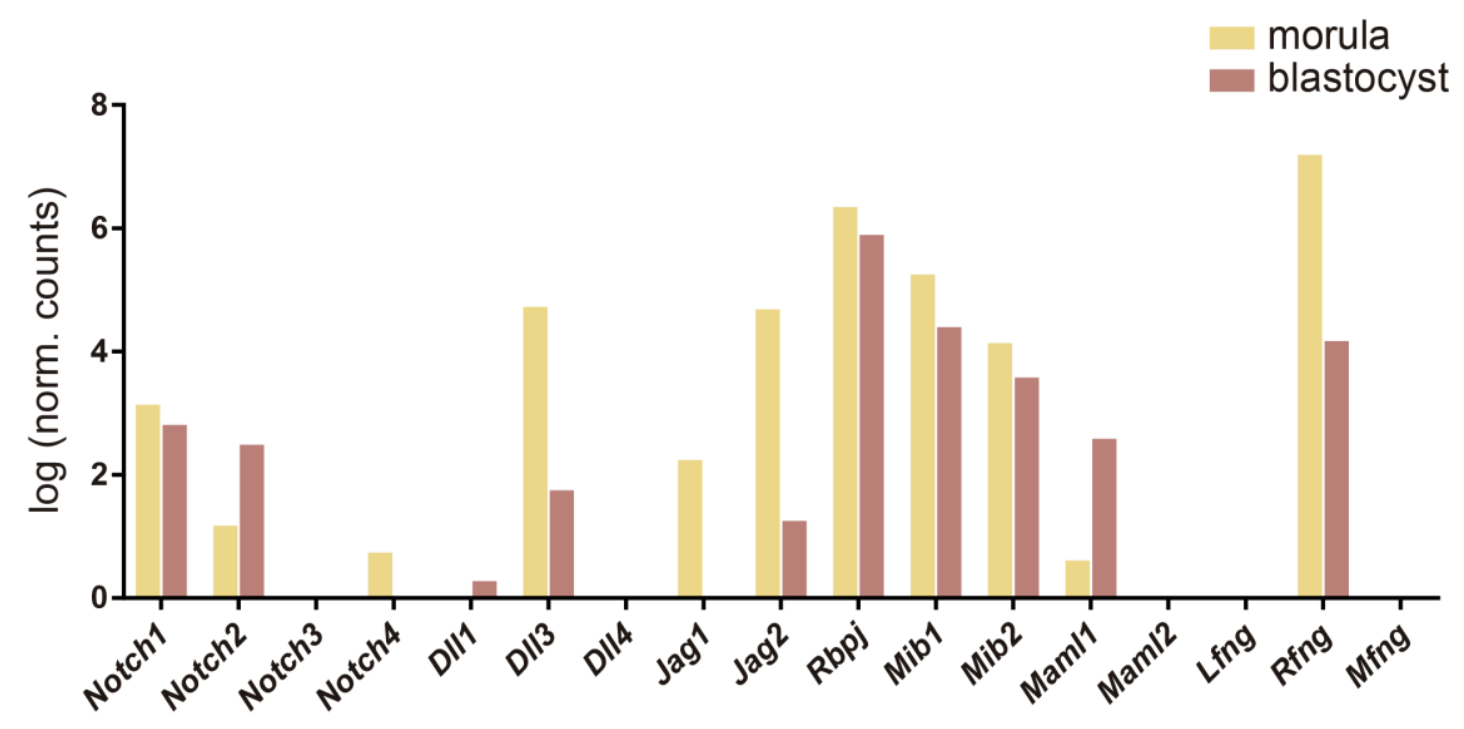

Figure 34. Expression of Notch pathway components in the preimplantation embryo. Normalized expression levels of the main components of the Notch pathway at morula and blastocyst stage.

We observed that most of the genes analysed are expressed at both stages. Notch1 is expressed in both stages as we have previously shown using a N1ICD antibody (Figure 10), although it is not the only receptor present as Notch2 is also expressed in the morula 
and blastocyst stage. As for ligands, D//3 and Jag2 are expressed at both stages, while D//1 is only expressed in the blastocyst and Jag1 is only detected in the morula, suggesting that different combinations of ligands and receptors may act throughout preimplantation development. It is also remarkable that the coactivator Mam/1 is the only member of its family expressed and, similarly, Rfng is likely the family member in charge of glycosylation of Notch receptors in these early stages.

In the blastocyst, we previously showed that the Notch pathway was specifically active in the TE since N1ICD and CBF1-VENUS expression are restricted to this lineage (Figure 10 and 11). We wondered if other components would be differentially expressed between TE and ICM to achieve this restricted activity. We examined the expression of two ligands in the blastocyst: Jag2, which was expressed in both morula and blastocyst stage, and DIII that was specifically expressed in the blastocyst (Figure 34). By means of fluorescent in situ hybridisation assays we observed that Jag2 was highly expressed in the ICM while D/l1 had a more homogenous pattern throughout the whole blastocyst (Figure 35), suggesting that they could have different roles in regulating the pathway in the blastocyst.
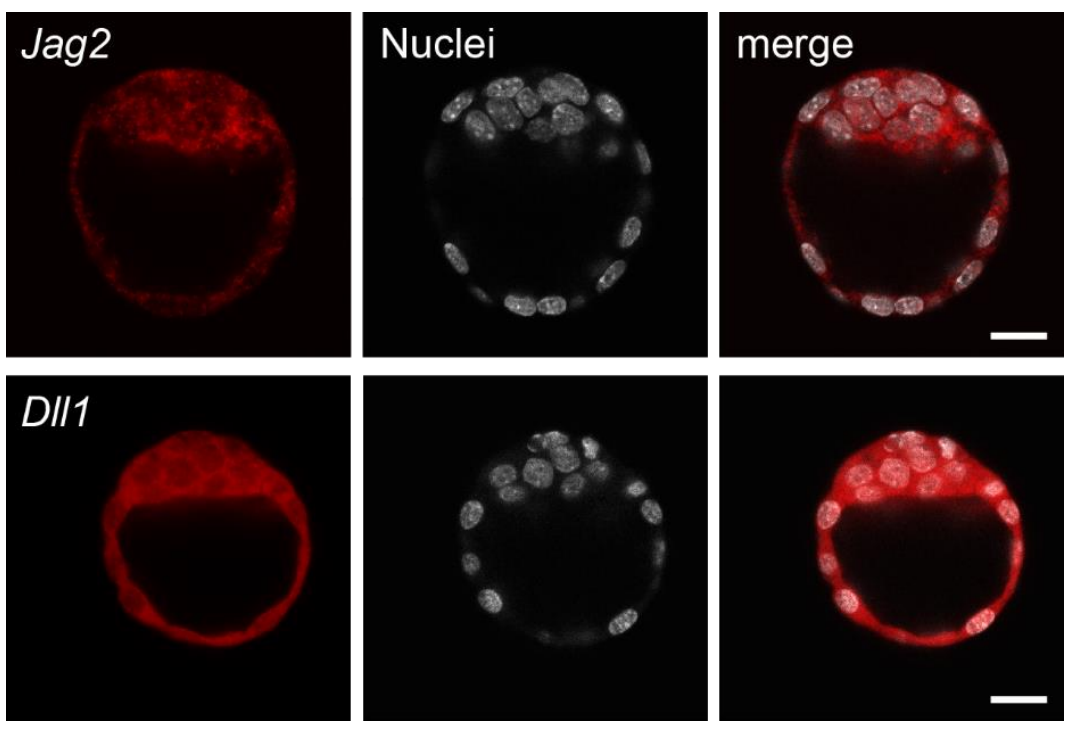

Figure 35. Jag2 and DII1 expression in the blastocyst. Fluorescent in situ hybridisation of Jag2 and D/II in the blastocyst. Nuclei were stained with DAPI. Scale bars, $20 \mu \mathrm{m}$. 
Taken all together, in this work we have investigated how the mouse embryo specifies its first lineages. Through the use of different mutant alleles, live imaging, single-embryo RNA-seq, transgenesis and mutagenesis of regulatory elements, and pluripotent stem cell culture assays, we have unveiled a role for the Notch pathway driving the transition towards a more committed state before the establishment of the first cell fates. By blocking naïve markers such as Prdm14, Notch allows blastomeres to pass from a more plastic state to trigger lineage programs. In the morula, it has a key role in the regulation of $C d x 2$, which is later reinforced by the input of the Hippo pathway to determine the trophectoderm lineage. This thesis reflects how different signalling pathways work together to regulate cell fate. 


\section{DISCUSSION}




\section{Different signalling pathways work together to establish cell}

\section{fate}

During the first days of mammalian embryo development, the onset of cell differentiation takes over after the loss of the totipotent state to favour the emergence of the first committed populations: the trophectoderm (TE) and the inner cell mass (ICM). A circuitry of master transcription factors and morphological cues related to cell adhesion and polarity are critical for the establishment and maintenance of these early lineages. The Hippo pathway is known to act as a readout of cell polarity and mediate the translation between this cellular phenotype and the expression of lineage-specifying markers (Sasaki, 2015). The differential activity of Hippo in polarised and unpolarised blastomeres together with the input of the Notch pathway regulate the expression of $C d x 2$, key element in the TE lineage (Rayon et al., 2014). In this work, we assessed the temporal modulation of the pathways to show that Notch and Hippo do not act redundantly but sequentially to pattern the expression of $C d \times 2$. TEAD4 and YAP, the transcriptional effectors of the Hippo pathway, activate $C d x 2$ in cells that have established an apical domain. However, the initial expression of $C d \times 2$ both in inner and outer cells (Dietrich and Hiiragi, 2007; Posfai et al., 2017) suggested that inputs other than Hippo would initially be acting because its expression could not be explained only by YAP/TEAD4 activity. In fact, previous reports have described that although in most Tead4 ${ }^{-1}$ blastocysts CDX2 is not detected, early Tead $^{-/-}$morulae retain CDX2 expression (Nishioka et al., 2008). In agreement with these observations, we found blastomeres in the morula that express CDX2 but do not have nuclear YAP. In this situation, expression of CDX2 is likely due to Notch activity as the CBF1-VENUS reporter, used as a proxy for activity of the pathway (Nowotschin et al., 2013), is present in those cells. The analysis of Rbpj and Notch1 mutants in early and late morulae, as well as pharmacological treatments of preimplantation embryos to block the pathway, further supports the notion that the input provided by Notch is necessary for the early phases of $C d \times 2$ expression. These results, together with the fact that Notch overexpression cannot fully rescue the Tead4 mutant phenotype, show that Notch and Hippo have non-redundant but partially overlapping roles in early and late phases of $C d \times 2$ expression respectively. 
Moreover, only double mutant morulae for Rbpj and Tead 4 completely lack CDX2, and all CDX2 positive cells have at least one of the two pathways active. These findings support a model whereby overlapping or complementary inputs from different signalling pathways provide robustness in the system, circumventing any disturbances and ensuring proper development (Menchero et al., 2017). In such a model, Notch regulates the early expression of $C d x 2$ and this is later reinforced by the input of Hippo signalling and together, they ensure the correct specification and maintenance of the TE.

Tead $^{/-}$embryos fail to cavitate properly and are unable to implant (Nishioka et al., 2008; Yagi et al., 2007), while $R b p j^{/-}$embryos are lethal in postimplantation stages ( E 9.0) (Souilhol et al., 2006). Therefore, the lethal phenotype of single mutants is exacerbated in double mutant embryos for Rbpj and Tead4, which die before the blastocyst stage (Rayon et al., 2014). Double mutant morulae showed a complete loss of CDX2 while cell compaction did not seem affected. It is unlikely that the earlier lethality is only due to the lack of CDX2 given that $C d \times 2^{\prime-}$ embryos reach the blastocyst stage (Strumpf et al., 2005). The role in metabolism and energy production that has been recently shown for Tead4 could also be, in part, responsible for this aggravated phenotype (Kumar et al., 2018). Further analysis may give more insight on this interaction.

During embryonic development as well as in other biological processes such as cell-cell communication, cancer or inflammation, different signalling pathways have been shown to interact with each other to favour a specific phenotype (Ma and Hottiger, 2016; Ungefroren et al., 2018). The crosstalk between YAP and Notch has been studied in different cellular contexts (Totaro et al., 2018). YAP acts upstream of Notch in controlling epidermal stem cell or liver cell fate (Totaro et al., 2017; Yimlamai et al., 2014) while Notch is upstream of YAP in the corneal epithelium during chronic inflammation (Nowell et al., 2016). Also, YAP and Notch can cooperate to control the onset of oscillations in the segmentation clock (Hubaud et al., 2017) and they interact to promote the expression of Jag1 in smooth muscle cells (Manderfield et al., 2015). During TE establishment, YAP and NICD have also been shown to interact through SBNO1, and act synergistically to regulate $C d x 2$ (Watanabe et al., 2017). In this context, our results show that both pathways are acting in parallel since there is no correlation among YAP and CBF1-VENUS 
expression levels in single blastomeres in morula stage embryos. Nevertheless, several components of the Hippo pathway are downregulated in $R b p j^{/-}$morulae, so we cannot rule out the possibility of cross-transcriptional regulation between the pathways.

\section{Early activation of Notch signalling}

The role of Notch signalling in the specification of cell fates during development has been widely studied (Koch et al., 2013). Notch promotes heterogeneities and reinforces differences between neighbouring cells, which contributes to the segregation of cell fates in multiple processes and in different species (Artavanis-Tsakonas et al., 1999). The heterogeneous activity of the CBF-VENUS reporter in 4-cell stage embryos coincides with the loss of cell equivalence and emergence of differences among blastomeres. The asymmetrical activity of Notch in early development has also been reported in zebrafish and Xenopus, where Notch1 is enriched in the ventral part from the beginning of embryogenesis and represents the earliest sign of ventral specification (Castro Colabianchi et al., 2018). Other factors have been shown to be differentially expressed among blastomeres of the 4-cell mouse embryo (Burton et al., 2013; Goolam et al., 2016), suggesting that this is at this stage when cells lose their homogeneous state to desynchronize and start undertaking divergent developmental pathways. Interestingly, Prdm14, one of these factors, and Notch show divergent patterns of expression during multiple phases of embryo development. Prdm14 is first expressed at the 2- and 4-cell stage to be switched off in the morula, then re-expressed in the ICM of the blastocyst and later is restricted to the primordial germ cells (Burton et al., 2013; Yamaji et al., 2008). In contrast, the Notch pathway, as revealed by the CBF-VENUS reporter, begins to be active at the 4-cell stage, is active in most of the cells of the morula, and is later restricted to the TE of the blastocyst. After implantation, Notch activity is detected throughout the epiblast (Nowotschin et al., 2013). Therefore, the expression pattern of Prdm14 coincides with conditions where groups of cells show an undetermined state, while Notch is activated when cells transition towards their next developmental phase (Figure 36). Our 
results suggest that Notch would be regulating these transitions by downregulating Prdm14 expression.
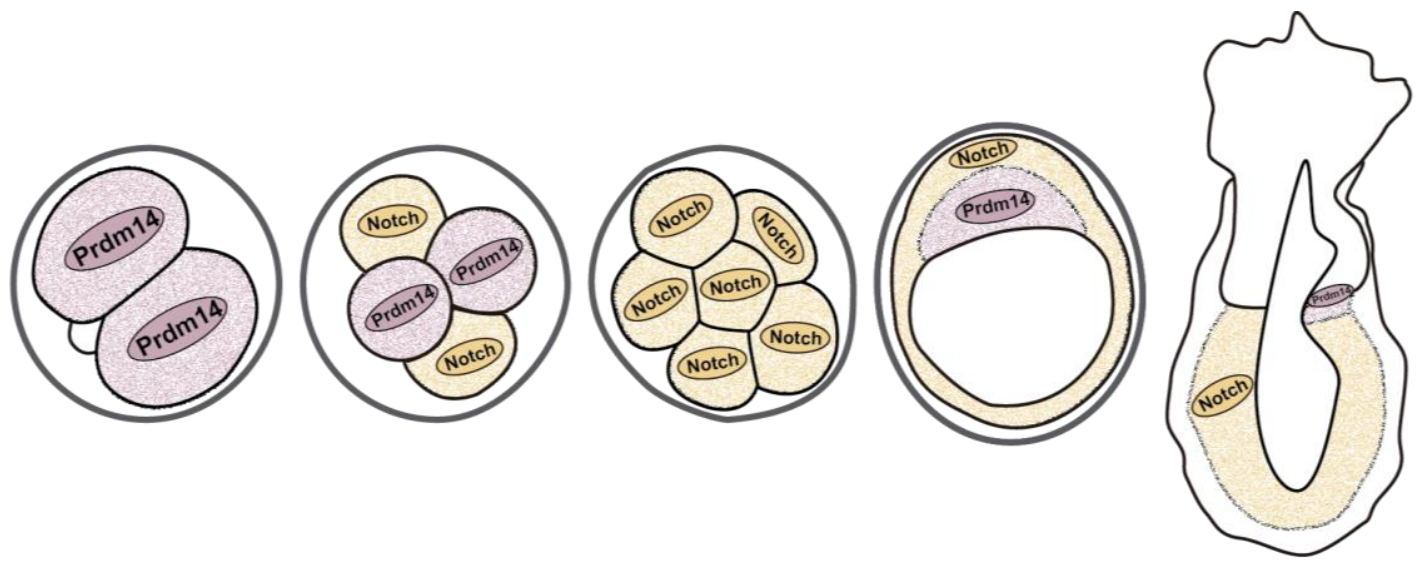

Figure 36. Divergent patterns of expression between Prdm14 and Notch activity. Schematic representation of early stages of mouse development from the 2-cell up to the early postimplantation embryo (E 6.5) showing pattern of expression of Prdm14 (purple) and Notch activity (yellow).

\section{Triggering of cell differentiation}

The transcriptome profiling performed in wildtype and Rbpj mutant morulae revealed that the role of Notch signalling during preimplantation stages is not limited to establish the TE lineage at the expense of the ICM lineage. Beyond the downregulation of TE markers such as $C d x 2$, Gata2 or Gata3, several pluripotency markers were also downregulated (Sal/1, Sall4 or Tbx3). This, together with the upregulation of naïve markers like Prdm14 or Dppa3 lead us to propose that Notch is acting before the specification of the first lineages, boosting the general onset of cell differentiation in the embryo.

However, it is remarkable that when different Notch levels are confronted in the 4-cell stage embryo in our genetic mosaic experiments, higher Notch activity correlates with outer positions and thus, the TE lineage. Nevertheless it is also true that the TE is the first cell population to be differentiated in the embryo, while the ICM represents the pluripotent population and therefore, this observation is still consistent with the idea of Notch promoting differentiation. In this set of experiments, we also noticed that Notch 
could influence proliferation of blastomeres, since the number of Notch GOF cells is predominant at the expense of Notch LOF cells. Notch is known to affect proliferation in several developmental contexts, including intestinal progenitor cells, gastric epithelial cells or angiogenesis (Benedito et al., 2009; Demitrack and Samuelson, 2017; VanDussen et al., 2012). Interestingly, we did not find any change in the total number of cells in $R b p j$ or Notch1 mutant morulae as compared to their wildtype littermates which could indicate that only when confronting distinct Notch activity levels, the differences in proliferation capacities are exposed. Further investigation may clarify this aspect during preimplantation development.

In line with the upregulation of Prdm14 in embryos that lack Notch activity, the analysis of the RNA-seq showed a downregulation of Fgf receptors (FgfrI, 2 and 3) and DNA methyltransferases (Dnmt3b, Dnmt1b), which are known to be repressed by PRDM14 (Grabole et al., 2013; Yamaji et al., 2013). It is also interesting to note that in our mosaic ES cell experiments, Notch levels correlate with those of Prdm14 and Dppa3, but not with other pluripotency markers such as Nanog or Esrrb. Therefore, Notch is not simply turning off the general pluripotency network to promote differentiation, but acting on a subset of early naïve pluripotency markers.

The interplay between Notch and chromatin remodellers has been reported in several situations (Schwanbeck, 2015). Expression changes in chromatin modifiers precede the action of transcription factors that consolidate lineage choices during preimplantation development (Burton et al., 2013). Moreover, regulators of H3K9me3 heterochromatin that restrict cell plasticity and stemness, such as those encoded by Setdb1 or Suv39h (Yadav et al., 2018) are also downregulated in Notch loss of function morulae. The apparent dysregulation of chromatin opens a new set of questions that will require further investigation in order to elucidate how Notch can be mediating these changes. However, these alterations already suggest that Rbpjmutant embryos do not established correct epigenetic landscapes, do not turn off early markers such as Prdm14 or Dppa3 and are not able to properly trigger differentiation programmes leading to a delay in the expression of lineage specifiers such as $C d x 2$. 
The role of Notch in ES cells has already been explored in the context of neural differentiation (Lowell et al., 2006). A blockade in Notch signalling prevents ES cells from adopting a neural fate while its overexpression accelerates the frequency of neural specification. In light of our results, we consider that Notch might have a more general role in promoting early differentiation, with a more specific function in neural specification at later stages. In this work (Lowell et al., 2006), it is shown that Jag1, Jag2 and DI/3 are the ligands present in ES cells; interestingly, these are the same pathway components that we detect in the morula according to the RNA-seq analysis. Future studies on the mechanism by which Notch is being activated in the morula could reveal the role of these ligands and if they act similarly in the embryo and in ES cells.

\section{Novel targets of Notch: Tle4 and Tbx3}

In this thesis, we have also identified novel putative targets positively regulated by the Notch pathway, among them Tle4 and Tbx3. Their function as repressors has been studied in several contexts. TLE4 silences gamma interferon expression in tolerant T helper cells (Bandyopadhyay et al., 2014) and acts as tumour suppressor in myeloid leukaemia (Dayyani et al., 2008; Shin et al., 2016). TBX3 represses differentiation into ventricular myocardium to specify the atrioventricular conduction system (Bakker et al., 2008) and promotes melanoma cell invasion by repressing E-cadherin in melanocytes (Boyd et al., 2013). Interestingly, their role in ES cells is related with exit from pluripotency by repressing key pluripotency factors (Laing et al., 2015; Russell et al., 2015; Waghray et al., 2015). The increase in expression of both genes from the 2-cell to morula supports a possible role in promoting early differentiation in vivo as well. TLE4 does not bind directly to DNA, but associates with other proteins to act as a transcriptional corepressor (Kaul et al., 2015). It will be interesting to identify its transcriptional partners during preimplantation development and elucidate the mechanism by which it allows cell differentiation in this context. The role of TBX3 in the perspective of pluripotency is more complex given that, in addition to favour cell differentiation, it has also been associated with pluripotency maintenance (Han et al., 2010; Niwa et al., 2009). Furthermore, in vivo TBX3 is detected in most of the cells of the morula but it is later restricted to the ICM 
(Russell et al., 2015), therefore initially following an equivalent pattern to Notch activity, but a complementary pattern later in the blastocyst. Thus, $T b \times 3$ regulation must involve Notch-dependent and Notch-independent inputs. This could explain why the mutation or deletion of the RBPJ motif included in the intronic $T b \times 3$ regulatory element did not disrupt enhancer activity or endogenous expression. Other regulatory elements and other inputs may complement the transcriptional activity driven by this enhancer.

In light of the above findings and data from published literature, we can propose a network in which Notch, on one hand would activate the repressors Tle4 and Tbx3, which would block the expression of the naïve pluripotency markers Dppa3 and Prdm14; and on the other would promote the expression of $C d \times 2$. In embryos that have lost Notch signalling, the repressors are not fully activated, and the naïve markers are not turned down. Consequently, other factors repressed by PRDM14 such as Dnmt3b or Fgf receptors would be downregulated (Figure 37).

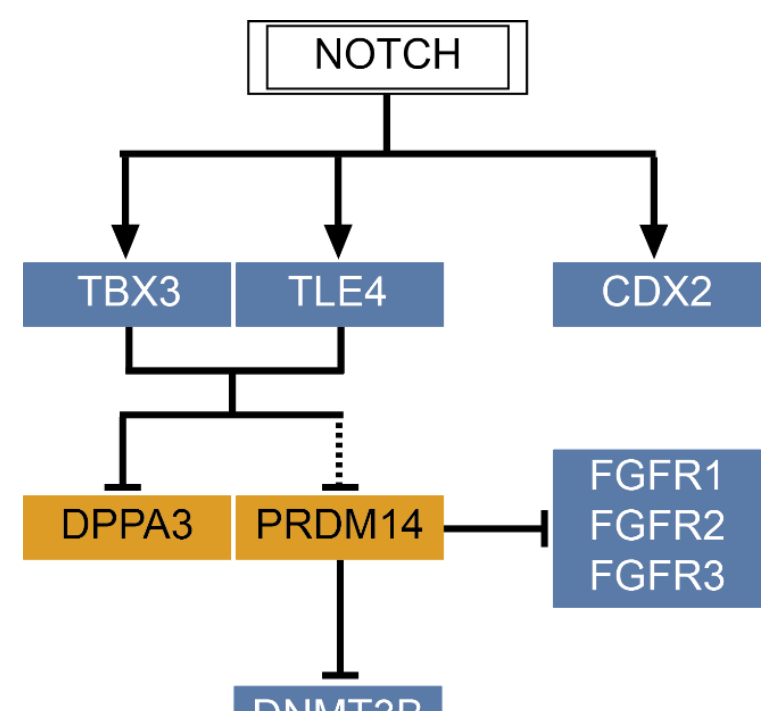

DNMT3B

Figure 37. Proposed network regulated by Notch signalling during mouse preimplantation development. Factors in blue boxes are downregulated and in yellow boxes upregulated in the RNA-seq analysis of Rbpj mutant morulae as compared to controls. 


\section{Notch drives transitions in cell potency during mouse preimplantation development}

During the first three days of embryonic development the mouse embryo must exit the totipotent state and gradually lose cell plasticity, and we propose that Notch signalling is mediating this transition. Our results suggest that Notch is underlying these events controlling the setup for the specification of cell fate by inducing a differentiation-prone state thanks to reduction of naïve marker levels first, and by activating lineage specifiers such as $C d \times 2$ later.

Notch signalling is known to operate through cell-cell interactions (trans) by two possible mechanisms: lateral inhibition and lateral induction. Lateral inhibition generates distinct cell fates from initially equivalent groups of neighbouring cells (Artavanis-Tsakonas et al., 1999) while lateral induction promotes neighbouring cells to adopt the same fate (LunaEscalante et al., 2018). Furthermore, signalling can also operate through ligand-receptor interaction within the same cell (cis) inducing either inhibitory (Fiuza et al., 2010; Sprinzak et al., 2010) or activating (Elowitz et al., 2018) responses. The mechanisms operating in the early embryo remain unknown but according to the expression pattern of the reporter for Notch activity we can speculate that lateral inhibition could drive the first responses of the signalling at the 4-cell stage, when Notch is heterogeneously activated. In this context, activation of Notch would start blocking the expression of the naïve markers. In this scenario, Notch receptor and ligand expression should be complementary, that is why blastomeres expressing the ligand would also express Prdm14 while blastomeres expressing the receptor (receiving the signal) would block Prdm14 expression (Figure 38). In the early morula, when the activity of Notch is expanded to all the blastomeres of the embryo, mechanisms of lateral induction or cisinduction could be involved. As a result, the naïve markers are turned down and $C d \times 2$ starts to be expressed in a polarity- and position-independent manner (Figure 38). Finally in the blastocyst, $C d \times 2$ expression is restricted to the outer layer and maintained by the combination of Notch and Hippo inputs which also have restricted their activity to the TE. In this case lateral induction mechanisms between cells of the TE and lateral inhibition mechanisms between TE and ICM cells could mediate the restricted spatial 
response (Figure 38). Future work on the study of specific ligand behaviour will help to clarify the mechanisms driving the activity of the Notch pathway in the preimplantation mouse embryo.
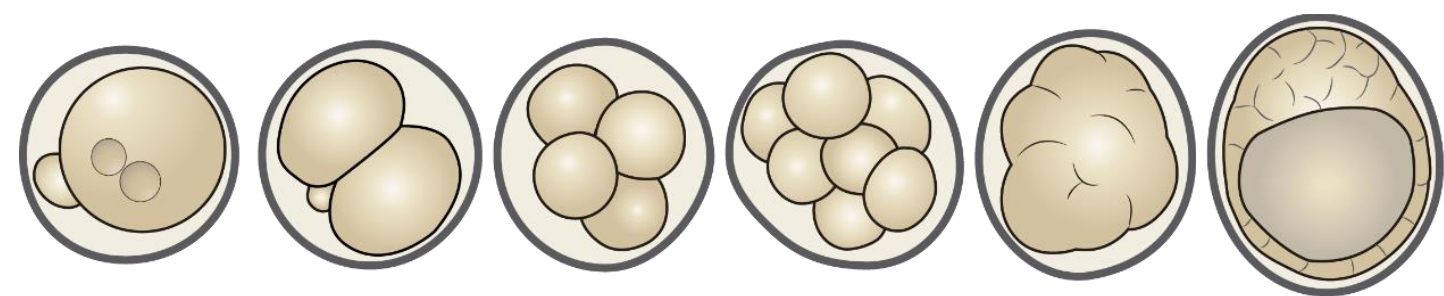

\section{HIPPO PATHWAY}

\section{NOTCH PATHWAY}
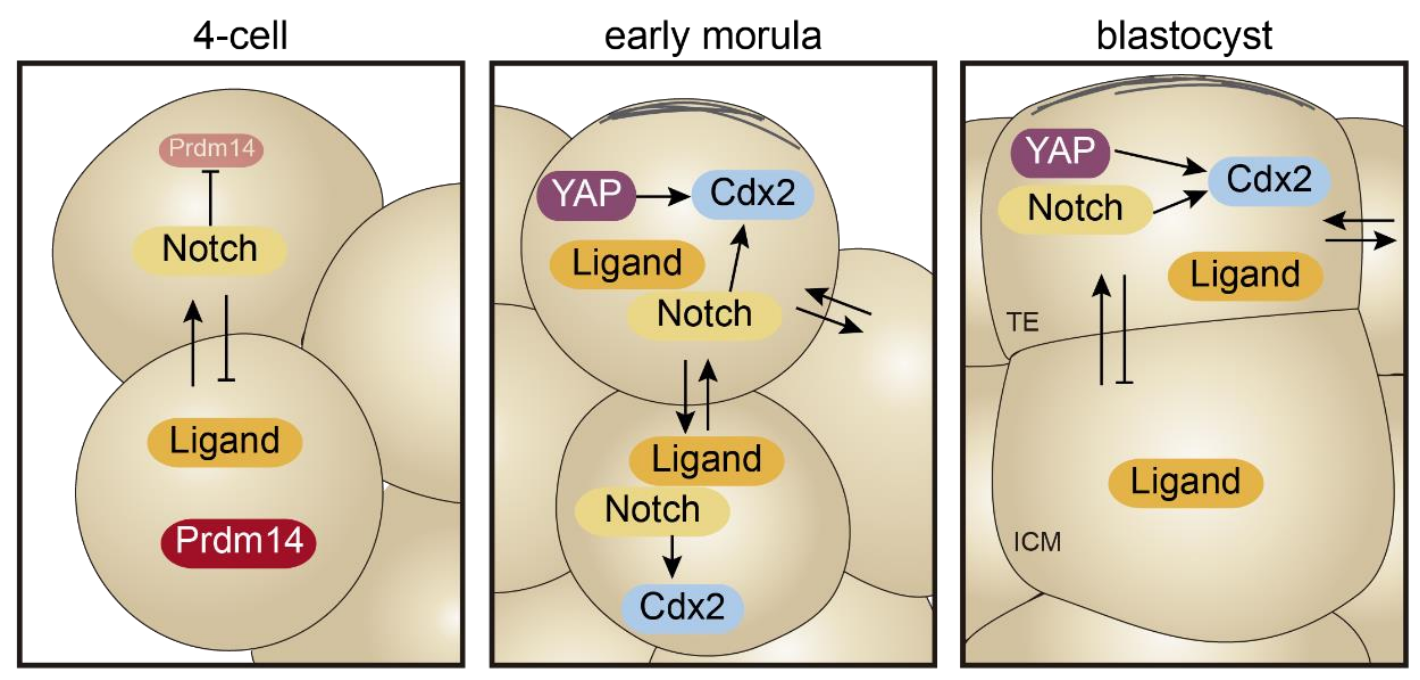

Figure 38. Temporal activity of the Notch pathway during preimplantation development. Proposed model explaining the activity of Notch signalling in the early mouse embryo. In the 4-cell stage, Notch acts through lateral inhibition to block Prdm14 and generate heterogeneities (left panel). In the early morula, and through lateral induction, Notch induces polarity-independent $C d \times 2$ expression (middle panel). In the blastocyst, the Hippo pathway translates polarity cues into transcriptional responses activating $C d \times 2$ through YAP in the TE, and Notch reinforces this signal maintaining its activity in the TE through lateral induction between TE cells and through lateral inhibition between TE and ICM cells (right panel). 
CONCLUSIONS 
1. $C d \times 2$ expression in the mouse preimplantation embryo requires the input from Hippo and Notch signalling pathways.

2. Notch regulates the early expression of $\mathrm{Cd} \times 2$ that is later reinforced by the input of Hippo.

3. Notch and Hippo pathways act in parallel in a non-redundant and sequential manner.

4. The Notch pathway is heterogeneously active before compaction, starting in the 4-cell stage embryo, and different levels of activity between inner and outer cells are already detected in the morula.

5. Different Notch activity levels in blastomeres of the 4-cell embryo drive the position of the descendant cells in the morula and in the blastocyst. High Notch activity predisposes cells to adopt an outer position while low Notch activity prompts an inner position.

6. Notch directly regulates the expression of the co-repressor Tle4 in the morula through an enhancer located upstream of the gene.

7. Exit of pluripotency in mouse embryonic stem cells is boosted by Notch.

8. Notch blocks naïve pluripotency markers and triggers cell differentiation events in the mouse preimplantation embryo. 


\section{CONCLUSIONES}

1. La expresión de $C d x 2$ en el embrión preimplantacional de ratón requiere la participación de las vías de señalización de Hippo y Notch.

2. Notch regula la expresión inicial de $C d x 2$ que es reforzada más tarde por la acción de Hippo.

3. Las vías de Notch y Hippo actúan en paralelo de manera no redundante y secuencialmente.

4. La vía de Notch se active heterogéneamente antes de la compactación, empezando en el embrión de 4 células. En la mórula se detectan diferentes niveles de actividad entre células internas y externas.

5. Diferentes niveles de actividad de Notch en blastómeros del embrión de 4 células dirigen la posición de sus células hijas en la mórula y en el blastocisto. Niveles altos de actividad de Notch predispone a las células a adquirir una posición exterior mientras que niveles bajos de actividad de Notch favorece una posición interior.

6. Notch regula directamente la expresión del correpresor Tle4 en la mórula a través de un elemento potenciador situado en posición $5^{\prime}$ del gen.

7. La salida del estado pluripotente en células troncales embrionarias de ratón está promovida por la actividad de Notch.

8. Notch bloquea marcadores de pluripotencia naíf y desencadena eventos de diferenciación celular en el embrión preimplantacional de ratón. 
Abranches, E., Bekman, E., and Henrique, D. (2013). Generation and Characterization of a Novel Mouse Embryonic Stem Cell Line with a Dynamic Reporter of Nanog Expression. PLoS One 8, e59928.

Anani, S., Bhat, S., Honma-Yamanaka, N., Krawchuk, D., and Yamanaka, Y. (2014). Initiation of Hippo signaling is linked to polarity rather than to cell position in the pre-implantation mouse embryo. Development 141, 2813-2824.

Andrey, G., and Mundlos, S. (2017). The three-dimensional genome: regulating gene expression during pluripotency and development. Development 144, 3646-3658.

Artavanis-Tsakonas, S., Rand, M.D., and Lake, R.J. (1999). Notch signaling: cell fate control and signal integration in development. Science $284,770-776$.

Avilion, A.A., Nicolis, S.K., Pevny, L.H., Perez, L., Vivian, N., and Lovell-Badge, R. (2003). Multipotent cell lineages in early mouse development depend on SOX2 function. Genes Dev 17, 126-140.

Bakker, M.L., Boukens, B.J., Mommersteeg, M.T.M., Brons, J.F., Wakker, V., Moorman, A.F.M., and Christoffels, V.M. (2008). Transcription Factor Tbx3 Is Required for the Specification of the Atrioventricular Conduction System. Circ. Res. 102, 1340-1349.

Bandyopadhyay, S., Valdor, R., and Macian, F. (2014). Tle4 Regulates Epigenetic Silencing of Gamma Interferon Expression during Effector T Helper Cell Tolerance. Mol. Cell. Biol. $34,233-245$.

Banerji, J., Rusconi, S., and Schaffner, W. (1981). Expression of a beta-globin gene is enhanced by remote SV40 DNA sequences. Cell 27, 299-308.

Baruni, J.K., Munro, E.M., and von Dassow, G. (2008). Cytokinetic furrowing in toroidal, binucleate and anucleate cells in C. elegans embryos. J. Cell Sci. 121, 306-316.

Beddington, R.S., and Robertson, E.J. (1989). An assessment of the developmental potential of embryonic stem cells in the midgestation mouse embryo. Development 105, 733-737.

Behringer, R., Gertsenstein, M., Vintersten Nagy, K., and Nagy, A. (2014). Manipulating the Mouse Embryo: A Laboratory Manual (New York: John Inglis).

Benahmed, F., Gross, I., Gaunt, S.J., Beck, F., Jehan, F., Domon-Dell, C., Martin, E., Kedinger, M., Freund, J., and Duluc, I. (2008). Multiple Regulatory Regions Control the Complex Expression Pattern of the Mouse Cdx2 Homeobox Gene. Gastroenterology 135, 12381247.e3.

Benedito, R., Roca, C., Sörensen, I., Adams, S., Gossler, A., Fruttiger, M., and Adams, R.H. (2009). The Notch Ligands DIl4 and Jagged1 Have Opposing Effects on Angiogenesis. Cell 137, 1124-1135. 
Blakeley, P., Fogarty, N.M.E., del Valle, I., Wamaitha, S.E., Hu, T.X., Elder, K., Snell, P., Christie, L., Robson, P., and Niakan, K.K. (2015). Defining the three cell lineages of the human blastocyst by single-cell RNA-seq. Development 142, 3151-3165.

Boyd, S.C., Mijatov, B., Pupo, G.M., Tran, S.L., Gowrishankar, K., Shaw, H.M., Goding, C.R., Scolyer, R.A., Mann, G.J., Kefford, R.F., et al. (2013). Oncogenic B-RAFV600E Signaling Induces the T-Box3 Transcriptional Repressor to Repress E-Cadherin and Enhance Melanoma Cell Invasion. J. Invest. Dermatol. 133, 1269-1277.

Buenrostro, J.D., Giresi, P.G., Zaba, L.C., Chang, H.Y., and Greenleaf, W.J. (2013). Transposition of native chromatin for fast and sensitive epigenomic profiling of open chromatin, DNA-binding proteins and nucleosome position. Nat. Methods 10, 12131218.

Buettner, K.A. (2007). Karl Ernst von Baer (1792-1876).

Burton, A., and Torres-Padilla, M.-E. (2014). Chromatin dynamics in the regulation of cell fate allocation during early embryogenesis. Nat. Rev. Mol. Cell Biol. 15, 723-735.

Burton, A., Muller, J., Tu, S., Padilla-Longoria, P., Guccione, E., and Torres-Padilla, M.-E. (2013). Single-Cell Profiling of Epigenetic Modifiers Identifies PRDM14 as an Inducer of Cell Fate in the Mammalian Embryo. Cell Rep. 5, 687-701.

Cao, Z., Carey, T.S., Ganguly, A., Wilson, C.A., Paul, S., and Knott, J.G. (2015). Transcription factor AP-2gamma induces early $\mathrm{Cdx2}$ expression and represses HIPPO signaling to specify the trophectoderm lineage. Development 142, 1606-1615.

Castro Colabianchi, A.M., Revinski, D.R., Encinas, P.I., Baez, M.V., Monti, R.J., Rodríguez Abinal, M., Kodjabachian, L., Franchini, L.F., and López, S.L. (2018). Notch1 is asymmetrically distributed from the beginning of embryogenesis and controls the ventral center. Development 145, dev159368.

Catarino, R.R., and Stark, A. (2018). Assessing sufficiency and necessity of enhancer activities for gene expression and the mechanisms of transcription activation. Genes Dev. 32, 202-223.

Chambers, I., Colby, D., Robertson, M., Nichols, J., Lee, S., Tweedie, S., and Smith, A. (2003). Functional expression cloning of Nanog, a pluripotency sustaining factor in embryonic stem cells. Cell 113, 643-655.

Cockburn, K., Biechele, S., Garner, J., and Rossant, J. (2013). The Hippo pathway member $\mathrm{Nf2}$ is required for inner cell mass specification. Curr Biol 23, 1195-1201.

Condic, M.L. (2016). The Role of Maternal-Effect Genes in Mammalian Development: Are Mammalian Embryos Really an Exception? Stem Cell Rev. Reports 12, 276-284.

Conlon, R.A., Reaume, A.G., and Rossant, J. (1995). Notch1 is required for the coordinate 
segmentation of somites. Development 121, 1533-1545.

Davidson, E.H. (1989). Lineage-specific gene expression and the regulative capacities of the sea urchin embryo: a proposed mechanism. Development 105.

Davidson, E.H. (1990). How embryos work: a comparative view of diverse modes of cell fate specification. Development 108.

Dayyani, F., Wang, J., Yeh, J.-R.J., Ahn, E.-Y., Tobey, E., Zhang, D.-E., Bernstein, I.D., Peterson, R.T., and Sweetser, D.A. (2008). Loss of TLE1 and TLE4 from the del(9q) commonly deleted region in AML cooperates with AML1-ETO to affect myeloid cell proliferation and survival. Blood 111, 4338-4347.

Demitrack, E.S., and Samuelson, L.C. (2017). Notch as a Driver of Gastric Epithelial Cell Proliferation. Cell. Mol. Gastroenterol. Hepatol. 3, 323-330.

Dietrich, J.E., and Hiiragi, T. (2007). Stochastic patterning in the mouse pre-implantation embryo. Development 134, 4219-4231.

Elowitz, M.B., Santat, L.A., and Nandagopal, N. (2018). Cis-activation in the Notch signaling pathway. BioRxiv 313171.

Evans, M.J., and Kaufman, M.H. (1981). Establishment in culture of pluripotential cells from mouse embryos. Nature 292, 154-156.

Fernández-de-Manúel, L., Díaz-Díaz, C., Jiménez-Carretero, D., Torres, M., and Montoya, M.C. (2017). ESC-Track: A computer workflow for 4-D segmentation, tracking, lineage tracing and dynamic context analysis of ESCs. Biotechniques 62, 215-222.

Fiuza, U.-M., Klein, T., Martinez Arias, A., and Hayward, P. (2010). Mechanisms of ligandmediated inhibition in Notch signaling activity in Drosophila. Dev. Dyn. 239, 798-805.

Gasnier, M., Dennis, C., Vaurs-Barrière, C., and Chazaud, C. (2013). Fluorescent mRNA labeling through cytoplasmic FISH. Nat. Protoc. 8, 2538-2547.

Gilbert, S.F. (2017). Developmental biology, the stem cell of biological disciplines. PLOS Biol. 15, e2003691.

Gildor, T., Hinman, V., and Ben-Tabou-De-Leon, S. (2017). Regulatory heterochronies and loose temporal scaling between sea star and sea urchin regulatory circuits. Int. J. Dev. Biol. 61, 347-356.

Goolam, M., Scialdone, A., Graham, S.J., Macaulay, I.C., Jedrusik, A., Hupalowska, A., Voet, T., Marioni, J.C., and Zernicka-Goetz, M. (2016). Heterogeneity in Oct4 and Sox2 Targets Biases Cell Fate in 4-Cell Mouse Embryos. Cell 165, 61-74.

Grabole, N., Tischler, J., Hackett, J.A., Kim, S., Tang, F., Leitch, H.G., Magnúsdóttir, E., and Surani, M.A. (2013). Prdm14 promotes germline fate and naive pluripotency by repressing 
FGF signalling and DNA methylation. EMBO Rep. 14, 629-637.

Grant, C.E., Bailey, T.L., and Noble, W.S. (2011). FIMO: scanning for occurrences of a given motif. Bioinformatics 27, 1017-1018.

Guerra, C., Mijimolle, N., Dhawahir, A., Dubus, P., Barradas, M., Serrano, M., Campuzano, $V_{\text {., }}$ and Barbacid, M. (2003). Tumor induction by an endogenous $\mathrm{K}$-ras oncogene is highly dependent on cellular context. Cancer Cell 4, 111-120.

Guo, G., Huss, M., Tong, G.Q., Wang, C., Li Sun, L., Clarke, N.D., and Robson, P. (2010). Resolution of cell fate decisions revealed by single-cell gene expression analysis from zygote to blastocyst. Dev Cell 18, 675-685.

Hackett, J.A., and Surani, M.A. (2014). Regulatory Principles of Pluripotency: From the Ground State Up. Cell Stem Cell 15, 416-430.

Haeussler, M., Schönig, K., Eckert, H., Eschstruth, A., Mianné, J., Renaud, J.-B., SchneiderMaunoury, S., Shkumatava, A., Teboul, L., Kent, J., et al. (2016). Evaluation of off-target and on-target scoring algorithms and integration into the guide RNA selection tool CRISPOR. Genome Biol. 17, 148.

Haffner-Krausz, R., Gorivodsky, M., Chen, Y., and Lonai, P. (1999). Expression of Fgfr2 in the early mouse embryo indicates its involvement in preimplantation development. Mech Dev 85, 167-172.

Han, H., Tanigaki, K., Yamamoto, N., Kuroda, K., Yoshimoto, M., Nakahata, T., Ikuta, K., and Honjo, T. (2002). Inducible gene knockout of transcription factor recombination signal binding protein-J reveals its essential role in T versus B lineage decision. Int. Immunol. 14, 637-645.

Han, J., Yuan, P., Yang, H., Zhang, J., Soh, B.S., Li, P., Lim, S.L., Cao, S., Tay, J., Orlov, Y.L., et al. (2010). Tbx3 improves the germ-line competency of induced pluripotent stem cells. Nature 463, 1096-1100.

Hayashi, K., Lopes, S.M.C. de S., Tang, F., Surani, M.A., and Surani, M.A. (2008). Dynamic Equilibrium and Heterogeneity of Mouse Pluripotent Stem Cells with Distinct Functional and Epigenetic States. Cell Stem Cell 3, 391-401.

Hayashi, S., Tenzen, T., and McMahon, A.P. (2003). Maternal inheritance of Cre activity in a Sox2Cre deleter strain. Genesis 37, 51-53.

Heintzman, N.D., Hon, G.C., Hawkins, R.D., Kheradpour, P., Stark, A., Harp, L.F., Ye, Z., Lee, L.K., Stuart, R.K., Ching, C.W., et al. (2009). Histone modifications at human enhancers reflect global cell-type-specific gene expression. Nature 459, 108-112.

Hirate, Y., Hirahara, S., Inoue, K., Suzuki, A., Alarcon, V.B., Akimoto, K., Hirai, T., Hara, T., Adachi, M., Chida, K., et al. (2013). Polarity-dependent distribution of angiomotin localizes 
Hippo signaling in preimplantation embryos. Curr Biol 23, 1181-1194.

Home, P., Ray, S., Dutta, D., Bronshteyn, I., Larson, M., and Paul, S. (2009). GATA3 is selectively expressed in the trophectoderm of peri-implantation embryo and directly regulates Cdx2 gene expression. J Biol Chem 284, 28729-28737.

Home, P., Kumar, R.P., Ganguly, A., Saha, B., Milano-Foster, J., Bhattacharya, B., Ray, S., Gunewardena, S., Paul, A., Camper, S.A., et al. (2017). Genetic redundancy of GATA factors in the extraembryonic trophoblast lineage ensures the progression of preimplantation and postimplantation mammalian development. Development 144, 876-888.

Huang, D., Guo, G., Yuan, P., Ralston, A., Sun, L., Huss, M., Mistri, T., Pinello, L., Ng, H.H., Yuan, G., et al. (2017). The role of $C d x 2$ as a lineage specific transcriptional repressor for pluripotent network during the first developmental cell lineage segregation. Sci. Rep. 7, 17156.

Hubaud, A., Regev, I., Mahadevan, L., and Pourquié, O. (2017). Excitable Dynamics and Yap-Dependent Mechanical Cues Drive the Segmentation Clock. Cell 171,668-682.e11.

Itoh, M., Kim, C.-H., Palardy, G., Oda, T., Jiang, Y.-J., Maust, D., Yeo, S.-Y., Lorick, K., Wright, G.J., Ariza-McNaughton, L., et al. (2003). Mind bomb is a ubiquitin ligase that is essential for efficient activation of Notch signaling by Delta. Dev. Cell 4, 67-82.

Johnson, M.H., and Ziomek, C.A. (1981). The foundation of two distinct cell lineages within the mouse morula. Cell 24,71-80.

Kalkan, T., and Smith, A. (2014). Mapping the route from naive pluripotency to lineage specification. Philos. Trans. R. Soc. B Biol. Sci. 369, 20130540-20130540.

Kaneko, K.J., and DePamphilis, M.L. (2013). TEAD4 establishes the energy homeostasis essential for blastocoel formation. Development 140, 3680-3690.

Karantzali, E., Lekakis, V., Ioannou, M., Hadjimichael, C., Papamatheakis, J., and Kretsovali, A. (2011). Sall1 Regulates Embryonic Stem Cell Differentiation in Association with Nanog. J. Biol. Chem. 286, 1037-1045.

Kaul, A.K., Schuster, E.F., and Jennings, B.H. (2015). Recent insights into Groucho corepressor recruitment and function. Transcription 6, 7-11.

Kelly, S.J. (1977). Studies of the developmental potential of 4- and 8-cell stage mouse blastomeres. J Exp Zool 200, 365-376.

Koch, U., Lehal, R., and Radtke, F. (2013). Stem cells living with a Notch. Development 140, 689-704.

Kono, K., Tamashiro, D.A.A., and Alarcon, V.B. (2014). Inhibition of RHO-ROCK signaling enhances ICM and suppresses TE characteristics through activation of Hippo signaling in 
the mouse blastocyst. Dev. Biol. 394, 142-155.

Kuckenberg, P., Buhl, S., Woynecki, T., van Furden, B., Tolkunova, E., Seiffe, F., Moser, M., Tomilin, A., Winterhager, E., and Schorle, H. (2010). The transcription factor TCFAP2C/AP2gamma cooperates with CDX2 to maintain trophectoderm formation. Mol Cell Biol 30, 3310-3320.

Kuckenberg, P., Peitz, M., Kubaczka, C., Becker, A., Egert, A., Wardelmann, E., Zimmer, A., Brustle, O., and Schorle, H. (2011). Lineage Conversion of Murine Extraembryonic Trophoblast Stem Cells to Pluripotent Stem Cells. Mol. Cell. Biol. 31, 1748-1756.

Kumar, R.P., Ray, S., Home, P., Saha, B., Bhattacharya, B., Wilkins, H.M., Chavan, H., Ganguly, A., Milano-Foster, J., Paul, A., et al. (2018). Regulation of energy metabolism during early mammalian development: TEAD4 controls mitochondrial transcription. Development dev.162644.

Laing, A.F., Lowell, S., and Brickman, J.M. (2015). Gro/TLE enables embryonic stem cell differentiation by repressing pluripotent gene expression. Dev. Biol. 397, 56-66.

Lawrence, P.A., and Levine, M. (2006). Mosaic and regulative development: two faces of one coin. Curr. Biol. 16, R236-R239.

Leung, C.Y., and Zernicka-Goetz, M. (2013). Angiomotin prevents pluripotent lineage differentiation in mouse embryos via Hippo pathway-dependent and -independent mechanisms. Nat Commun 4, 2251.

Li, B., and Dewey, C.N. (2011). RSEM: accurate transcript quantification from RNA-Seq data with or without a reference genome. BMC Bioinformatics 12, 323.

Lin, S.-C.J., Wani, M.A., Whitsett, J.A., and Wells, J.M. (2010). Klf5 regulates lineage formation in the pre-implantation mouse embryo. Development 137.

Liu-Chittenden, Y., Huang, B., Shim, J.S., Chen, Q., Lee, S.-J., Anders, R.A., Liu, J.O., and Pan, D. (2012). Genetic and pharmacological disruption of the TEAD-YAP complex suppresses the oncogenic activity of YAP. Genes Dev. 26, 1300-1305.

Lou, X., Kang, M., Xenopoulos, P., Muñoz-Descalzo, S., and Hadjantonakis, A.-K. (2014). A Rapid and Efficient 2D/3D Nuclear Segmentation Method for Analysis of Early Mouse Embryo and Stem Cell Image Data. Stem Cell Reports 2, 382-397.

Lowell, S., Benchoua, A., Heavey, B., and Smith, A.G. (2006). Notch promotes neural lineage entry by pluripotent embryonic stem cells. PLoS Biol. 4, e121.

Luna-Escalante, J.C., Formosa-Jordan, P., and Ibañes, M. (2018). Redundancy and cooperation in Notch intercellular signaling. Development 145, dev154807.

Ma, B., and Hottiger, M.O. (2016). Crosstalk between Wnt/ $\beta$-Catenin and NF- $\kappa B$ Signaling 
Pathway during Inflammation. Front. Immunol. 7, 378.

Macfarlan, T.S., Gifford, W.D., Driscoll, S., Lettieri, K., Rowe, H.M., Bonanomi, D., Firth, A., Singer, O., Trono, D., and Pfaff, S.L. (2012). Embryonic stem cell potency fluctuates with endogenous retrovirus activity. Nature 487, 57-63.

MacGrogan, D., Münch, J., and de la Pompa, J.L. (2018). Notch and interacting signalling pathways in cardiac development, disease, and regeneration. Nat. Rev. Cardiol. 1.

Maitre, J.L., Niwayama, R., Turlier, H., Nedelec, F., and Hiiragi, T. (2015). Pulsatile cellautonomous contractility drives compaction in the mouse embryo. Nat Cell Biol 17,849855 .

Maitre, J.L., Turlier, H., Illukkumbura, R., Eismann, B., Niwayama, R., Nedelec, F., and Hiiragi, T. (2016). Asymmetric division of contractile domains couples cell positioning and fate specification. Nature 536, 344-348.

Manderfield, L.J., Aghajanian, H., Engleka, K.A., Lim, L.Y., Liu, F., Jain, R., Li, L., Olson, E.N., and Epstein, J.A. (2015). Hippo signaling is required for Notch-dependent smooth muscle differentiation of neural crest. Development 142, 2962-2971.

Manzanares, M., and Rodriguez, T.A. (2013). Development: Hippo Signalling Turns the Embryo Inside Out. Curr. Biol. 23, R559-R561.

Martin, G.R. (1981). Isolation of a pluripotent cell line from early mouse embryos cultured in medium conditioned by teratocarcinoma stem cells. Proc Natl Acad Sci U S A 78, 76347638.

McDole, K., and Zheng, Y. (2012). Generation and live imaging of an endogenous Cdx2 reporter mouse line. Genesis 50, 775-782.

McDole, K., Xiong, Y., Iglesias, P.A., and Zheng, Y. (2011). Lineage mapping the preimplantation mouse embryo by two-photon microscopy, new insights into the segregation of cell fates. Dev Biol 355, 239-249.

Menchero, S., Rayon, T., Andreu, M.J., and Manzanares, M. (2017). Signaling pathways in mammalian preimplantation development: Linking cellular phenotypes to lineage decisions. Dev. Dyn. 246.

Menchero, S., Sainz de Aja, J., and Manzanares, M. (2018). Our First Choice: Cellular and Genetic Underpinnings of Trophectoderm Identity and Differentiation in the Mammalian Embryo. In Current Topics in Developmental Biology, pp. 59-80.

Meng, Z., Moroishi, T., and Guan, K.-L. (2016). Mechanisms of Hippo pathway regulation. Genes Dev. 30, 1-17.

Mihajlovic, A.I., and Bruce, A.W. (2016). Rho-associated protein kinase regulates 
subcellular localisation of Angiomotin and Hippo-signalling during preimplantation mouse embryo development. Reprod Biomed Online.

Mitsui, K., Tokuzawa, Y., Itoh, H., Segawa, K., Murakami, M., Takahashi, K., Maruyama, M., Maeda, M., and Yamanaka, S. (2003). The Homeoprotein Nanog Is Required for Maintenance of Pluripotency in Mouse Epiblast and ES Cells. Cell 113, 631-642.

Mlodzik, M., Fjose, A., and Gehring, W.J. (1985). Isolation of caudal, a Drosophila homeo box-containing gene with maternal expression, whose transcripts form a concentration gradient at the pre-blastoderm stage. Embo J 4, 2961-2969.

Morgani, S.M., Canham, M.A., Nichols, J., Sharov, A.A., Migueles, R.P., Ko, M.S.H., and Brickman, J.M. (2013). Totipotent Embryonic Stem Cells Arise in Ground-State Culture Conditions. Cell Rep. 3, 1945-1957.

Munch, J., Gonzalez-Rajal, A., and de la Pompa, J.L. (2013). Notch regulates blastema proliferation and prevents differentiation during adult zebrafish fin regeneration. Development 140, 1402-1411.

Murtaugh, L.C., Stanger, B.Z., Kwan, K.M., and Melton, D.A. (2003). Notch signaling controls multiple steps of pancreatic differentiation. Proc. Natl. Acad. Sci. U. S. A. 100, 14920-14925.

Nichols, J., Zevnik, B., Anastassiadis, K., Niwa, H., Klewe-Nebenius, D., Chambers, I., Scholer, H., and Smith, A. (1998). Formation of pluripotent stem cells in the mammalian embryo depends on the POU transcription factor Oct4. Cell 95, 379-391.

Nien, C.-Y., Liang, H.-L., Butcher, S., Sun, Y., Fu, S., Gocha, T., Kirov, N., Manak, J.R., and Rushlow, C. (2011). Temporal Coordination of Gene Networks by Zelda in the Early Drosophila Embryo. PLoS Genet. 7, e1002339.

Nikas, G., Ao, A., Winston, R.M., and Handyside, A.H. (1996). Compaction and surface polarity in the human embryo in vitro. Biol. Reprod. 55, 32-37.

Nishioka, N., Yamamoto, S., Kiyonari, H., Sato, H., Sawada, A., Ota, M., Nakao, K., and Sasaki, H. (2008). Tead4 is required for specification of trophectoderm in preimplantation mouse embryos. Mech Dev 125, 270-283.

Nishioka, N., Inoue, K., Adachi, K., Kiyonari, H., Ota, M., Ralston, A., Yabuta, N., Hirahara, S., Stephenson, R.O., Ogonuki, N., et al. (2009). The Hippo signaling pathway components Lats and Yap pattern Tead4 activity to distinguish mouse trophectoderm from inner cell mass. Dev Cell 16, 398-410.

Niwa, H., Miyazaki, J., and Smith, A.G. (2000). Quantitative expression of Oct-3/4 defines differentiation, dedifferentiation or self-renewal of ES cells. Nat. Genet. 24, 372-376.

Niwa, H., Toyooka, Y., Shimosato, D., Strumpf, D., Takahashi, K., Yagi, R., and Rossant, J. 
(2005). Interaction between Oct3/4 and Cdx2 determines trophectoderm differentiation. Cell 123, 917-929.

Niwa, H., Ogawa, K., Shimosato, D., and Adachi, K. (2009). A parallel circuit of LIF signalling pathways maintains pluripotency of mouse ES cells. Nature 460, 118-122.

Nowell, C.S., Odermatt, P.D., Azzolin, L., Hohnel, S., Wagner, E.F., Fantner, G.E., Lutolf, M.P., Barrandon, Y., Piccolo, S., and Radtke, F. (2016). Chronic inflammation imposes aberrant cell fate in regenerating epithelia through mechanotransduction. Nat. Cell Biol. 18, 168180.

Nowotschin, S., Xenopoulos, P., Schrode, N., and Hadjantonakis, A.K. (2013). A bright single-cell resolution live imaging reporter of Notch signaling in the mouse. BMC Dev Biol 13, 15.

Ohnishi, Y., Huber, W., Tsumura, A., Kang, M., Xenopoulos, P., Kurimoto, K., Oleś, A.K., Araúzo-Bravo, M.J., Saitou, M., Hadjantonakis, A.-K., et al. (2014). Cell-to-cell expression variability followed by signal reinforcement progressively segregates early mouse lineages. Nat. Cell Biol. 16, 27-37.

Oka, C., Nakano, T., Wakeham, A., de la Pompa, J.L., Mori, C., Sakai, T., Okazaki, S., Kawaichi, M., Shiota, K., Mak, T.W., et al. (1995). Disruption of the mouse RBP-J kappa gene results in early embryonic death. Development 121, 3291-3301.

Pan, D. (2010). The hippo signaling pathway in development and cancer. Dev Cell 19, 491-505.

Panin, V.M., Papayannopoulos, V., Wilson, R., and Irvine, K.D. (1997). Fringe modulates Notch-ligand interactions. Nature 387, 908-912.

Petropoulos, S., Edsgärd, D., Reinius, B., Deng, Q., Panula, S.P., Codeluppi, S., Plaza Reyes, A., Linnarsson, S., Sandberg, R., and Lanner, F. (2016). Single-Cell RNA-Seq Reveals Lineage and X Chromosome Dynamics in Human Preimplantation Embryos. Cell 165, 1012-1026.

Pontes-Quero, S., Heredia, L., Casquero-García, V., Fernández-Chacón, M., Luo, W., Hermoso, A., Bansal, M., Garcia-Gonzalez, I., Sanchez-Muñoz, M.S., Perea, J.R., et al. (2017). Dual ifgMosaic: A Versatile Method for Multispectral and Combinatorial Mosaic Gene-Function Analysis. Cell 170,800-814.e18.

Posfai, E., Petropoulos, S., de Barros, F.R., Schell, J.P., Jurisica, I., Sandberg, R., Lanner, F., and Rossant, J. (2017). Position- and Hippo signaling-dependent plasticity during lineage segregation in the early mouse embryo. 6 .

Quinlan, A.R., and Hall, I.M. (2010). BEDTools: a flexible suite of utilities for comparing genomic features. Bioinformatics 26, 841-842. 
Rada-Iglesias, A., Bajpai, R., Swigut, T., Brugmann, S.A., Flynn, R.A., and Wysocka, J. (2011). $A$ unique chromatin signature uncovers early developmental enhancers in humans. Nature 470, 279-283.

Ralston, A., and Rossant, J. (2008). Cdx2 acts downstream of cell polarization to cellautonomously promote trophectoderm fate in the early mouse embryo. Dev. Biol. 313, 614-629.

Ralston, A., Cox, B.J., Nishioka, N., Sasaki, H., Chea, E., Rugg-Gunn, P., Guo, G., Robson, P., Draper, J.S., and Rossant, J. (2010). Gata3 regulates trophoblast development downstream of Tead4 and in parallel to Cdx2. Development 137, 395-403.

Ran, F.A., Hsu, P.D., Wright, J., Agarwala, V., Scott, D.A., and Zhang, F. (2013). Genome engineering using the CRISPR-Cas9 system. Nat. Protoc. 8, 2281-2308.

Rayon, T., Menchero, S., Nieto, A., Xenopoulos, P., Crespo, M., Cockburn, K., Canon, S., Sasaki, H., Hadjantonakis, A.K., de la Pompa, J.L., et al. (2014). Notch and hippo converge on $\mathrm{Cdx2}$ to specify the trophectoderm lineage in the mouse blastocyst. Dev Cell 30,410422.

Rayon, T., Menchero, S., Rollán, I., Ors, I., Helness, A., Crespo, M., Nieto, A., Azuara, V., Rossant, J., and Manzanares, M. (2016). Distinct mechanisms regulate Cdx2 expression in the blastocyst and in trophoblast stem cells. Sci. Rep. 6 .

Rivron, N.C., Frias-Aldeguer, J., Vrij, E.J., Boisset, J.-C., Korving, J., Vivié, J., Truckenmüller, R.K., van Oudenaarden, A., van Blitterswijk, C.A., and Geijsen, N. (2018). Blastocyst-like structures generated solely from stem cells. Nature 557, 106-111.

Robinson, M.D., McCarthy, D.J., and Smyth, G.K. (2010). edgeR: a Bioconductor package for differential expression analysis of digital gene expression data. Bioinformatics 26, 139-140.

Russ, A.P., Wattler, S., Colledge, W.H., Aparicio, S.A., Carlton, M.B., Pearce, J.J., Barton, S.C., Surani, M.A., Ryan, K., Nehls, M.C., et al. (2000). Eomesodermin is required for mouse trophoblast development and mesoderm formation. Nature 404, 95-99.

Russell, R., Ilg, M., Lin, Q., Wu, G., Lechel, A., Bergmann, W., Eiseler, T., Linta, L., Kumar P., P., Klingenstein, M., et al. (2015). A Dynamic Role of TBX3 in the Pluripotency Circuitry. Stem Cell Reports 5, 1155-1170.

Saiz, N., Kang, M., Schrode, N., Lou, X., and Hadjantonakis, A.-K. (2016). Quantitative Analysis of Protein Expression to Study Lineage Specification in Mouse Preimplantation Embryos. J. Vis. Exp. 53654.

Samarage, C.R., White, M.D., Alvarez, Y.D., Fierro-Gonzalez, J.C., Henon, Y., Jesudason, E.C., Bissiere, S., Fouras, A., and Plachta, N. (2015). Cortical Tension Allocates the First Inner 
Cells of the Mammalian Embryo. Dev Cell 34, 435-447.

Sasaki, H. (2015). Position- and polarity-dependent Hippo signaling regulates cell fates in preimplantation mouse embryos. Semin. Cell Dev. Biol. 47-48, 80-87.

Schindelin, J., Arganda-Carreras, I., Frise, E., Kaynig, V., Longair, M., Pietzsch, T., Preibisch, S., Rueden, C., Saalfeld, S., Schmid, B., et al. (2012). Fiji: an open-source platform for biological-image analysis. Nat. Methods 9, 676-682.

Schwanbeck, R. (2015). The Role of Epigenetic Mechanisms in Notch Signaling During Development. J. Cell. Physiol. 230, 969-981.

Senner, C.E., Krueger, F., Oxley, D., Andrews, S., and Hemberger, M. (2012). DNA methylation profiles define stem cell identity and reveal a tight embryonicextraembryonic lineage boundary. Stem Cells 30, 2732-2745.

Shi, S., Stahl, M., Lu, L., and Stanley, P. (2005). Canonical Notch signaling is dispensable for early cell fate specifications in mammals. Mol Cell Biol 25, 9503-9508.

Shin, T.H., Brynczka, C., Dayyani, F., Rivera, M.N., and Sweetser, D.A. (2016). TLE4 regulation of wnt-mediated inflammation underlies its role as a tumor suppressor in myeloid leukemia. Leuk. Res. 48, 46-56.

Slack, J.M.W. (2002). Conrad Hal Waddington: the last Renaissance biologist? Nat. Rev. Genet. 3, 889-895.

Souilhol, C., Cormier, S., Tanigaki, K., Babinet, C., and Cohen-Tannoudji, M. (2006). RBPJkappa-dependent notch signaling is dispensable for mouse early embryonic development. Mol Cell Biol 26, 4769-4774.

Souilhol, C., Perea-Gomez, A., Camus, A., Beck-Cormier, S., Vandormael-Pournin, S., Escande, M., Collignon, J., and Cohen-Tannoudji, M. (2015). NOTCH activation interferes with cell fate specification in the gastrulating mouse embryo. Development 142, 36493660 .

Sprinzak, D., Lakhanpal, A., LeBon, L., Santat, L.A., Fontes, M.E., Anderson, G.A., GarciaOjalvo, J., and Elowitz, M.B. (2010). Cis-interactions between Notch and Delta generate mutually exclusive signalling states. Nature 465, 86-90.

Steptoe, P.C., Edwards, R.G., and Purdy, J.M. (1971). Human blastocysts grown in culture. Nature 229, 132-133.

Stirparo, G.G., Boroviak, T., Guo, G., Nichols, J., Smith, A., and Bertone, P. (2018). Integrated analysis of single-cell embryo data yields a unified transcriptome signature for the human pre-implantation epiblast. Development 145, dev158501.

Strumpf, D., Mao, C.A., Yamanaka, Y., Ralston, A., Chawengsaksophak, K., Beck, F., and 
Rossant, J. (2005). Cdx2 is required for correct cell fate specification and differentiation of trophectoderm in the mouse blastocyst. Development 132, 2093-2102.

Sulston, J.E., Schierenberg, E., White, J.G., and Thomson, J.N. (1983). The embryonic cell lineage of the nematode Caenorhabditis elegans. Dev. Biol. 100, 64-119.

Suwińska, A., Czołowska, R., Ożdżeński, W., and Tarkowski, A.K. (2008). Blastomeres of the mouse embryo lose totipotency after the fifth cleavage division: Expression of $\mathrm{Cd} 2 \mathrm{2}$ and Oct4 and developmental potential of inner and outer blastomeres of 16- and 32-cell embryos. Dev. Biol. 322, 133-144.

Symmons, O., and Spitz, F. (2013). From remote enhancers to gene regulation: charting the genome's regulatory landscapes. Philos. Trans. R. Soc. B Biol. Sci. 368, 2012035820120358.

Tabansky, I., Lenarcic, A., Draft, R.W., Loulier, K., Keskin, D.B., Rosains, J., Rivera-Feliciano, J., Lichtman, J.W., Livet, J., Stern, J.N., et al. (2013). Developmental bias in cleavage-stage mouse blastomeres. Curr Biol 23, 21-31.

Tanaka, S., Kunath, T., Hadjantonakis, A.K., Nagy, A., and Rossant, J. (1998). Promotion of trophoblast stem cell proliferation by FGF4. Science (80-. ). 282, 2072-2075.

Tarkowski, A.K. (1959). Experiments on the Development of Isolated Blastomeres of Mouse Eggs. Nature 184, 1286-1287.

Tarkowski, A.K., and Wroblewska, J. (1967). Development of blastomeres of mouse eggs isolated at the 4- and 8-cell stage. J Embryol Exp Morphol 18, 155-180.

Tarkowski, A.K., Wroblewska, J., Tarkowski, B.K., and \J. (1967). Development of blastomeres of mouse eggs isolated at the 4- and 8-cell stage. J Embryol Exp Morphol 18, 155-180.

Tinevez, J.-Y., Perry, N., Schindelin, J., Hoopes, G.M., Reynolds, G.D., Laplantine, E., Bednarek, S.Y., Shorte, S.L., and Eliceiri, K.W. (2017). TrackMate: An open and extensible platform for single-particle tracking. Methods 115, 80-90.

Torres-Padilla, M.E., Parfitt, D.E., Kouzarides, T., and Zernicka-Goetz, M. (2007). Histone arginine methylation regulates pluripotency in the early mouse embryo. Nature 445, $214-$ 218.

Totaro, A., Castellan, M., Battilana, G., Zanconato, F., Azzolin, L., Giulitti, S., Cordenonsi, M., and Piccolo, S. (2017). YAP/TAZ link cell mechanics to Notch signalling to control epidermal stem cell fate. Nat. Commun. 8, 15206.

Totaro, A., Castellan, M., Di Biagio, D., and Piccolo, S. (2018). Crosstalk between YAP/TAZ and Notch Signaling. Trends Cell Biol. 28, 560-573. 
Toyooka, Y., Oka, S., and Fujimori, T. (2016). Early preimplantation cells expressing Cdx2 exhibit plasticity of specification to TE and ICM lineages through positional changes. Dev Biol 411, 50-60.

Tun, T., Hamaguchi, Y., Matsunami, N., Furukawa, T., Honjo, T., and Kawaichi, M. (1994). Recognition sequence of a highly conserved DNA binding protein RBP-J kappa. Nucleic Acids Res. 22, 965-971.

Ungefroren, H., Gieseler, F., Kaufmann, R., Settmacher, U., Lehnert, H., and Rauch, B. (2018). Signaling Crosstalk of TGF- $\beta / A L K 5$ and PAR2/PAR1: A Complex Regulatory Network Controlling Fibrosis and Cancer. Int. J. Mol. Sci. 19, 1568.

VanDussen, K.L., Carulli, A.J., Keeley, T.M., Patel, S.R., Puthoff, B.J., Magness, S.T., Tran, I.T., Maillard, I., Siebel, C., Kolterud, A., et al. (2012). Notch signaling modulates proliferation and differentiation of intestinal crypt base columnar stem cells. Development 139, 488497.

de Vries, W.N., Binns, L.T., Fancher, K.S., Dean, J., Moore, R., Kemler, R., and Knowles, B.B. (2000). Expression of Cre recombinase in mouse oocytes: A means to study maternal effect genes. Genesis 26, 110-112.

Waghray, A., Saiz, N., Jayaprakash, A.D., Freire, A.G., Papatsenko, D., Pereira, C.-F., Lee, D.F., Brosh, R., Chang, B., Darr, H., et al. (2015). Tbx3 Controls Dppa3 Levels and Exit from Pluripotency toward Mesoderm. Stem Cell Reports 5, 97-110.

Wamaitha, S.E., and Niakan, K.K. (2018). Human Pre-gastrulation Development. In Current Topics in Developmental Biology, pp. 295-338.

Wang, W.C.H., and Shashikant, C.S. (2007). Evidence for positive and negative regulation of the mouse Cdx2 gene. J. Exp. Zool. Part B Mol. Dev. Evol. 308B, 308-321.

Wang, H., Zang, C., Liu, X.S., and Aster, J.C. (2015). The Role of Notch Receptors in Transcriptional Regulation. J. Cell. Physiol. 230, 982-988.

Watanabe, T., Biggins, J.S., Tannan, N.B., and Srinivas, S. (2014). Limited predictive value of blastomere angle of division in trophectoderm and inner cell mass specification. Development 141, 2279-2288.

Watanabe, Y., Miyasaka, K.Y., Kubo, A., Kida, Y.S., Nakagawa, O., Hirate, Y., Sasaki, H., and Ogura, T. (2017). Notch and Hippo signaling converge on Strawberry Notch 1 (Sbno1) to synergistically activate Cdx2 during specification of the trophectoderm. Sci Rep 7, 46135.

Wennekamp, S., Mesecke, S., Nédélec, F., and Hiiragi, T. (2013). A self-organization framework for symmetry breaking in the mammalian embryo. Nat. Rev. Mol. Cell Biol. 14, 452-459.

Wicklow, E., Blij, S., Frum, T., Hirate, Y., Lang, R.A., Sasaki, H., and Ralston, A. (2014). HIPPO 
Pathway Members Restrict SOX2 to the Inner Cell Mass Where It Promotes ICM Fates in the Mouse Blastocyst. PLoS Genet. 10, e1004618.

Wieschaus, E. (2016). Positional Information and Cell Fate Determination in the Early Drosophila Embryo. In Current Topics in Developmental Biology, pp. 567-579.

Wu, G., Gentile, L., Fuchikami, T., Sutter, J., Psathaki, K., Esteves, T.C., Araúzo-Bravo, M.J., Ortmeier, C., Verberk, G., Abe, K., et al. (2010). Initiation of trophectoderm lineage specification in mouse embryos is independent of Cdx2. Development 137, 4159-4169.

Wu, J., Huang, B., Chen, H., Yin, Q., Liu, Y., Xiang, Y., Zhang, B., Liu, B., Wang, Q., Xia, W., et al. (2016). The landscape of accessible chromatin in mammalian preimplantation embryos. Nature 534, 652-657.

Xenopoulos, P., Kang, M., Puliafito, A., Di Talia, S., and Hadjantonakis, A.-K. (2015). Heterogeneities in Nanog Expression Drive Stable Commitment to Pluripotency in the Mouse Blastocyst. Cell Rep. 10, 1508-1520.

Yadav, T., Quivy, J.-P., and Almouzni, G. (2018). Chromatin plasticity: A versatile landscape that underlies cell fate and identity. Science 361, 1332-1336.

Yagi, R., Kohn, M.J., Karavanova, I., Kaneko, K.J., Vullhorst, D., DePamphilis, M.L., and Buonanno, A. (2007). Transcription factor TEAD4 specifies the trophectoderm lineage at the beginning of mammalian development. Development 134, 3827-3836.

Yamaji, M., Seki, Y., Kurimoto, K., Yabuta, Y., Yuasa, M., Shigeta, M., Yamanaka, K., Ohinata, Y., and Saitou, M. (2008). Critical function of Prdm14 for the establishment of the germ cell lineage in mice. Nat. Genet. 40, 1016-1022.

Yamaji, M., Ueda, J., Hayashi, K., Ohta, H., Yabuta, Y., Kurimoto, K., Nakato, R., Yamada, Y., Shirahige, K., and Saitou, M. (2013). PRDM14 Ensures Naive Pluripotency through Dual Regulation of Signaling and Epigenetic Pathways in Mouse Embryonic Stem Cells. Cell Stem Cell 12, 368-382.

Yang, J., Gao, C., Chai, L., and Ma, Y. (2010). A Novel SALL4/OCT4 Transcriptional Feedback Network for Pluripotency of Embryonic Stem Cells. PLoS One 5, e10766.

Yee, S.P., and Rigby, P.W. (1993). The regulation of myogenin gene expression during the embryonic development of the mouse. Genes Dev. 7, 1277-1289.

Yimlamai, D., Christodoulou, C., Galli, G.G., Yanger, K., Pepe-Mooney, B., Gurung, B., Shrestha, K., Cahan, P., Stanger, B.Z., and Camargo, F.D. (2014). Hippo pathway activity influences liver cell fate. Cell 157, 1324-1338.

Ying, Q.-L., Wray, J., Nichols, J., Batlle-Morera, L., Doble, B., Woodgett, J., Cohen, P., and Smith, A. (2008). The ground state of embryonic stem cell self-renewal. Nature 453, 519523. 
Ziomek, C.A., and Johnson, M.H. (1980). Cell surface interaction induces polarization of mouse 8-cell blastomeres at compaction. Cell 21, 935-942. 
This thesis includes a CD with the following information:

- Appendix 1: Table with differentially expressed genes (DEG) obtained after the RNA-seq analysis in control and Rbpj mutant morulae.

- Appendix 2: Table with differentially expressed genes (DEG) that have an RBPJ consensus binding site included in an open chromatin ATAC-seq peak in a $10 \mathrm{~Kb}$ window surrounding the gene.

- Movie 1: Time lapse imaging of a mouse embryo from the CBF1-VENUS line during morula to blastocyst transition.

- Movie 2: 3D reconstruction of a mouse embryo from the CBF1-VENUS line after live imaging during morula to blastocyst transition. 


\section{PUBLICATIONS}

The work described in this thesis is included in the following preprint:

Menchero S., López-Izquierdo A., Rollan I., Sainz de Aja J., Andreu MJ., Kang M., Adan J., Benedito R., Rayon T., Hadjantonakis AK., Manzanares M. (2018) Transitions in cell potency during early mouse development are driven by Notch. bioRxiv doi: https://doi.org/10.1101/451922

During the development of the thesis, the following reviews have been published:

Menchero S., Sainz de Aja J., Manzanares M. (2018) Our First Choice: Cellular and Genetic Underpinnings of Trophectoderm Identity and Differentiation in the Mammalian Embryo. Curr Top Dev Biol 128:59-80

Menchero S., Rayon T., Andreu MJ., Manzanares M. (2017) Signaling pathways in mammalian preimplantation development: Linking cellular phenotypes to lineage decisions. Dev Dyn 246(4):245-61

The collaboration in other research projects during the development of the thesis has resulted in the following publications:

Sainz de Aja J., Menchero S., Rollan I., Barral A., Tiana M., Jawaid W., Cossio I., Alvarez A., Carreño-Tarragona G., Badia-Careaga C., Nichols J., Göttgens B., Isern J., Manzanares M. The pluripotency factor Nanog controls primitive hematopoiesis and directly regulates Tal1. (In revision for EMBO J).

Rayon T.*, Menchero S. ${ }^{*}$, Rollán I., Ors I., Helness A., Crespo M., Nieto A., Azuara V., Rossant J., Manzanares M. (2016) Distinct mechanisms regulate $C d \times 2$ expression in the blastocyst and in trophoblast stem cells. Sci Rep 6:27139. [* Equal contribution]

Rayon T., Menchero S., Nieto A., Xenopoulos P., Crespo M., Cockburn K., Canon S., Sasaki H., Hadjantonakis A.K., de la Pompa J.L., Rossant J., Manzanares, M. (2014) Notch and Hippo converge on $\mathrm{Cd} \times 2$ to specify the trophectoderm lineage in the mouse blastocyst. Dev Cell 30(4):410-22. 

